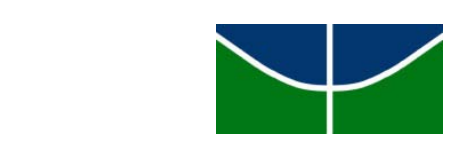

UNIVERSIDADE DE BRASÍLIA

Instituto de Ciências Humanas

Departamentode História

Programa de Pós-graduação em História

Guilherme Oliveira Lemos

A HISTORIOGRAFIA SOBRE CONGO E ANGOLA DO SÉCULO XVI AO XVIII Refletindo a partir dos Estudos Africanos e Pós-Coloniais 
Guilherme Oliveira Lemos

A HISTORIOGRAFIA SOBRE CONGO E ANGOLA DO SÉCULO XVI AO XVIII

Refletindo a partir dos Estudos Africanos e Pós-Coloniais

Dissertação apresentada ao Programa de PósGraduação em História, do Departamento de História do Instituto de Ciências Humanas da Universidade de Brasília, como requisito parcial para a obtenção do título de Mestre em História.

Orientador: Anderson Ribeiro Oliva 
Guilherme Oliveira Lemos

\section{A HISTORIOGRAFIA SOBRE CONGO E ANGOLA DO SÉCULO XVI AO XVIII \\ Refletindo a partir dos Estudos Africanos e Pós-Coloniais}

Dissertação apresentada ao Programa de PósGraduação em História, do Departamento de História do Instituto de Ciências Humanas da Universidade de Brasília, como requisito parcial para a obtenção do título de Mestre em História.

Aprovada em de março de 2016.

BANCA EXAMINADORA

Prof. Dr. Anderson Ribeiro Oliva - HIS/UnB

(Presidente)

Prof. Dr. Leandro Santos Bulhões de Jesus - UNICEUB

(Membro)

Prof. Dr. Wanderson Flor Nascimento- FIL/UnB

(Membro) 


\section{AGRADECIMENTOS}

A todos os que me precederam e são partes indissociáveis dessa jornada: meus avós, meus pais, meus ancestrais. A minha avó Eustáquia, cuja determinação e paixão pelo ensino cultivou uma família de educadores. A minha mãe pelos ensinamentos que transpassam as barreiras da universidade. A meu pai pelo incentivo, desde muito cedo, nos caminhos da história.

Aos professores e professoras. Ao Anderson Oliva pela paciência, orientação e indicação dos textos sobre estudos africanos e pós-colonialidade. A Teresa Kirschner pelas contribuições em teoria e metodologia da história. A PatrícioBatsîkama e Carlos Almeida que disponibilizaram suas obras com toda prestatividade.

Aos amigos e colegas. Em especial a Mariana Mesquita pela presença de antes e o incentivo que ainda persiste no agora. A Claudio Dantas, pelo empréstimo do computador sem o qual não conseguiria vencer essa batalha. A Scarlett Dantas, amiga inseparável desde o primeiro semestre de graduação. A Tiago Rodrigues, Lucas Farage, Lucas Facó, Lucas Marques, Daniel Ramos, Manuela Leda, Maurício Piatti, Cecília Siqueira, Rafael Nascimento, Alan Aruil, Regis Marques e tantos outros queridos das Ciências Sociais e da História que compartilharam, nas festas ou intervalos fora da biblioteca, os dramas da vida e da academia.

A toda família do Tumba NzoJimonna Dia Nzambi. Principalmente a Francisco Aires (Tata ria NkisiNgunzetala) e Márcio Sanchez (Tata NdengeMutawamê) pelo cuidado, aconselhamento e suporte. A Christinano Granja (Tata MuxiLembá) pela revisão ortográfica e formatação deste texto. A Perla Ribeiro (MakotaMenhaTalala), Elaine Quirino (KotaKawajinan), Douglas Pinheiro (Kayanguzu), David Hissa (Kindele), Higor Faria (Lumbozauamê), Flávio Souza (Kwendaiungo), AishaDiéne (LembáMueji), Tiago Ferreira 
(Nvulakenan) e Taíssa Dias (MakotaZumbaianga) por compartilharem alguns dos meus momentos mais importantes dentro e fora dessa Nzo.

A todos vocês o meu mais sincero agradecimento com carinho e amor.

Turilakotandungejakotajavula. 

"O Homem é movimento em direção ao mundo e ao seu semelhante. Movimento de agressividade que engendra a escravização ou a conquista; movimento de amor, de doação de si, ponto final daquilo que se convencionou chamar de orientação ética. Qualquer consciência é capaz de manifestar, simultânea e alternativamente, essa duas componentes."

Frantz Fanon,Pele Negra, Mascaras Brancas. 


\section{RESUMO}

A historiografia sobre Congo e Angola do século XVI ao XVIII frequentemente utilizou os relatos de missionários que vivenciaram a região nesse período, principalmente a história mais “tradicional” das décadas de 1940 e 1950. Durante a década de 1960 essas fontes deixaram de receber atenção devido à história oral que despontava no ambiente acadêmico como forma de reescrever uma história africana que falasse por si. Mas, rapidamente na década de 1970 e 1980 a historiografia volta-se mais uma vez para esses registros na tentativa de recriar uma percepção sobre o passado. Desde então, o modelo interpretativo que prevaleceu consistia em limpar as poeiras do etnocentrismo dessas narrativas a fim de deixar mais nítidos os elementos históricos da fonte. Recentemente, porém, surgem outras vias de interpretação para os registros missionários considerando suas descrições sobre o "espírito volátil” dos africanos como sendo, no fundo, um sintoma da rigidez e plasticidade dos próprios sistemas cosmológicos centro-africanos. Estudamos as diferentes abordagens historiográficas buscando compreender como esses sucessivos modelos teórico-metodológicos competem por uma melhor descrição da alteridade africana. Ao mesmo tempo em que circunscrevemos as formas pelas quais são operados e construídos os saberes sobre África.

Palavras-Chave: Historiografia; Congo; Angola; epistemologia; estudos africanos; póscolonialidade. 



\begin{abstract}
The historiography of Congo and Angola between sixteenth-eighteenth century often used the reports of missionaries who experienced on region in this period, especially the "traditional" history of the 1940s and 1950. Among the 1960s these sources don't left received attention because of the to oral history that was rising in the academics studies as a way to rewrite an African history to speak for itself's. But, in the 1970s and 1980s the historiography turns back, once more, to these records in an attempt to recreate a perception about the past. Since then, the interpretative model who prevailed has consisted in attempting to clean the dust of the ethnocentrism of these narratives in order to make clearer the historical elements of the source. Recently, however, rise other ways of interpretation the missionaries records considering his descriptions about the "volatile spirit" of Africans as being, in essence, a symptom of rigor and plasticity of the own cosmological systems in Central African systems.We have studied the different historiographical approaches trying to understand how these successive theoric-methodological models are competing for a better description of the African alterity. At the same time while we contain the roles in which they have controlled and built the knowledge about Africa.
\end{abstract}

Key words: Historiography; Kongo; Angola; epistemology; Afrian studies; postcoloniality. 



\section{SUMÁRIO}

INTRODUÇÃO

1 AS BASES EPISTEMOLÓGICAS DO AFRICANISMO NA HISTÓRIA E NA ANTROPOLOGIA 14

1.1 A não-história de "povos estacionados no tempo" 15

1.2 África: de uma história da raça para as marcas de um passado em comum. 26

1.3 Historiografia africanista como disputa colonial: justificativa e deslegitimação. 34

\section{PANORAMA DO DESENVOLVIMENTO DA HISTORIOGRAFIA SOBRE CONGO}

E ANGOLA: 1966-2013.

2.1 Birmingham: a desintegração política dos reinos mbundu pelo comércio escravista português.

2.2 Anne Hilton: uma análise das instituições políticas através da cosmologia bakongo. 49

2.3 James Sweet e a coexistência de múltiplas identidades religiosas. 53

2.4 Patrício Batsîkama, o resgate das instituições políticas pré-coloniais 58

3 JAN VANSINA, JOHN THORNTON E CARLOS ALMEIDA: OS SUCESSIVOS DEBATES TEÓRICO-METODOLÓGICOS. 61

3.1 Jan Vansina: entre história e antropologia 63

3.2 John Thornton: as inflexões herdadas do estruturalismo braudeliano 
3.3 Carlos Almeida e a reflexão do habitus nos processos endógenos entre africanos e europeus... 88

CONSIDERAÇÕES FINAIS 96

REFERÊNCIAS BIBLIOGRAFICAS 100 


\section{INTRODUÇÃO}

Sabemos as complicações e as dificuldades de se fazer uma história da história, ou aquilo que nós comumente classificamos como um trabalho historiográfico. Não apenas por repetirmos um árduo caminho, feito durante os longos anos da graduação, analisando e refletindo as diferentes perspectivas de autores sobre um mesmo assunto. Mas também porque, ao fazermos, perdemos contato com o objeto primeiro de nossa atenção - seja ele a África Central do século XVII, os intercursos transatlânticos, o comércio de seres humanos no século XVIII ou o impacto do cristianismo nas cosmologias bakongo e mbundu - que nos atraía justamente pela sua distância em relação ao tempo e ao espaço, ou proximidade na constituição identitária enquanto sujeito. Apesar disso, os estudos em historiografia africana se revelam uma alternativa frutífera para a compreensão e síntese das abordagens temáticas, conceituais e epistêmicas sobre as diversas vertentes seguidas pelos especialistas. E, também, dispõe aos interessados uma gama de opções bibliográficas revisitadas ou inovadoras sobre os mais diversos assuntos.

Para além disso, a complexidade da construção de um texto em historiografia reside na dificuldade de articular locais, experiências e influências vivenciadas pelos autores. Afinal, como bem mostrou Michel de Certeau, a operação histórica "se refere à combinação de um lugar social, de práticas 'científicas' e de uma escrita”․․ Ela tem um lugar social que é o do próprio historiador. Quando se escreve e pesquisa, reinterpreta-se o passado sob a ótica das suas experiências sócio-históricas do presente e expectativas futuras. Com efeito, os estudos africanos mais recentes têm elucidado as posições da história, da antropologia, da sociologia e da filosofia. Essas pesquisas compreendem o entrelaçar das bases epistemológicas de cada uma dessas ciências e como elas serviram e foram servidas do poder-saber colonial. Afinal,

\footnotetext{
${ }^{1}$ Certeau, A escrita da História, p. 47.
} 
documentar a diferença constitui um paradoxo: por um lado, aparenta reconhecimento; por outro, constitui um juízo moral que singulariza o mundo do Outro para revelar como em nada é parecido com o do Mesmo².

Apesar da diversidade de ideias, as elucidações dos estudos africanos são quase sempre acompanhadas de um questionamento: “quão africanos são os chamados estudos africanos?”3, questão que permeia de alguma forma esse trabalho, uma vez que nossa pretensão é compreender a história da África (especificamente do Congo e de Angola entre os séculos XVI e XVIII) produzida majoritariamente por não-africanos, mas além disso, uma história da África tida como referência e que guarda nos seus pilares teóricos as inflexões de uma epistemologia eurocêntrica ${ }^{4}$.

Daí a impossibilidade de se escrever sem enunciar os locais dos autores, quer em um ambiente micro como as instituições acadêmicas ou num ambiente macro como a própria nação e as configurações sociais mais complexas. Algumas vezes falhamos no nosso ofício enquanto historiógrafos por não encontrarmos materiais suficientes para relacionar com as produções. Não foi o caso de Vansina, que têm dois livros sobre suas memórias de vida acadêmica, mas foi o de Anne Hilton, da qual muito pouco se sabe a respeito. Aliás, analisar o trabalho dos historiadores exige esforço na percepção dos indícios teóricos que levaram à formulação de suas respectivas teses e nem sempre esses rastros são explícitos.

De tal modo, o centro da nossa investigação são alguns trabalhos históricos produzidos entre 1960 e 2010. Essa historiografia lançou seus olhos sobre Congo e Angola por diversos motivos, ora para condenar a colonização por uma via instrumentalista - se mostrando avessa à produção portuguesa da década de 1950 - ora para compreender como se deu a interação de africanos e europeus no contexto atlântico. Nosso objetivo foi identificar os

\footnotetext{
${ }^{2}$ Mbembe, Crítica da Razão Negra, p. 153.

${ }^{3}$ Hountondji, Conhecimento de África, conhecimento de Africanos: duas perspectivas sobre os Estudos Africanos, p. 151.

${ }^{4}$ Mudimbe, A Invenção de África, p. 36.
} 
esforços explicativos/descritivos sobre as possíveis circunstâncias e acontecimentos que tencionaram as transformações dessas populações, além de identificar uma relação entre pressupostos teóricos e propostas de metodologia para análise das fontes. Para isso, fizemos um largo uso das críticas produzidas pelos estudos africanos e/ou pós-coloniais, aproveitando as ponderações sobre as bases epistemológicas das ciências sociais e humanas no ocidente.

Durante a pesquisa identificamos um primeiro movimento entre os historiadores que produziram seus textos na década de 1960. Metodologicamente a questão girava em torno de “como produzir conhecimento histórico relevante sobre as sociedades africanas que não deixaram registros históricos?”. A resposta veio com o desenvolvimento de um método histórico através da oralidade, seguido do resgate dos vestígios escritos de viajantes que permaneceram na região - especialmente, os textos deixados pelas missões católicas no Congo e em Angola no século XVII. Ao final da década de 1970, entretanto, outras perguntas se colocaram diante dos historiadores: “como extrair as informações necessárias dos vestígios deixados por missionários, mas que contém muito dos preconceitos e imagens que desqualificam o Outro? Como esses vestígios contribuem para a construção da história dessas populações sendo elas as próprias protagonistas?”.

Cremos que tanto as perguntas formuladas pelos historiadores quanto as respostas dadas para cada uma delas possibilitam compreender os caminhos discursivos, teóricos e metodológicos desses trabalhos. Se assim conseguirmos, revelaremos as relações da produção historiográfica como saber-podercom as configurações sociais em que se inscrevem.

Quando do levantamento das fontes, encontramos a princípio cerca de $50^{5}$ produções entre teses, dissertações, artigos, capítulos, entrevistas e livros dentro do recorte proposto. Esses textos passaram por uma primeira leitura de modo que, ao final, foram selecionados 14

\footnotetext{
${ }^{5}$ Para a seleção desses trabalhos foram usadas as seguintes bases de dados: http://www.jstore.com, http://memoria-africa.ua.pt/introduction/tabid/83/language/pt-PT/Default.aspx, $\quad$ http://www.scielo.br/, http://scholar.google.com.br/, http://journals.cambridge.org/action/login, $\quad$ http://www.bce.unb.br/, http://www6.senado.gov.br/sicon/index.jsp\#. Além de consulta na Biblioteca Central de Estudos Africanos da ISCTE-IUL na cidade de Lisboa em fevereiro de 2015.
} 
seguindo os seguintes critérios: a) que indicavam reflexões teóricas; b) obras de historiadores norte-americanos e europeus ${ }^{6}$; c) que utilizaram relatos missionários como fontes estruturantes na argumentação do trabalho ed) que debatem relações cosmológicas entre o cristianismo e a cosmologia bakongo. Durante esse processo tivemos em mente as seguintes questões: quais são as bases teóricas? Quais são as fontes, metodologias e categorias de análise utilizadas? Como são entendidas as “representações” do universo angolano e congolês feitas pelos missionários? De que forma esses trabalhos dialogam entre si? Como se relacionam com a época em que foram escritos e seus locais de produção?

Feito essa seleção, dividimos a escrita em três capítulos. O primeiro discute as bases epistemológicas da história e da antropologia, refletindo como a África se insere como marca primeira da alteridade desde a fundação dessas ciências. Essas problematizações foram pensadas a partir de AchilleMbembe, Valentim-Yves Mudimbe, KwameAppiah, Paul Gilroy e outros teóricos dos estudos africanos e pós-coloniais. Apesar de não existir uma unanimidade no pensamento, esses autores evidenciaram como as bases das ciências humanas estão fundadas num racionalismo europeu do século XVIII, criador de um humanismo que subhumaniza outras formas de ser, de pensar, de viver e de se relacionar no mundo. Discursos tão impactantes capazes de perpassar dos idealizadores do pan-africanismo ao marxismo dos movimentos de libertação.

Depois, no segundo capítulo construímos um panorama da historiografia sobre Congo e Angola dos séculos XVI ao XVIII. Para isso, selecionamos os trabalhos de David Birmingham, Anne Hilton, James Sweet e Patrício Batsîkama. A intenção foi apresentar como esses estudos se desenvolveram de 1960 a 2010, selecionando exemplos pontuais para demonstrar as diferentes perspectivas em relação às mudanças ocorridas nessas regiões.

\footnotetext{
${ }^{6}$ Apenas as obras de Patrício Batsîkama escapam desse critério, elas são apresentadas no Capítulo 2 para revelar a recente produção de uma história feita por e para o Congo e Angola. Gostaríamos de deixar registrado nosso agradecimento pessoal ao autor pela disponibilidade e prontidão no fornecimento dessas obras.
} 
Por fim, no último capítulo, fizemos uma análise crítica das obras de Jan Vansina, John Thornton e Carlos Almeida, autores que também discorreram sobre Congo e Angola na era moderna. Esses nomes foram selecionados para um estudo mais detalhado pois apresentam um embate marcante na relação entre suas bases teóricas e métodos para a leitura dos registros missionários. Enquanto Vansina desenvolve o método da história oral, Thornton resgata as fontes missionárias descartando o eurocentrismo e Almeida expõe a necessidade de analisá-las por um todo nos seus contextos.

Perceber esses meandros é algo importante principalmente para aqueles que tencionam trilhar pesquisas sobre a história africana. Esperamos no futuro que o trabalho forneça aos leitores, principalmente os graduandos em história, um material de caráter críticopanorâmico para situá-los de alguma maneira nas discussões sobre historiografia referente ao Congo e Angola, África e estudos africanos. 


\section{AS BASES EPISTEMOLÓGICAS DO AFRICANISMO NA HISTÓRIA E NA}

\section{ANTROPOLOGIA}

A produção de conhecimento sobre África, com a metodologia daquilo que se convencionou chamar "rigor científico", se confunde com o desenvolvimento das ciências humanas na Europa e nos Estados Unidos entre os finais do século XIX e início do século XX. Enquanto produção de conhecimento humano, esses estudos também se confundem com os acontecimentos de sua época, que moldavam não apenas as experiências desses cientistas, mas também as expectativas em torno de si mesmos e de seus objetos (no caso, as populações do continente africano).

Um século antes, nos finais do XVIII e início do XIX, as concepções eurocêntricas em relação aos africanos já se apresentavam em postulados que iriam moldar grande parte da estrutura epistemológica ocidental como nos pensamentos de Kant e Hegel. E, se continuássemos a saga dessa arqueologia do saber ${ }^{7}$ sobre África, conseguiríamos encontrar nos textos da antiguidade ideias distorcidas sobre os homens africanos. Não é esse o nosso papel aqui, uma vez que outros já o fizeram com maior destreza ${ }^{8}$. Nesse primeiro momento, cujo propósitoé uma análise mais geral sobre a historiografia africana, gostaríamos apenas de retomar textos pontuais produzidos no auge da modernidade e da contemporaneidade ${ }^{9}$ que de alguma maneira contribuíram para uma ideia geral de África. Refletiremos sobre esses postulados modernos comotextos basilares do desenvolvimento das ciências humanas,

\footnotetext{
${ }^{7}$ Foucault, Arqueologia do Saber, pp. 153-158.

${ }^{8}$ Mudimbe, A Ideia de África, pp. 103-141. ; Oliva, Da Aethiopia à África, pp. 3-10.

${ }^{9}$ Os conceitos de modernidade e contemporaneidade são objetos de revisão constante. Na história tradicional, ou mesmo para alguns teóricos mais recentes, os marcos da modernidade são sempre eurocentrados. Por exemplo, por mais que Koselleck considere os contatos Atlânticos como parte do que constituirá a cisão de um "horizonte de expectativa” pautado no passado, é apenas na Revolução Francesa que esse rompimento se dá de fato, possibilitando um "pensamento moderno" voltado para o futuro, onde o "profectus" foi substituído pelo "progressus"; ver: Koselleck, Futuro Passado, pp. 305-327. Por outro lado, autores pós-coloniais como Mbembe centralizam a modernidade no complexo escravagista Atlântico, "canal expresso para a constituição do capitalismo moderno”; ver: Mbembe, Crítica da Razão Negra, pp. 34; 90.
} 
paraconsequentemente, adentramos nos meandros das configurações disciplinares da história e da antropologia.

\subsection{A não-história de “povos estacionados no tempo”.}

Como tem destacado Paul Gilroy, a modernidade não é apenas o palco em que surge a relação entre capitalismo, industrialização e democracia. É também o local do pensamento sistêmico de raça, onde em meio à relação entre conhecimento e poder as "verdades da raça" foram formuladas concomitantemente às reflexões sobre "individualidade, subjetividade, ontologia, tempo, verdade e beleza” ${ }^{10}$. É certo que o conceito já existia em períodos anteriores, mas ele ganhou um caráter distinto nessa ocasião por alinhar talentos e aspectos morais à natureza das fronteiras nacionais e raciais. Como bem identificou Gilroy analisando uma citação de Kant em Observações sobre o Sentimento do Belo e do Sublime:

Os negros da África não têm por natureza nenhum sentimento acima do trivial. O Sr. Hume desafia qualquer um a citar um único exemplo em que um negro tenha mostrado talentos, e afirma que entre centenas de milhares de negros que são transportados dos seus países para outros lugares, embora muitos tenham sido colocados em liberdade, ainda assim nenhum jamais foi encontrado que apresentasse qualquer coisa de grande em arte ou ciência ou qualquer outra qualidade digna de elogio, apesar de que entre os brancos alguns sempre se elevam bem acima das massas mais ínfimas, e por meio de dotes superiores ganham o respeito do mundo. A diferença entre estas duas raças de homens é tão fundamental quanto parece ser grande a diferença em matérias de capacidades mentais e de cor. ${ }^{11}$

A afirmação de Kant não elimina toda humanidade das populações negras, apenas confere um lugar e uma posição mais ínfima entre outros homens, sub-humaniza todos aqueles que compartilham as duas características indicadas logo de início: negro e africano.

\footnotetext{
${ }^{10}$ Gilroy, Entre Campos, p.79.

${ }^{11}$ Kant, apud, idem, p. 82.
} 
Nesse princípio de pensamento racialista confluem as características morais e naturais dos povos que, segundo Gilroy, brotam em outros textos frequentemente ignorados por estudiosos contemporâneos, “talvez porque os julguem como embaraçosos ou mesmo comprometedores das valiosas aspirações democráticas com as quais o Kant crítico também contribuiu com uma expressão duradoura”12.

Essas fórmulas de pensamento racialista germinadas já em finais do século XVIII e que associam o negro ao seu "lugar natural” - a África - são localizadas tanto em discursos filosóficos como poéticos. Utilizando exemplos pontuais para então conceber ideias gerais sobre a "natureza dos africanos", Sade e Bocage elaboraram leituras da famosa NzingaMbandi, rainha de Matamba e do Ndongo, que havia perpetrado o imaginário europeu através dos relatos de viagem do missionário Giovanni Cavazzi. Como identificou o historiador Luiz Felipe Alencastro ${ }^{13}$, no cronista francês a rainha aparece como o ser “extremamente delicado [...] que põe em movimento todos os recursos da maldade" 14 ao decapitar seus amantes após gozá-los. No poeta português a imagem da soberana negra surge para depreciar seu desafeto por Caldas Barbosa, o então presidente da Academia dos Renascidos em Lisboa, pelo fato de sua mãe ter nascido em Angola ${ }^{15}$. Mas é, sobretudo, num compendio de aulas de Hegel que o reinado de Nzinga e seus "horrores" surgem para extrair conclusões gerais sobre o negro, os quais em "suas consciências não chegaram ainda a uma intuição de nenhuma objetividade" ${ }^{16}$.

De acordo com Mbembe, essa condição de infra-humanidade que confunde o africano com o ser feroz desenrola-se em dois eixos no ideal metropolitano. Primeiro justifica o empreendimento colonial como fundamental na ação civilizadora de ajudar e proteger esses seres "sem lei”. Depois, ao segmentar e inventar esse mundo distante, apresentando como

\footnotetext{
${ }^{12}$ Gilroy, Entre Campos, p. 83.

${ }^{13}$ Alencastro, O Trato dos Viventes, pp.280-281.

${ }^{14}$ Sade, A Filosofia na Alcova, p. 83.

${ }^{15}$ Bocage, Poemas, p. 102-103.

${ }^{16}$ Hegel, Lecciones Sobre la Filosofia de Historia Universal, p. 187
} 
reais aspectos muitas vezes idealizados, criou-se um conhecimento imaginado. E se existe um objeto e um lugar onde são dadas as sustentações da relação entre imaginado e economia ficcional que faz ver um modo mais distinto e bestial "é exatamente esse signo ao qual se chama Negro e, por tabela, o aparente não-lugar a que chamamos África e cuja característica é ser [...] o indício de uma ausência de obra”17.

Chegamos ao ponto desejado: África, o lugar sem obra, incapaz de produzir história e mudanças significativas no tempo. As visões eurocêntricas de Hegel sobre o passado e a natureza africana condenavam também, na sua dialética, o futuro dessas humanidades, “eram e serão o que sempre foram”. Na mesma época surge a divisão entre história e pré-história, pontuada no advento ocidental da escrita, que também dividia os povos letrados e não letrados e, assim, desconsiderava qualquer possibilidade de produção histórica por meio da oralidade. Portanto, a África “não era um continente histórico”.

Mesmo assim, alguma ciência sobre essas sociedades poderia (ou deveria) ser formulada. E não por acaso observamos no final do século XIX o crescente interesse sobre África. Na Era Imperialista houve um grande acúmulo de conhecimentos sobre as etnias, línguas, os costumes e as religiões desse Outro. E, como os estudos africanos têm apontado desde a década de 1980 por meio dos trabalhos de Mbembe, Mudimbe, Appiah, Hountondji e outros, estes conhecimentos estavam intimamente ligados à manutenção de um poder confluente nas formas materiais e comportamentais. No saber ocidental sobre África, era preciso desenvolver conhecimentos acerca da geografia, dos domínios e das possibilidades de exploração material ${ }^{18}$. Mas também era preciso hierarquizar, segmentar e separar "espécies humanas” e, consequentemente, condenar aqueles que receberam uma classificação racial a

\footnotetext{
${ }^{17}$ Mbembe, Crítica, p. 30.

${ }^{18}$ Difuila, Historiografia da História de África, p. 54.
} 
"habitar essa separação como se fosse o seu verdadeiro ser, odiando aquilo que é, para tentar ser aquilo que não é.”19

Assim definiram-se os objetos de cada disciplina de acordo com seus parâmetros metodológicos. À história cabia calar-se diante daquilo que para ela não existia - um passado não documentado ou pessoas que não produziam mudanças significativas no tempo. Não existia a possibilidade de produção de conhecimento histórico para África, somente era vislumbrado o passado ou a presença europeia em África. Por outro lado, coube à antropologia o estudo das “diferenças naturais”, fenotípicas e morais entre os seres humanos, atenta apenas aos "selvagens” que carregavam em si a memória de um passado antiguíssimo do "primitivo" e do homem natural que não havia se transformado no tempo. E por mais diversos que fossem os “etnocentrismos" no interior dos discursos científicos, eles eram essencialmente reducionistas. “Eles não falam de África nem dos africanos, mas antes justificam o processo de inventar e conquistar um continente designando seu primitivismo ou desordem[...]”20 . Ao final, da cisão dos objetos específicos a cada uma dessas ciências, nasce um casamento “frutífero” em questão de dominação, sub-humanização e racialização da imagem ou da vida concreta dos sujeitos analisados.

A África e os africanos surgem como objeto antropológico no mesmo momento da delimitação desse campo investigativo e do contexto das investidas coloniais, ou melhor, poderíamos dizer que a antropologia só surge para tentar provar os "tempos outros" e “naturezas outras” apontados pela filosofia europeia do século XVIII. Como destaca o historiador Joseph Miller, “a primeira fase da antropologia investigativa em África, foi fruto do idealismo alemão e não recebeu pouco do romântico ímpeto europeu de uma promessa de sociedade capitalista industrializada do fin de siècle»"21. Essa fase orientou um grupo de etnologistas germânicos que distinguiam a humanidade entre sociedades "avançadas”, em

\footnotetext{
${ }^{19}$ Mbembe, Crítica, p. 67.

${ }^{20}$ Mudimbe, A Invenção de África, p. 38

${ }^{21}$ Miller, History and Africa/Africa and History, p.3.
} 
termos de tratados culturais, daquelas sociedades ou grupos que consideravam "primitivos", sendo defensores da ideia de que todos os produtos de “civilização” de outras partes do mundo foram difundidos a partir de um único centro: o antigo Oriente Médio e a Europa. Baseados nessa hipótese, procuravam construir uma "história” significante da África através do que se julgava como próximo da civilidade. O etnógrafo alemão Leo Frobenius se tornou o exemplo dessa busca para a uma história da África. Seu estudo convertia o antigo mito camita da bíblia cristã em um novo, com uma linguagem científica, na qual os europeus pudessem reconhecer em África vestígios de uma civilização ${ }^{22}$.

Essas produções tiveram impacto significativo na primeira historiografia sobre África produzida por norte-americanos na viragem do século XIX para o XX, mas faremos essa análise mais adiante. Mantendo o foco na África como objeto antropológico, damos um pequeno salto para o período entre 1920 e 1960, entendido por Bruno Reinhardt como “período clássico” da antropologia, “marcado pela institucionalização da disciplina na Europa e nos Estados Unidos” ${ }^{23}$. Naquele momento, o funcional-estruturalismo e o relativismo cultural são as principais vertentes metodológicas na antropologia e também foram analisados por Mudimbe em A Ideia de África. Esses dois autores desvelam como "natureza africana” e “disparidade de tempos” foram utilizadas pela antropologia e serviram às manutenções do poder-saber colonial.

Os anos entre 1930 e 1950, momento do auge das relações entre colonialismo e antropologia, também são balizados historicamente pela Segunda Guerra. Alguns estudiosos entendem, inclusive, que existe nesse momento uma revisão dos conceitos que contribuíram para os efeitos perniciosos da experiência fascista e nazista na Europa ${ }^{24}$. Paradoxalmente,

\footnotetext{
${ }^{22}$ Miller, History and Africa/Africa and History, p. 4.

${ }^{23}$ Reinhardt, Poder, história e coetaneidade, p. 332.

${ }^{24}$ Bruno Reinhardt faz uma leitura diferenciada sobre essa revisão dos conceitos nas ciências sociais das décadas de 1930-1950, se opondo à Adam Kuper que entende uma mudança significativa no funcional-estruturalismo com a chegada de Radcliffe-Brown (1937), ver: Reinhardt, op. cit., p. 334. Por outro lado, na historiografia existe uma tendência em tratar os Annales como os impulsionadores de uma "revolução" na escrita da história,
} 
entretanto, as relações das estruturas acadêmicas ocidentais com outros lugares do globo seguiam a tônica colonial. Na antropologia esse efeito é sintomático, por exemplo, em dois eventos. Primeiro pelo vinculo que a “antropologia prática” de Malinowski fazia com os governos britânicos em África. Depois, pelo apoio financeiro da Fundação Rockfeller ao InstituteofAfricanLanguagesandCultures (1932) que poderia fornecer conhecimentos úteis sobre as sociedades africanas aos administradores coloniais.

Mas, mais do que isso, essa relação é dada nos discursos dos estudos antropológicos tanto nas obras de Malinowski como nas de Radcliffe-Brown e Evans-Pritchard ${ }^{25}$.

O argumento de Reinhardt, que se dispôs à análise desses trabalhos, funda-se no entendimento da antropologia moderna marcada por "uma série de estratégias de alienação temporal, mais óbvias em sua fase evolucionista, mas igualmente observáveis em suas vertentes funcionalista, culturalista e estruturalista”"26. Consequentemente essa “alienação temporal” impunha aos “estacionados" no tempo a necessidade de mudança rumo à modernidade, mesmo a antropologia se afastando do evolucionismo enquanto norteador das análises. Por exemplo, o foco de Malinowski era os "nativos em mudança” e não os “selvagens intocados”, ou seja, interessava o estudo daqueles que tiveram algum contato com o mundo "civilizado". Isso implicava na negligência da temporalidade do Outro e levava em consideração apenas um regime de historicidade, o europeu ${ }^{27}$.

Nesse contexto, a famosa escola britânica funcional-estruturalista se manteve centrada em duas áreas: antropologia política e religião. A intenção era encontrar a função que as tradições exerciam dentro das sociedades que as perpetuavam, uma representação coletiva de um passado estático, o que eles denominaram “mito”. No caso das tradições orais, por

e tomado essa visão, historiógrafos africanistas têm enxergando ai a abertura de portas para as pesquisas sobre África, ver: Burke, A Revolução Francesa da historiografia, p. 20; Barbosa, Eurocentrismo, História e História da África, p. 50. Mais adiantes tentaremos recompor essa ideia mostrando que o surgimento dos estudos africanos estavam mais ligados às questões coloniais.

${ }^{25}$ Reinhardt,Poder, história e coetaneidade, p. 333-334.

${ }^{26}$ Idem, op. cit., p. 331.

${ }^{27}$ Idem, op. cit., p. 334. 
exemplo, interessava mais a função social, reguladora e política que aquela tradição exercia e menos seu papel enquanto relato das alternâncias dessa mesma sociedade no tempo. Havia dois problemas na postura do funcional-estruturalismo no cerceamento do tempo africano, como diz Reinhardt:

[...] primeiro, o apagamento da agência africana em nome de arranjos estruturais, claramente representada pela apatia nativa assumida pela domesticação conceitual do "político" em África; segunda, a imposição de limites conceituais que desmembram as práticas locais em domínios ontológicos distintos, logo ignorando a historicidade dos agentes e seus próprios horizontes semânticos regulatórios. ${ }^{28}$

Entre 1940 e 1950 essa vertente antropológica enfrentou críticas e autocríticas. Ao assumir a cadeira de antropologia em Oxford no ano de 1946, Evans-Pritchard demonstrava uma inquietude flertando com várias frentes disciplinares ${ }^{29}$. Isso de algum modo refletia não só a crise das ciências sociais como o início do fim da hegemonia do funcional-estruturalismo. Poderíamos dizer ainda que a escolha de Evans-Pritchard não foi ao acaso, visto que era considerado o mais aberto às análises conjunturais por acompanhar os trabalhos historiográficos ${ }^{30}$. Por outro lado, surgia também a escola de Manchester com duras críticas ao modelo malinowskiano de "contato cultural” e que convertia as diferenças culturais entre africanos e colonos brancos em um "sistema socioeconômico único, que integra desigualmente ambos os grupos a uma ordem capitalista englobante” ${ }^{31}$. Assim a antropologia britânica mantinha as noções estruturais nas suas bases epistemológicas.

Porém, as contribuições mais importantes à antropologia na época foram consequências das lutas por independências em África, principalmente após a independência

\footnotetext{
${ }^{28}$ Reinhardt, Poder, tempo e coetaneidade, pp.338-339.

${ }^{29}$ Idem, op. cit., p. 341.

${ }^{30}$ Burke, A Escola dos Annales, p. 163.

${ }^{31}$ Reinhardt, op. cit., p. 341.
} 
de Gana em $1957^{32}$. Não satisfeitos em desvelar a face vil do imperialismo europeu nas suas consequências materiais, os nacionalismos africanos atacaram também as bases ideológicas desses sistemas. Contudo, as vias utilizadas por esses nacionalismos estavam também, através da dialética marxista, embebidas das bases teóricas que impunham a necessidade da aproximação dos tempos; ou seja, era necessário superar o atraso promovido pelo capitalismo europeu, tornando-se uma sociedade mais “evoluída” e igualitária ${ }^{33}$.

Todas essas estratégias de controle do tempo, ou melhor, de “administração da coetaneidade” 34 foram fundamentais na manutenção da hegemonia europeia sobre África. O que as recentes pesquisas têm apontado é que, mesmo nos períodos mais “revisionistas” dos estudos antropológicos, pode-se identificar as imposições de tempos seccionados. A consequência dessa postura não é apenas a imposição da necessidade de mudança rumo aos modelos mais desenvolvidos, ela se estende para a negação da capacidade de autogestão dessas sociedades. Assim, explica Reinhardt:

Oscilando entre uma temporalidade do não mais...não ainda, o colonialismo funcionou por uma lógica paradoxal, baseada na promessa e no adiantamento da coetaneidade, uma de suas heranças duradouras para a sociedade pós-colonial africana. ${ }^{35}$

Claramente, as disputas temporais na antropologia são chaves importantes na composição do saber-poder colonial, mas certamente não são as únicas. Mudimbe faz ver - no marxismo africano, no relativismo de Herskovits ou na etnofilosofia - outros artifícios desses saberes derivados da ideia de "natureza africana”.

Ainda na década de 1950, assistiu-seà fusão de várias disciplinas (economia, geografia, história) da qual brotou um novo campo de estudo africanista. A proximidade

\footnotetext{
${ }^{32}$ Idem, op. cit, p.343.

${ }^{33}$ Reinhardt, Poder, tempo e coetaneidade, pp. 342-346; Mudimbe, A Ideia de África, pp. 65-101.

${ }^{34}$ Idem, op. cit., p.353.

${ }^{35}$ Idem, op. cit., p. 354.
} 
epistemológica dessas disciplinas facilitou essa união, apesar de estarem separadas em seus objetivos e métodos. Todavia, concernente ao objeto “África”, elas se viram numa difícil situação: as necessidades de libertação no continente, a qualificação de suas cientificidades e as bases filosóficas de suas sustentações ${ }^{36}$. Dificuldades desveladas e apontadas muito recentemente pelos estudos africanos.

Nesse contexto, a figura africana era um fato empírico, entendida, experimentada e exaltada como a marca da alteridade. Isso decorria da ânsia da antropologia, da história e outras disciplinas na busca pela verdade. E, consequentemente, seus resultados “formaram-se sobre critérios de afirmação da verdade sobre África e da sua tradução em discursos cientificamente credíveis”37. E mais, utilizavam empiria para atestar a verdade dos discursos teóricos. Acerca do tema,Mudimbe se esforça em perceber as consequências dessas posturas para os estudos africanistas.

Em sua concepção, o marxismo africano, enquanto epistemologia escatológica, buscava uma verdade objetiva proveniente do discurso sobre o homem. Muito desse discurso ignorou a complexidade de suas bases enquanto epistemologia "eliminando assim os paradoxos do seu discurso e da sua prática”38 ${ }^{38}$ Disso resultava um passado de África mítico, um porvir que não se concretizou devido às imposições capitalistas do colonialismo. Em todo caso, tornou-se um passado e uma história apagando-se as histórias, e a ideia de África tornou-se um grande futuro não concretizado. Mesmo assim, Mudimbe não nega a importância do marxismo africano na sua insistência da relação entre prática das ciências sociais e política. Sua crítica gira mais ao redor das consequências e os custos desastrosos em África, observáveis em uma série de governos controlados por essas figuras do marxismo africano. No entanto, a gênese do fracasso estaria nas bases das concepções epistemológicas e, com efeito, os desdobramentos podem ser identificados não só no marxismo, mas também

\footnotetext{
${ }^{36}$ Mudimbe, A Ideia de África, p. 65.

${ }^{37}$ Idem, op. cit., p. 64.

${ }^{38}$ Idem, op. cit., p. 69.
} 
no relativismo cultural de referência em Herskovits ${ }^{39}$. Deixaremos o marxismo para mais tarde quando abordarmos seus desdobramentos na historiografia e manteremos a atenção no relativismo cujo impacto é sintomático na antropologia.

Nesse último caso, a busca da verdade se dava por via empírica, ou seja, a realidade determina a credibilidade e a objetividade do discurso, alicerçado em um princípio de trabalho acadêmico que evocava curvas relativistas do sujeito pesquisador, imaginando a possibilidade de suspender seus preconceitos para chegar à objetividade de um conhecimento sobre a alteridade. A década de 1950, nos dizeres de Mudimbe estava “caracterizada pelo predomínio dos modelos reducionistas na antropologia" 40 . Uma simplificação que utilizava a "tradição africana” para responder as limitações da história, operada concomitantemente aos usos dos conceitos negritude, personalidade negra, autenticidade.

Essas intenções ficam mais evidentes no método propostos por Herskovits, como bem destacou Mudimbe ao citar um trecho da obra Cultural Relativism:

Como método, o relativismo cultural engloba o princípio da nossa ciência (ou seja, a antropologia) segundo o qual, no estudo de uma cultura, procura-se alcançar o maior grau de objetividade possível; não julgar os modos de comportamento que são objeto de descrição, nem tentar alterá-los. Na realidade, pretende-se compreender as sanções do comportamento em termos das relações estabelecidas no seio da própria cultura, abstendo-se de interpretações baseadas num quadro de referência pré-concebido. O relativismo enquanto filosofia incide sobre a natureza dos valores culturais e ainda sobre as implicações de uma epistemologia emanante de um reconhecimento do poder do condicionamento. Os seus aspectos práticos incluem a aplicação prática - dos princípios filosóficos resultantes do método, num panorama mais alargado e transcultural do mundo. ${ }^{41}$

Mas em que consistem os resultados desse relativismo empático sobre o Outro? Era precisamente uma fusão, uma "identificação com o outro de tal ordem que culminava na

\footnotetext{
${ }^{39}$ Melville Jean Herskovits foi o antropólogo norte-americano orientando de Franz Boas cuja obra mais relevante foi Cultural Relativism.

${ }^{40}$ Mudimbe, A Ideia de África, p.76.

${ }^{41}$ Herskovits, Cultural Relativism, p. 57, apud.,Mudimbe, A Ideia de África, p.75.
} 
transformação nesse outro (pelo menos, uma vez)»"42. Daí afiguram-se dois grandes problemas: por um lado, a negação do Eu que pressupõe o real conhecimento do Outro; e por outro, entender o homem como um dado objetivo da ciência justificado pela história e a dinâmica cultural ${ }^{43}$. Assim, para conhecer o Homem foi preciso estabelecer variedades culturais, as semelhanças e dessemelhanças e com isso a antropologia persistiu na razão etnológica.

Mudimbe mostra também como esses efeitos foram sintomáticos na concepção de “arte primitiva”, através da pergunta "em que momento os objetos trabalhados africanos se tornaram objetos de arte?”44. Houve uma mudança de percepção acerca dos objetos africanos enquanto arte que perpetuou a ideia de uma "natureza africana” imutável e perene presente nos artesanatos. Seguiremos essa perspectiva de análise do filósofo durante nosso trabalho. Contudo, sem abordar os efeitos na concepção de arte africana, lançaremos os olhares para os efeitos dessa epistemologia relativista e de verdade única, e consequentemente de "natureza africana”, na escrita de uma história da África.

Diante dessas colocações sobre os desdobramentos dos discursos sobre África na antropologia, podemos pensar ainda num paralelo com a história - constituída como prática de pesquisa desde o século XIX e inscrita no ambiente acadêmico ocidental. Um recorte e um olhar mais apurado sobre esse campo disciplinar se justifica por três motivos: a) pelo poder que a escrita da história possui na constituição das identidades e que, como consequência, nos casos de ausência da intersubjetividade histórica, ela seja capaz de gerar relações morais assimétricas na vida prática dos $\operatorname{sujeitos}^{45}$; b) a relativa ausência, no âmbito brasileiro, de reflexões acerca da historiografia africana despontada recentemente apenas com exemplos pontuais, como é o caso da concisa pesquisa de Muryatan Barbosa; c) e, por fim, o ascendente

\footnotetext{
${ }^{42}$ Idem, op. cit., pp. 76-77.

${ }^{43}$ Mudimbe, A Ideia de África, p. 76.

${ }^{44}$ Idem, op. cit., p. 95.

${ }^{45}$ Rüsen, Narratividade e objetividade nas ciências históricas, p. 68
} 
número de estudos sobre história da África que, em âmbito nacional, decorre de um processo das lutas dos movimentos negros que desembocou nos últimos anos na Lei 10.639/03.

Deste modo, ao observar esses pontos, há a necessidade de perguntarmos a nós mesmos (historiadores ocidentais de África) até que ponto perpetuamos e seguimos visões históricas acerca dos africanos que, além de essencializá-los, exclui sua própria voz por meio da pretensa posição relativa ao “objeto”. Ou seja, ainda historicisamos a África sem fazermos uma crítica à epistemologia europeia? É uma pergunta que talvez deva permear nossas mentes. Se assim for, corremos um grande risco de convocar uma voz e, no momento mesmo de a evocarmos, ela já "ser baralhada, reduzida ao silêncio e impedida de se exprimir na primeira pessoa do singular" ${ }^{46}$.

\section{2 África: de uma história da raça para as marcas de um passado em comum.}

Apesar da estigmatização em relação às impossibilidades de uma história da África com transformações significativas no tempo, ainda houve no século XIX empreendimentos pontuais no sentido de formular uma filosofia da história africana. Porém, essa narrativa era o constructo de uma única história, de um único povo e uma única raça rumo ao avanço que havia sido suspenso devido à degeneração causada pela escravidão, mergulhada, assim, nos preceitos metodológicos e epistemológicos das ciências humanas ocidentais de sua época.

Alexander Crummell (1819-1898) e W.E.B Du Bois (1868-1963) foram os maiores expoentes da idealização de história, ou melhor filosofia da história, do "povo negro”. Tidos como pais do pan-africanismo e partícipes de um período pós-escravocrata nos Estados Unidos, não há como negar a importância política desses nomes e suas influências tanto nas independências africanas como nos movimentos por direitos civis. Norte-americanos de

\footnotetext{
${ }^{46}$ Mbembe, Crítica da Razão Negra, p. 127.
} 
nascimento e, respectivamente, liberiano e ganês por adoção, ambos foram exemplos da diáspora no Atlântico. Recentemente, contudo, parte dos estudos africanos e pós-coloniais apontam para os usos dos conceitos de raça, nação e África inscritos nos trabalhos desses pensadores. Consideraremos pontualmente a vida de Crummell circunscrevendo suas análises sobre os tempos históricos de África para, depois, destacarmos a África de Du Bois como nação da raça negra, levando em conta a importância da noção de progresso na gênese do pan-africanismo estendida até sua fase mais marxista na metade do século $\mathrm{XX}^{47}$. As considerações feitas a seguir baseiam-se em parte das análises feitas por KwameAppiah e Paul Gilroy sobre esses dois expoentes do pan-africanismo. Assim, escolhemos também Crummell e DuBois pela riqueza de possibilidades de análises que a vida e obra desses autores proporciona para entender a difusão dos conceitos negro e África.

A formação de Crummell dirigiu de maneira categórica sua atuação política como abolicionista e pan-africanista. Pastor episcopal formado na Universidade de Cambridge, transitou em vários espaços do Atlântico. Após terminar seus estudos na Inglaterra, parte para a Libéria em 1853 e só retorna aos Estados Unidos em 1863 durante a Guerra de Secessão ${ }^{48}$. Suas referências não poderiam ser outras que não as literaturas clássicas britânicas, e como destacou Appiah, Crummell não tinha dúvidas que o inglês seria a língua superior capaz de salvar a Libéria ${ }^{49}$. Em Future ofAfrica (1863) - um compêndio de palestras e sermões reunidos na obra mais instigante de Crummell - as considerações acerca da importância civilizacional da língua inglesa aparecem no primeiro texto The EnglishLanguage in

\footnotetext{
47 Entendemos a noção de história em Crummell e Du Bois como filosofias da história, uma concepção da narrativa histórica orientada para o futuro, para o devir do homem negro, onde raça e nação cumpriram muito bem o seu papel no século XIX. As considerações que se seguem são decorrência das leituras dos trabalhos de KwameAppiah e Paul Gilroy. Veja: Appiah, Na casa de Meu pai, pp. 19-76.;Gilroy, O Atlântico Negro, pp. 223-280. No mundo europeu as críticas à filosofia da história foram construídas em grande parte no pósguerra por pensadores liberais combatentes do marxismo. Ver: Popper, The Porverty of Historicism, 1957; Löwith, Meaning in History: The Theological Implications of the Philosophy of History, 1949.

${ }^{48}$ Moses, Alexander Crummell A Study of Civilization and Discontent, pp. 119-145.

${ }^{49}$ Appiah, op. cit., pp. 19-20.
} 
Liberia $^{50}$. O título do livro, em si, já nos oferece um indício de como é pensada a história da África de Crummell, mas suas concepções ficam mais claras no sermão The ProgressCivilizationAlongthe West Coast ofAfrica ${ }^{51}$.

Mergulhado na miséria, o continente havia se degenerado durante os trezentos anos de sujeição tornando-se sinônimo de dor, "angústia, furto e assassinato" 52 . O ponto de partida de sua narrativa histórica é esse passado no subjuntivo, aquilo que poderia ter ocorrido se não fosse o cativeiro. Uma mancha tão potente que o problema de África “aparentava ser orgânico” e "quase impossível de mudar essa história num episódio de alegria, bênção e misericórdia” ${ }^{53}$. Entretanto, e paradoxalmente, existe uma organicidade na explicação de Crummell para problema da “incivilidade” africana: seu apartamento geográfico do mundo. O Saara, o grande mar de areia, havia separado por séculos a África do "mundo esclarecido", tornando suas populações tão incivilizadas quanto as ilhas recém-descobertas no Pacífico. Esse apartamento das grandes civilizações antigas reservou aos africanos as condições da idolatria, do paganismo e da incivilidade. Pobre África, “através de todas as eras, vem gerando e reproduzindo toda ninhada e progênie de superstições, idolatria e paganismo, através de todos os seus cômodos”54.

Nada obstante, a única saída para a escuridão do continente era primeiro com o fim da escravidão, mas depois e, sobretudo, o evangelho e as boas novas da salvação de Cristo. Na filosofia da história africana de Crummell o cristianismo era fator primordial de libertação da condição incivilizada.

Nessa dialética, a língua inglesa e o cristianismo eram mais que os catalisadores dessa transformação; na verdade, eram os únicos meios pelos quais a raça negra e o seu continente atingiriam o futuro de graça e misericórdia que, naquelas condições, só poderiam

\footnotetext{
${ }^{50}$ Crummell, op. cit., p. 9-54.

${ }^{51}$ Crummell, The Future of Africa, p. 101-129.

52 Idem, op. cit., p.105.

53 Idem, op. cit., p. 105.

${ }^{54}$ Idem, op. cit., p. 108.
} 
existir no subjuntivo e nas suposições. Por isso, a história de África deveria ser escrita para o porvir, seu passado não encontrava conexão com as realidades iluminadas das civilizações antigas e o grande lapso do desenvolvimento seria superado no exercício da graça divina.

Esse misto de filosofia da história cristã e civilidade é sintomático em Crummell apesar do conceito de raça ser menos articulado e, portanto, mais representativo - o que, de forma alguma, não exime a existência de alguma psicologia racial no pensamento crummelliano “que às vezes se manifesta como uma crença em modos de pensar caracteristicamente africanos” ${ }^{\text {55 }}$. Consequentemente, essa psicologia racial reforçou a crença de formas essenciais de pensamento africano e conteúdos próprios a esse pensamento. Apesar disso, não poderíamos ser injustos e afirmar que o pan-africanismo herdou exclusivamente de Crummell seu “racismo intrínseco”, uma vez que em sua época esse racismo era propriedade intelectual circulante no Ocidente. Seria mais sensato enxergá-lo como "um símbolo da influência desse racismo nos intelectuais negros, uma influência profundamente calcada na retórica do nacionalismo africano do pós-guerra” ${ }^{56}$.

Em relação a essa influência, poderíamos dizer o mesmo de Du Bois, cuja vida e obra foram extremamente extensas e impactantes no processo de construção do panafricanismo. No entanto, a concepção de Du Bois sobre raça era mais elaborada teoricamente do que a de Crummell - apesar desse conceito apresentar-se de várias maneiras ao longo da vida de Du Bois, chegando ao ponto de definir sua existência como a "autobiografia de um conceito de raça" ${ }^{57}$. Para explicação das condições negras, tanto em África como para além do Atlântico, ele tentou ultrapassar as ideias firmadas nas características físicas e concentrouse mais nas explicações sócio-históricas. Mas isso, contudo, não o eximiu de pensar nas divisões raciais e nos atributos que a "raça negra” poderia dar ao conhecimento universal.

\footnotetext{
${ }^{55}$ Appiah, Na Casa de Meu Pai, 48.

${ }^{56}$ Idem, op. cit., p. 41.

${ }^{57}$ Du Bois apud Appiah, Na Casa de Meu Pai, p. 53.
} 
Não devemos esquecer que Du Bois esteve no fluxo de historiadores norteamericanos que visitaram a Alemanha no final do século XIX. Estudou por dois anos na Universidade de Berlim (1892-1894) e foi impactado pelos ecos das notícias sobre as conquistas coloniais e as expedições científicas em África o que, anos depois, é sentido em textos como The Negro $(1915)^{58}$.

Nesse livro, Du Bois descreve os antigos reinos africanos sempre em comparação à civilização europeia. As glórias das primeiras realizações estavam cobertas pela recente exploração. Ele atribuía o fracasso africano à degeneração causada pelo sistema de escravidão imposto por europeus e árabes. Du Bois operava uma forma de pensamento racializado, justificando a degeneração do negro (enquanto conceito racial) por meio da escravidão, ou admitindo, como nos fez lembrar KwameAppiah, que "em nossos momentos mais calmos devemos reconhecer que os seres humanos se dividem em raças” ${ }^{\text {,59 }}$. Não obstante, mesmo reforçando o racialismo, Du Bois deu um passo à frente desvinculando, em alguma medida, as capacidades mentais humanas do fator biológico num artigo em 1911. E, enquanto se recusou aceitar a inferioridade negra, também operou o que Appiah chama de “dialética clássica na reação ao preconceito”. Assim, a diferença na concepção de Du Bois, portanto, “não está em que sua definição da raça discorde da científica: trata-se, antes, como exige a dialética, de que ele confere à raça uma importância moral e metafísica diferente da maioria dos seus contemporâneos brancos”60.

Por outro lado, na percepção de Du Bois as raças estavam destinadas a cumprir seu papel na história universal. E aqui, as influências do idealismo alemão e da filosofia da história são explícitas, ao ponto de apresentarem o negro norte-americano como “o sétimo povo da história do mundo, estendendo a lista de Hegel com um estilo retórico” ${ }^{61}$. Daí a

\footnotetext{
${ }^{58}$ Gilroy, O Atlântico Negro, pp. 245-280; Miller,History and Africa/Africa and History, p. 6.

${ }^{59}$ Du Bois apud Appiah, op. cit., p. 53.

${ }^{60}$ Appiah, Na Casa de Meu Pai, p. 55; 60-61.

${ }^{61}$ Gilroy, O Atlântico Negro, p. 263.
} 
necessidade de descobrir na civilização negra e no seu lugar de natureza (África) a mensagem intrínseca nas habilidades do seu povo. Como bem destacou Appiah, ele havia tido contato com a historiografia inglesa que explicava o espírito democrático norte-americano pelas experiências prévias das assembleias anglo-saxônicas; assim como fez leituras dos historiadores estadunidenses discutindo o espírito "latino” dos povos românicos. Logo, para ele, era extremamente cabível a história e a sociologia como observadora dos impulsos raciais. Mas o problema nessa ideia, assim como em outras concepções filosóficas da história, é conceber um futuro especulativo pautado no passado e justificado com análises históricas que partem do presente. Sendo assim:

Em todos esses textos [...] esses impulsos são supostamente descobertos como propriedades a posteriori dos grupos raciais e nacionais, não sendo critérios de pertença a eles. Na verdade é pelo fato de a alegação ser a posteriori que a comprovação histórica lhe é importante. $^{62}$

Assim, a história como instrumento de explicações lógicas justifica como Du Bois conseguiu, no decorrer de sua vida, rejeitar o discurso científico de raça em DuskofDawn $(1940)^{63}$ ao mesmo tempo em que manteve o pan-africanismo vivo. Afinal, “uma coisa é certa: desde o século XV, esses meus ancestrais e seus descendentes tiveram uma história comum”64. Essa história em comum, essa marca social da escravidão seria uma substituição da concepção biológica de raça? Seria "simplesmente sepultar a concepção biológica sob a superfície e não transcendê-la" ${ }^{65}$ ? Como veremos a seguir, essa passagem do conceito biológico para o sócio-histórico na construção de um projeto pan-africanista será por demais útil aos anseios do marxismo africano, cooptando as marcas da escravidão, da história comum e da negritude numa luta maniqueísta entre conquistados e conquistadores.

\footnotetext{
${ }^{62}$ Appiah, Na casa de meu pai, p.59.

${ }^{63}$ Idem, op. cit., p.68.

${ }^{64}$ Du Bois apud Appiah, op. cit., p.70.

${ }^{65}$ Appiah, op. cit., p. 70.
} 
Através dos movimentos de libertação, a partir da década de 1950, o marxismo se torna atrativo às realidades africanas como uma resposta ao colonialismo capitalista europeu. Divinizada nas suas promessas e evidente na vida concreta daqueles que sofriam estando na base da pirâmide, a dialética das classes parecia dar os instrumentos necessários para superar aquilo que a colonização deixou como rastro. As consequências do pensamento marxista em África foram políticas, ideológicas e de práticas. De algum modo, o marxismo conferiu inflexões conceituais aos estudos africanos e transformou gradualmente os objetivos e os métodos das ciências humanas e sociais que ganhavam um cunho militante.

Ao mesmo tempo, as lideranças políticas dos países em processo de libertação abraçavam as ideias marxistas seduzidas pelas promessas de sociedade igualitária. E nessa ilusão, reivindicaram o advento de um novo passado tradicional da nação, transformando pouco a pouco seus projetos políticos num desfio do marxismo que proclamavam instaurar. Consequentemente, por exemplo, “[...] o rigor materialista de Nkrumah foi acompanhado de uma das mais medíocres ditaduras políticas [...]” e “[...] a elegância das leituras de Marx e Engels realizadas por Senghor constituiu um simples objeto de exegeses sapientes orientadas para eruditos $[\ldots]^{\text {,66 }}$.

O que o marxismo em África revelou, assim como as teorias raciais de Du Bois, foi a vontade de tomar as rédeas da vida, de autonomia e de espanto ante a uma questão primeira: “somos todos iguais, também temos história”. Postura também identificada na geração de historiadores líderes do projeto História Geral da África (no caso, Joseph Ki-Zerbo, BethwellOgot e Cheick Anta Diop) que reivindicaram a inversão da pirâmide dentro das explicações históricas para o continente ${ }^{67}$ - os quais devemos prestar reconhecimento, menos pela postura epistemológica e mais pela intersubjetividade de seus questionamentos. A diferença é que para os historiadores ou pensadores marxistas africanistas, sejam eles

\footnotetext{
${ }^{66}$ Mudimbe, A Ideia de África, p. 71.

${ }^{67}$ Lopes, Pirâmide Invertida, p. 25.
} 
africanos ou não, a dialética anula o subjetivo em detrimento dos fatores objetivos e dessa forma "nem o acaso nem os riscos inerentes à condição dos indivíduos, membros singulares dessa classe, são história”68. Sem uma reflexão mais acurada sobre as bases do pensamento marxista, o próprio Marx se tornava um guia universal deixando gradualmente de ser um “europeu do século XIX”.

Por outro lado, tanto as análises marxistas gerais sobre o continentequanto as mais específicas sobre alguma região em África tiveram impactos sobre as visões de autodeterminação das sociedades africanas ${ }^{69}$. Enquanto o racialismo criou a separação do ser de si mesmo, gerando o sentimento de desapropriação naqueles que recebiam as alcunhas raciais e, assim, influindo na autodeterminação dos indivíduos de modo que eram obrigados a ser uma adulteração de si pelo outro, as análises marxistas contribuíram em conjunto na forja das ideias de desapropriação material por excelência, e portanto, o ser ficava preso aos fatores e às forças que escapavam de sua mão. Como bem destacou Mbembe, “esses dois gestos (a expropriação material e o empobrecimento ontológico) constituíram os elementos particulares da experiência negra e do drama que dela seria o corolário”70.

Quando a crítica marxista africana pensa o autogoverno, ela irá beber na fonte dos conceitos de "progresso" de uma modernidade alternativa. E, em meio à defesa do direito de autodeterminação na luta para reestabelecer o poder, surgem duas imagens dos negros africanos: de um lado o negro como "vontade sofredora”, imolado e ferido; e de outro, o negro como diferença cultural por princípio territorial. Essas imagens se tornaram o centro de um radicalismo nativista e desenrolam a história da África enquanto uma sequência infinita de

\footnotetext{
${ }^{68}$ Mudimbe, A Ideia de África, p. 73.

${ }^{69}$ Para o caso geral veja Walter Rodney, HowEuropeUnderdevelopedAfrica; no caso específico de Angola veja Birmingham, Trade andConflict in Angola.

${ }^{70}$ Mbembe, Crítica da Razão Negra, p. 140.
} 
infortúnios. Essa história de ciclos viciosos e fatalistas resumiu-se, ao final, na busca dos vilões e das vítimas ${ }^{71}$.

Ora, o problema história da adversidade infinita é justamente a impressão que se cria sobre os próprios africanos como indivíduos incapazes de pensar e de produzir conhecimento pela falta material. Se antes eles eram impossibilitados de um pensamento autônomo pelas barreiras raciais naturais, agora, eram pelos empecilhos da falta de universidades, de centros acadêmicos de excelência e do subdesenvolvimento imposto pelo colonialismo. Logo, suscitaremos na análise historiográfica uma questão que perpassa pelas consequências dessas visões: até que ponto nossas produções ocidentais sobre África carregam essa percepção sobre estudos africanos como materialmente incapazes de acrescentar conhecimento ao próprio continente?

Mais adiante, no Capítulo 2, suscitarei os impactos do marxismo na historiografia africanista e seus enlaces com a antropologia, o estruturalismo e a "longa duração" de Fernand Braudel,no Capítulo 3. Para isso, entretanto, precisamos pensar como a colocação de “novos” objetos e metodologias no fazer historiográfico europeu pouco se relaciona com uma nova perspectiva para a história da África na sua inscrição como agente ativo da história.

\subsection{Historiografia africanista como disputa colonial: justificativa e deslegitimação.}

Entre 1930 e 1950 a historiografia europeia sobre África se encontrava entre a justificativa e a deslegitimação para a ocupação dos territórios no continente. Afinal, assim como no caso antropológico ${ }^{72}$, a disputa por temporalidades e memórias de um local é dos poderes da história. E, como questiona Isabel Castro Henriques: "Quem, dispondo do poder,

\footnotetext{
${ }^{71}$ Idem, op. cit., p. 155-156.

${ }^{72}$ Cf. supra, p.7.
} 
deixará que sua imagem apareça deformada, insuficiente, caricatural ou viscosa?"”3 ${ }^{\text {. No caso }}$ da história portuguesa, a justificativa da ocupação de “seus territórios” coloniais era explicitada pela longa presença na região - argumento semelhante utilizado pela história militar espanhola para o norte da África ${ }^{74}$.

A vivência portuguesa da ideologia salazarista durante essas duas décadas influenciou e orientou as produções historiográficas sobre África. Numa proposta de raízes fincadas nas tendências anteriores dos objetivos coloniais, a disciplina foi usada e manipulada para justificar a exaltação do homem europeu e idealizar uma permanência anterior ao século XIX. Na criação de um passado “africano” que era, na verdade, a exaltação dos heróis portugueses e das conquistas militares, constitui-se um grupo de mitos estruturais do colonialismo português.

Analisando a História de Angola de Ralph Delgado, publicada em 1948, Henriques destaca três grupos de mitos: a) um primeiro grupo, cujas ideias eram pressupostos das missões civilizacionais e da superioridade congênita do homem branco; b) um segundo, que apontava o pioneirismo português nos descobrimentos além de evidenciar a presença lusa em África para mais dos quinhentos anos; e c) um terceiro grupo de mitos, identificado na influência de Gilberto Freyre e o seu luso-tropicalismo, mostrando como os portugueses “gentilmente” optaram pelo não uso da espada em favor do sexo e da miscigenação ${ }^{75}$.

Escrita num período de reforço da presença portuguesa em Angola e durante a Segunda Guerra, a obra é dedicada ao pai do autor - um antigo administrador colonial - e à comemoração do tricentenário da Restauração. Esses apontamentos indicavam como Angola só poderia ser explicada “com os portugueses e as famílias, com a nação e seu esforço civilizador multissecular” ${ }^{76}$. Nesse lusocentrismo a história de Angola só era possível a partir

\footnotetext{
${ }^{73}$ Henriques, A História da África e a reconstrução da visão do Outro, p. 48.

${ }^{74}$ Braudel, Les Espagnols et L'Afrique du Nord de 1492 a 1577, pp. 184-233.

${ }^{75}$ Henriques, A História da África e a reconstrução da visão do Outro, pp. 51-53.

${ }^{76}$ Idem, op. cit., p. 54.
} 
da presença portuguesa, como se houvessem desembarcado num território vazio e concedessem aos africanos “a honra de os submeter à escravatura primeiro, ao trabalho forçado depois!"

Sabemos, portanto, dos impactos dessa história usada como justificativa para a ocupação colonial: “estamos aqui há muito tempo, aqui devemos permanecer e somos todos luso-tropicais”. Mas, por outro lado, uma questão implícita permanece sem resposta: qual era, por exemplo, a intenção de historiadores como Fernand Braudel em deslegitimar a ocupação espanhola no Marrocos desde o século XV num artigo publicado em 1928, ou seja, no auge das disputas europeias por territórios em África logo após a Guerra do Rife?

A questão nasceu de outra que diz respeito à forma como historiógrafos tem colocado a escola dos Annales como revolucionária ${ }^{78}$, permitindo que outros, como Muryatan Barbosa, pontuem a maior visibilidade de África graças à tomada de consciência da necessidade de novos objetos e a inserção do continente nos espaços acadêmicos como fruto da Segunda Guerra ${ }^{79}$. Porém, como temos percebido nas páginas anteriores, não é a admissão da África como "novo” objeto das ciências humanas e sociais que coloca os indivíduos desse continente no centro da transformação de suas histórias. As lutas por independência teriam um fator muito mais decisivo tanto na maior consideração sobre o continente na academia europeia ${ }^{80}$ quanto na consideração dos africanos como agentes de sua história.

Pensar a história da África como consequência positiva de "um distanciamento gradual, mas decisivo, da historiografia do século XX em relação à historiografia tradicional

\footnotetext{
${ }^{77}$ Idem, op. cit., p.55.

${ }^{78}$ Burke, A Escola dos Annales, p. 20.

${ }^{79}$ Barbosa, África por ela mesma. p. 7.

${ }^{80}$ Assim como assistimos o crescente aumento de especialistas em cultura árabe depois do "11 de Setembro” e da "Guerra ao Terror” (no Brasil, por exemplo, o Programa de Pós-Graduação em Língua, Literatura e Cultura Árabe da USP recebeu aprovação da CAPES em dezembro de 2001 e começou a funcionar em 2002). É possível pensar o surgimento ou transformação dos institutos especializados em África durante os anos 1950 e 1960 relacionados aos conflitos coloniais. O próprio Bulletin de l'InstitutFrançais de AfriqueNoir que circulou com esse nome entre 1939-1965 tem suas heranças no passado colonial senegalês e, não por acaso, após a independência o seu nome é trocado para Bulletin de l'Institut Fundamental de AfriqueNoir em 1966. Ver: Gaillard, The Senegalese Scientific Comunity, p. 155-167.
} 
de cunho político-diplomático”81 é entrar num paradoxo. Afinal, se a renovação da história europeia e seu rompimento com a história tradicional "só foi consolidada a partir dos anos 1930”82, foi exatamente nessa década que o expansionismo urbano e colonial em África foi empreendido na sua maior amplitude ${ }^{83}$. Então, como não refletir sobre o poder da história, mesmo daquela que supõe ser mais inovadora, como criação de memórias e esquecimentos para a manutenção colonial?

LesEspagnolsetL'AfriqueduNord de 1492 a 1577 foi um dos primeiros artigos de Braudel, publicado na RevueAfricaine em 1928, durante os anos em que viveu na Argélia. As ideias seguem a tendência historiográfica francesa da época, ou seja, a crítica à histoireévénementielle de cunho militar-político bastante atacada pelos Annales. No começo do artigo Braudel afirma:

Podemos multiplicar esses exemplos e classificar, com algum excesso talvez, os historiadores da África espanhola em três categorias conforme estão dispostos, para estudar o detalhe dos eventos, sob o ponto de vista da Espanha, do Magrebe ou da história convencional. ${ }^{84}$

Durante todo o restante do texto ele se esforçara em mostrar como a história das campanhas espanholas no século XV em nada consistia num projeto duradouro de permanência na região. E ainda podemos perceber, assim como no exemplo da historiografia africanista portuguesa, um interesse maior na história das transformações europeias em África e muito menos nas configurações e transformações dos próprios atores sociais africanos. E, ao final, depois de demonstrar as derrotas e o contentamento da coroa espanhola apenas com Granada:

\footnotetext{
${ }^{81}$ Barbosa, op. cit., p.7.

${ }^{82}$ Idem, ibid.

${ }^{83}$ M'Bokolo, África Negra História e Civilizações - Tomo II, p. 500-518.

${ }^{84 ،}$ 'On pourrait multiplier ces exemples et classer, avec quelque excés parfois, les historiens de l'Afrique espagnole en trois catégories suivant qu'ils se sont placés, pour étudier le détail des événements, au point de vue de l'Espagne, du Maghreb ou de l'histoire générale” (Tradução: Helena Duarte). Braudel, Les Espagnols et L'Afrique du Nord de 1492 a 1577, p. 191.
} 
Os métodos militares espanhóis em África possuem assim pelas suas origens a marca da insuficiência dos meios empregados, da ignorância dos dirigentes, também revelam a força dos costumes adquiridos.

As consequências de tais métodos se mostram facilmente. No imenso país magrebino os Espanhóis não tiveram nenhuma influência séria. Economicamente o país lhes escapou, politicamente continuou submisso mais em aparência que na realidade, religiosamente permaneceu irredutivelmente hostil. ${ }^{85}$

Ou seja, o que Braudel faz é desmerecer a história nacionalista espanhola mostrando como as ocupações no norte africano eram insuficientes na economia, na política e na religião. Ora, a análise poderia passar despercebida ou interpretada como a crítica de um “homem para além do seu tempo” que já vislumbrava, em 1928, os erros do nacionalismo na historiografia espanhola. Mas as configurações sociais e políticas entre franceses e espanhóis no Marrocos no ano corrente da escrita do artigo não indicam esse caminho.

Nos fins de 1920 e durante os primeiros anos de 1930 a cidade de Tanger, entreposto comercial importante no nordeste marroquino, vivenciou uma tensão entre França e Espanha. Tanger estava sobre administração internacional desde 1923 e, desde 1912, 80\% do Marrocos era um protetorado francês com territórios possíveis para a exploração. Entre 1926 e 1928 houve grandes reivindicações de Madri e várias tentativas de incorporação da cidade como protetorado. Além disso, dois terços da população europeia no Tanger eram espanhóis, com motivos suficientes de ressentimento para com os franceses, colonos hegemônicos em relação aos espanhóis. A tensão se estendeu durante anos e o problema arrastou-se "a ponto de se converter numa tensão com Paris, apenas mitigada durante a II República»86. Caberia uma pesquisa mais aprofundada de como aconteceu essa reivindicação espanhola sobre Tanger

\footnotetext{
85، Les méthodes militaires des Espagnols en Afrique portentainsi par leurs origines la marque de l'insuffisance des moyensemployés, de l'ignorancedesmilieuxdirigeants, ellestrahissentaussila force deshabitudesacquises. Lesconséquences de tellesméthodes se devinentaisément. Surl'immensepaysmaghrébinlesEspagnols n'eurentaucuneinfluencesérieuse. Economiquementlepaysleuréchappa, politiquementil resta soumisplusenapparencequ'enréalité, religieusement ildemeurairréductiblementhostile.” (Tradução: Helena Duarte). Idem, op. cit., pp. 232,233.

${ }^{86}$ Vieira, O Império que Nunca Existiu, p. 190.
} 
(utilizando ou não o argumento da presença histórica para mais de séculos). Mas, as colocações até aqui feitas nos aproximam de um sentido: de um lado a Espanha insistindo na necessidade de aumentar seu domínio no Marrocos, de outro a França tentando manter sua hegemonia.

Nesse caso, o lugar de fala do historiador - francês residente na Argélia colonial durante as disputas europeias por territórios em África - revela em que medida a deslegitimação também pode servir para garantir os interesses nacionais. Ironicamente, Braudel, que viria a ser grande expoente dos Annales e crítico ferrenho de histórias nacionais e políticas, corre o risco de ser apontado com utilizador do poder da história para deslegitimar a ocupação espanhola por um lado, mas garantir a hegemonia francesa no Marrocos por outro.

Há, ainda, quem possa contra-argumentar, em defesa da escola francesa, que Braudel só constituiria seu corpo depois de 1938 e sua direção em $1947^{87}$ e por isso sua postura não poderia representar os Annales. Contudo, outros artigos publicados na revista nos anos 1930 e que versam sobre África são espantosamente de posição próxima, ou mais radicais. É o caso de Questionsafricaines, escrito em 1931 por Henri Labouret e André-É.Sayous, dividido em duas partes, cada uma sobre a responsabilidade respectiva destes autores ${ }^{88}$. Na primeira parte Labouret fica responsável por tratar da “África Negra”, ou seja, a região centro-sul do continente. O texto é muito mais uma resenha crítica dos trabalhos etnográficos da época com elogios sobre as análises feitas muita das vezes por comissários da colonização.

Já na segunda parte, vemos mais uma vez a questão marroquina levantada por Sayous. As considerações envolvem aspectos econômicos do protetorado francês na região e o autor apresenta soluções que dizem muito mais sobre o reforço das instituições e dos bancos

\footnotetext{
${ }^{87}$ Delacroix; Dosse\& Garcia, Correntes Históricas na França - Séculos XIX e XX, p.203.

${ }^{88}$ Labouret \& Sayous, Questions africaines, pp. 94-103.
} 
franceses. Ao final, para ele, o Marrocos exige ter uma via própria sob o protetorado francês. ${ }^{89}$

Os limites de uma amizade entre história africana e historiografia europeia ficam apontados nas nossas considerações, mas com certeza ainda necessitam de um estudo aprofundado. Contudo, essa política dos limites da amizade remete para uma antiga tradição francesa cujo objetivo é "pôr termo à hostilidade racial característica da consciência escravagista e da consciência do império" ${ }^{90}$. Mas, ao mesmo tempo, essa amizade tem duas faces. Na primeira ela é movida por uma lógica de universalização das condições de equidade e justiça, mas que não decorre de nenhuma relação de parentesco com o Negro. Pretende ser apenas uma amizade "de citação e apóstrofe"91 e exige ser uma relação de mutualidade com “obrigação de responder por eles” 92 .

Por outro lado, essa amizade é relação de “compaixão, de empatia e de simpatia perante o sofrimento de que os Negros foram vítimas" ${ }^{93}$. Logo, devido à sua inferioridade eles devem se adequar à escravatura e "a felicidade só pode ser atingida a serviço de um bom senhor”94. No caso acima a afirmação dos historiadores franceses é exatamente essa, “o Marrocos precisa de um bom senhor, apenas o protetorado francês é capaz disso”.

À luz das considerações dos estudos africanistas, sobretudo as de AchilleMbembe, vamos considerar nos capítulos seguintes essas relações entre o poder da história (enquanto conteúdo e disciplina acadêmica) e alertar para a necessidade da celebração da alteridade. Mas antes de chegarmos a esse ponto, nosso objeto historiográfico precisa ser desenhado e o capítulo 2 cumprirá esse papel. Apontaremos as obras históricas produzidas entre 1960 e 2000

\footnotetext{
89،"Le Maroc demande à avoir une vie propre sous le protectorat français.” (Tradução: Helena Duarte). Idem, op. cit., p. 103.

${ }^{90}$ Mbembe, Crítica da Razão Negra, p.132.

${ }^{91}$ Idem, ibid.

${ }^{92}$ Idem, ibid.

${ }^{93}$ Idem, ibid.

${ }^{94}$ Idem, op. cit., p.133.
} 
que versam sobre Angola e Kongo do século XVI, além de fazermos um apanhado de suas tendências analíticas e teóricas.

\section{PANORAMA DO DESENVOLVIMENTO DA HISTORIOGRAFIA SOBRE CONGO} E ANGOLA: 1966-2013.

As histórias de Congo e Angola são profundamente marcadas pelas interações ocorridas a partir do século $\mathrm{XV}$, potencializadas por meio das dinâmicas comerciais atlânticas. Como sabemos, esse comércio envolveu como eixo central das negociações a compra e venda de seres humanos, cuja marca distintiva escolhida para ressaltar a alteridade repousava sobre a cor da pele, transformando a condição negra em transnacional, infrahumana e escrava ${ }^{95}$. Além disso, o contato atlântico abriu caminho para confluências de cosmovisões e experiências distintas, objetos de estudos na historiografia com diferentes vias de interpretação. No contexto congolês, o batismo do mani Kongo Nzinga-a-Nkuwu em 1491, logo no primeiro contato com os portugueses, é o fato que mais chamou a atenção na historiografia. Tal acontecimento, inclusive, foi utilizado pelo nacionalismo português da

\footnotetext{
${ }^{95}$ Mbembe, Crítica da Razão Negra, p. 34.
} 
década de 1950 como justificativa para permanência na região durante os anos de colonização. Pouco mais tarde, a partir de 1960, novas interpretações começaram a revisar as relações entre classes superiores do Congo e o cristianismo, quer como conversão real e sincrética quer como conversão aparente e conveniente.

Podemos dividir essa produção historiográfica sobre Congo e Angola em três fases distintas. O primeiro momento se sobressaiu pela problematização da evangelização na região com foco nas distintas formas de ação missionária e têm como principais nomes Jean Cuvelier(1954), Louis Jardin (1954), François Bontinck (1970), Calogero de Pizza (1976), Teobaldo Filesi (1978), Carlo Toso (1979), Antônio Brásio (1973) e Graziano Maria da Leguzzano (1965). As obras desses autores apanham um período de 1950 a 1970 e, frequentemente, a nacionalidade e suas relações com os institutos religiosos atuantes na região influenciaram a leitura das fontes e suas obras. A problemática dessas análises reside no fato de que se recusa a pensar a ação dos missionários inserida num contexto histórico. Uma incapacidade de perceber o fenômeno dentro do contexto da contrarreforma, da afirmação da identidade europeia e da expansão aos novos mundos. Muitas das obras, ao final, são notas, comentários e traduções dos registros missionárias do século XVII e XVIII, constituindo muito mais uma memória das ordens religiosas da qual esses autores faziam parte.

Já uma segunda visão acerca dessas fontes surge ao final da segunda metade do século XX. Nela, os textos missionários eram vistos como uma noz, sendo necessário quebrar a casca de eurocentrismo desses textos para assim chegar à pureza histórica ${ }^{96}$ das sociedades africanas. O objetivo era a busca daquilo que fosse essencialmente africano. Esses trabalhos estavam situados no momento em que os movimentos de independência borbulhavam em solo africano. Deste grupo podemos nomear Georges Balandier (1965), David Birmingham (1966), Jan Vansina (1966), W. G. L. Randles (1980). Esses autores inverteram a perspectiva e o

\footnotetext{
${ }^{96}$ Essa busca da pureza histórica de uma fonte se relaciona com os princípios epistemológicos de objetividade. Quanto mais objetivamente se analisa uma fonte, mais informações sobre o real ela pode nos fornecer.
} 
acento, antes colocado sobre a ação missionária cumprida pelas ordens religiosas europeias, orienta-se agora para a análise do impacto visível da presença europeia sobre o modo de vida e as crenças desses grupos. Mas essa inversão na atenção dada ao objeto é decisivamente incrementada a partir dos trabalhos de David Birmingham e Jan Vansina.

Sem a atenção dada às ações dos grupos humanos nessas regiões, não seria possível a atuação do terceiro bloco de historiadores, que reivindicavam uma nova abordagem para as documentações produzidas por missionários. Seus representantes são Anne Hilton e John Thornton, para o estudo da região do Kongo, Joseph Miller para a região Mbundu, e mais recentemente, James Sweet, Carlos Almeida e Patrício Batiskama para ambas as regiões.

Uma vez que nossa intenção objetiva compreender como os registros missionários foram interpretados por historiadoresnão-africanos, selecionamos JanVansina, John Thornton e Carlos Almeida (autores que debatem e pensam de forma incisiva e diferente uns dos outros sobre a interpretação dessas fontes) para análise do Capítulo 3. Por ora, faremos apenas um esboço descritivo das obras de David Birmingham, Anne Hilton, James Sweet e Patrício Batsîkama para oferecer um panorama do desenvolvimento dos estudos sobre a região desde o fim da década de 1960 até 2010. A escolha desses autores seguiu uma relação com as correntes historiográficas. Se Birmingham é visto como exemplo da segunda geração, que se desvinculava de uma história das missões em Angola, Hilton e Sweet representam a terceira geração de historiógrafos atentos aos processos culturais e Batsîkama, por fim, representaria uma novíssima geração de historiógrafos que pensam sua própria história utilizando-se de uma variedade de fontes e metodologias.

\subsection{Birmingham: a desintegração política dos reinos mbundu pelo comércio escravista português.}


Em 1965 e 1966, David Birmingham publicou seus dois mais importantes trabalhos. Enquanto o primeiro,The PortugueseConquestof Angola, é um livro com explicações sucintas, o segundo,Trade andConflict in Angola, é mais abrangente e conta com dados específicos sobre o comércio de escravizados e capítulos que abordavam exclusivamente o ambiente sociopolítico dos reinos mbundu.

A tentativa de Birmingham era apresentar um cenário que dissesse muito mais sobre as colisões entre portugueses e mbundu do que narrar um episódio da "pacífica” expansão portuguesa. Suas fontes variam entre registros orais, relatos missionários e correspondências oficiais - não fazendo, a priori, nenhuma desqualificação de valor metodológico a nenhuma delas. O enfoque é na história comercial e militar e abarca um período extenso, entre 1483 e 1790. As fontes utilizadas são tradições orais encontradas em Cavazzi e nos estudos de Heveaux, analisadas em conjunto com registros e cartas da administração portuguesa encontras em sua maioria no Arquivo Histórico Ultramarino de Lisboa. Assim como Vansina, Birmingham começa a história pelas origens dos povos bakongo e mbundu, resgatando as tradições orais de cada reino antes da chegada dos portugueses na região. Esses últimos são retratados mais claramente como invasores e usurpadores da terra, aqueles que demandaram e organizaram o escravismo e desestabilizaram o reino congolês. Aliás, na narrativa de Birmingham, essa influência lusa é tão forte no Congo como em Angola.

Sua atenção primordial é o Ndongo, reino cujos senhores eram conhecidos como Ngola (daí deriva o nome do lugar que hoje conhecemos como Angola e que compreende a parte sul do Congo). Em 1520, a pedido dos missionários locais, uma embaixada foi enviada ao Ndongo no intuito de converter o Ngola. Para Birmingham, a prontidão portuguesa era mais "mercenária do que idealista" 97 e visava confirmar os boatos de minas de prata no local. A instrução do regimento que levou Manuel Pacheco e Baltazar de Castro como

\footnotetext{
${ }^{97}$ Birmingham, Trade and Conflict in Angola, p.26.
} 
embaixadores punha demasiado acento na fé Cristã como meio de estabelecer relações com o Ndongo. Assim, “uma vez a corte real estando convertida, o processo de ‘salvação’ poderia começar. Salvação foi corriqueiramente um eufemismo para escravidão"98. Daí sua interpretação para a conversão ser mais cética e tratada como uma relação comercial e de interesses.

Consequentemente, a narrativa se desenrola com foco no comércio de escravizados. Logo após o primeiro contato português com o Ndongo, esse comércio na região mbundu se desenvolveu rapidamente em decorrência das expansões do Ndongo e das batalhas portuguesas contra poderes locais. Uma expansão tão rápida que em 1532 o Mani Kongo ficou insatisfeito com a relação direta entre Portugal e Ndongo no comércio de escravos, marfim e cobre. E, apesar da oposição congolesa, a intensidade mercantil entre os dois não diminuiu. Para Birmingham, a consequência da aproximação lusa com o Ndongo resultou na verdade numa “crescente rivalidade entre os governos do Congo e Ndongo" ${ }^{99}$, conjugando numa das causas para a instabilidade política com origem na disputa de oferta aos portugueses de mão de obra escravizada, ou seja:

Os efeitos do novo comércio foram dois: o primeiro foi um enfraquecimento devido à drenagem de mão de obra, e o segundo foi o fortalecimento daqueles que controlavam o comércio de escravos recebendo riqueza e poder por meio dos bens europeus que obtinham em troca ${ }^{100}$.

Por outro lado, para Birmingham a libertação de Paulo Dias Novais em 1565, que havia permanecido prisioneiro no Ndongo desde sua chegada em 1561, marca uma nova fase na história de Angola. Ao retornar para Lisboa com pedido de ajuda do Ngola contra possíveis invasores, Paulo Dias reformularia as políticas portuguesas para África. Uma

\footnotetext{
${ }^{98}$ Idem, op. cit., p. 30.

${ }^{99}$ Birmingham, Trade and Conflict in Angola, p.33

${ }^{100}$ Idem, op. cit., p. 40.
} 
política de conquista militar onde as “duas áreas principalmente afetadas foram Moçambique e Angola” ${ }^{101}$. Nessa construção histórica fica nítido a intenção de mostrar as raízes do sistema colonial português implícitas num sistema de dominação de cinco séculos e que, no momento da pesquisa, estava se desmantelando. Afinal, as Guerras de Independência de Angola e Moçambique começaram respectivamente em 1961 e 1964.

De toda maneira, mesmo colocando acento na atividade portuguesa, ele não descarta os contextos internos de mudança nas configurações políticas mbundu e bakongo. O destaque dessas dinâmicas internas é dado nas considerações sobre as invasões Mbangalas ou Jagas ${ }^{102}$ que vinham do Leste eatingiram Congo e Angola do final do século XVI ao início do século XVII - momento em que a crescente presença europeia se fazia por meio do comércio de escravizados. As invasões, segundo ele, colocaram o poder do Ndongo diante de duas forças: portuguesa via Oeste e Mbangalas via Leste ${ }^{103}$.

Birmingham demarca as fases da presença portuguesa em períodos. Uma primeira fase mais centrada numa relação com o Congo, com uma abertura ao comércio de escravizados entre 1483, data do contato inicial, e 1565, com a libertação de Paulo Dias Noivais como cativo no Ngondo. A segunda fase vai de 1575, quando do retorno de Dias Novais e das primeiras batalhas frente ao Ndongo, até 1605 durante a chegada de Manuel Carveira Pereira nos Montes Cambambe. Esses dois períodos são marcados pelas guerras em busca das supostas minas de prata nos montes supracitados, onde a resistência do Ngola ao acesso ao local foi frequentemente interpretada como forma de proteção e consequentemente transformou a expectativa em certeza.

\footnotetext{
101 Idem, op. cit., p. 41.

102 Não existe um consenso na historiografia em relação a existência dos Jagas. Birmingham ora trata como o nome dado pelos portugueses aos Mbangalas. Veja: Birmingham, The PortugueseConquestof Angola, p. 35. Ora como povos distintos com origem nos estados Lubas. Ver: Idem, TradeandConflict in Angola, p. 65. Mas, é com Joseph Miller que a discussão ganha mais intensidade ao tratar os "Jagas" como uma imagem mitológica portuguesa sobre os Mbangalas que servia aos projetos lusitanos na conquista. Ver: Miller, Requiem for theJaga, p. 134. Thornton em seguida resgata a possibilidade dos Jagas serem um povo de oriundo dos Yakes, povos do Vale do Niari, e que de fato invadiram o Congo Ver: Thornton, A Ressurection for theJaga, p. 223-227.

${ }^{103}$ Birmingham, Trade and Conflict in Angola, p. 64-77.
} 
A terceira fase, entre 1605 e 1641, assinalada respectivamente pela decepção com a ausência de prata no Cambambe e a invasão holandesa em Luanda, foi para Birmingham o período mais desastroso. Principalmente porque a motivação primordial das guerras contra os mbundu no Ndongo se tornou a captura de escravos e não mais a busca por minas, de modo que, “comunidades inteiras desapareceram e as guerras começaram a despovoar o Ndongo a um ritmo alarmante”104. Essa penetração portuguesa também levou à conquista da capital, forçando seu governante, NgolaMbandi, a se retirar para o interior. Ora, inicialmente, com as investidas do governador Luís Mendes de Vasconcelos, parecia ser mais vantajoso a guerra ativa para fomentar o fluxo de escravizados, mas logo os seus sucessores perceberam a necessidade de negociação com fornecedores locais. É nesse contexto que a figura emblemática de NzingaMbandi, irmã do Ngola, surge como mediadora com os portugueses, inicialmente cedendo espaço aos lusitanos e depois fazendo resistência no interior. Assim, quando os holandeses invadem Luanda em 1641 eles são obrigados a lutar em duas frentes, contra Nzinga em Matamba e contra os holandeses no litoral ${ }^{105}$.

Os anos entre a invasão holandesa em 1641 e o estabelecimento da paz com o reino de Matamba em 1683 marcam a consolidação e o estabelecimento dos portugueses além do crescente escravismo - nesse momento com o reino Kasanje controlando o comércio, que até então esteve sob domínio português. Para o historiador, essa seria a quarta fase, tão devastadora quanto a terceira e onde o envio de escravizados para as Américas aumentou proporcionalmente ao domínio português sobre as chefaturas locais - com exceção de Matamba e Kasanje até 1671. Sendo “inegável que quanto mais os portugueses lucravam com as guerras mais desastrosas elas eram para os povos africanos em contato com o exército português”"106.

\footnotetext{
${ }^{104}$ Birmingham, The Portuguese Conquestof Angola, p. 34.

105 Birmingham, Trade and Conflict in Angola, p. 100-101.

${ }^{106}$ Idem, The Portuguese Conquest of Angola, p 41.
} 
Nesse ínterim, Nzinga buscou o apoio holandês para expulsão dos portugueses do Ndongo, uma aliança com êxito momentâneo, pois em 1648 um navio vindo do Brasil comandado por Salvador Correia de Sá chegava para retomar Luanda com a mesma facilidade que os holandeses tiveram para conquistar sete anos antes ${ }^{107}$. Nzinga se retirou para Matamba, no interior, distante do raio de ação dos portugueses, ação que reduziu o fluxo de escravizados e, mais uma vez, deixou perceptível para os lusitanos a necessidade de um acordo para continuar suprindo a alta demanda de mão de obra escrava. Logo os portugueses trataram de libertar Makambu, irmã de Nzinga capturada em 1654, em troca de um acordo de paz e cooperação $^{108}$.

Nesse contexto, outro aspecto da interpretação de Birmingham é que as conversões dos senhores e senhoras mbundu nunca são pensadas como uma possibilidade real. Ao tratar da afinidade de Nzinga com os capuchinhos, ele apenas cita uma "boa relação"109 com os missionários, desconsiderando das narrativas de Cavazzi a conversão ao cristianismo.

Por fim, a quarta fase da presença europeia analisada pelo historiador abrange os anos entre 1683 a 1790. A primeira data é escolhida como marco pelo estabelecimento de paz com $M a t a m b a^{110}$. Já a segunda é marcada pela retomada do controle português do comércio escravista. Para Birmingham, esse período se caracteriza pelo desenvolvimento de um comércio interno de escravizados, alcançando regiões muito mais distantes para o interior. Outro aspecto é que se no século XVII, os maiores rivais dos portugueses nesse comércio eram os holandeses; já no século XVIII os franceses e os ingleses tornaram-se os maiores concorrentes na costa de Loango, região ao norte do rio Congo ${ }^{111}$. Nesse período, o transporte de centro-africanos para a América chegou ao ponto mais alto, nos cálculos de Birmingham

\footnotetext{
${ }^{107}$ Idem, op. cit., p. 44.

${ }^{108}$ Birmingham, Trade and Conflict in Angola, p. 115.

${ }^{109}$ Idem, op. cit., p. 122-123.

${ }^{110}$ Idem, op. cit., p. 133.

${ }^{111}$ Idem, The Portuguese Conquest of Angola, p.51-52.
} 
uma média de 12 mil por ano ${ }^{112}$. Daí que um comércio perceptivelmente lucrativo atraia forte concorrência amenizada apenas em 1790, de modo que os portugueses continuaram sendo “os perpetuadores cada vez mais criticados do tráfico de seres humanos”113.

Tanto The PortugueseConquestof Angola como Trade andConflict in Angola tencionam revelar as bases do colonialismo português que foram, durante três séculos, as guerras crescentes frente aos poderes mbundu e bakongo e o fomento do comércio de escravizados que em medos do século XVIII passou a ser autossuficiente. Importante destacar o papel central que o comércio escravista tem na narrativa de Birmingham, sendo as investidas portuguesas interpretadas como uma consequência do esforço para fomentar o comércio. O motor das ditas “conquistas” é a articulação por meio dos missionários e a compra e venda de seres humanos. Birmingham aborda o cristianismo na região de forma mais cética, ou seja, entende que o catolicismo foi apropriado e difundido apenas pelo fator de influência comercial e desconsidera a crença real dos princípios religiosos entre os partícipes da religião. Esse caráter se alinha com a história marxista característica dos anos 1960 e 1970, onde as análises estão voltadas para a economia e estrutura social. Diferentemente, como veremos, da historiografia dos anos 1980, que ressaltará os aspectos culturais e comportamentais de modo que a cosmologia, religião e outros aspectos ganham mais espaço nas obras históricas.

\subsection{Anne Hilton: uma análise das instituições políticas através da cosmologia bakongo.}

A obra de Hilton não é extensa, mas adquiriu uma relevância nos estudos sobre o Congo depois de publicar sua tese The Kingdomof Kongo, em 1985. Uma de suas preocupações ao longo do livro é entender como o universo congolês meditou sobre o

\footnotetext{
${ }^{112}$ Idem, Trade and Conflict in Angola, p. 155.

${ }^{113}$ Idem, The Portuguese Conquest of Angola, p. 60.
} 
impacto do cristianismo. Suas bases de análise foram os registros missionários e, diferentemente de Thornton, uma extensa literatura de investigação antropológica moderna que versa sobre a cosmologia da região. Para ela, a cosmovisão congolesa reinterpretou imagens e rituais cristãos sem perder sua lógica. A experiência do convívio de ideias e mitos europeus e africanos teria resultado num processo "sincrético" imperceptível e independente da vontade de missionários ou de populações locais.

Hilton evidencia esse processo através de um problema central nos sentidos das traduções feitas por missionários, como por exemplo, com o conceito de nzambimpungutraduzido para Deus. Nzambi seria uma “força superior” em um contexto particular, enquanto mpungu significaria “supremo" resultando na tradução "força superior suprema”. De fato, os sentidos entre Deus e nzambimpungu seriam próximos, mas em contextos diferentes Hilton mostra, em mais de uma fonte, que o conceito bakongo poderia significar no contexto familiar, por exemplo, a linhagem matrilinear. Ou ainda, assumir significados de honraria ao ponto de no começo do século XVII mani Loango ser chamado de nzambimpungu, provavelmente por ser a maior autoridade responsável pela mediação com a dimensão do nkadimpemba. Assim, os sentidos para o termo nzambimpungu seriam relativos a contextos particulares. Os congoleses não estariam interessados em definir um termo de uso geral e, por outro lado, os europeus interpretavam essa atitude como desconhecimento total sobre Deus ${ }^{114}$.

Assim também aconteceu com o conceito cristão de paraíso e inferno, dotado como uma adição às crenças locais e/ou comumente rejeitado. Na ocasião, os missionários utilizavam o termo mazulu, céu, para indicarem o paraíso e o termo bulungi para designar o inferno. Mas isso causava confusão, primeiro porque era difícil conciliar o céu com o mundo subterrâneo dos mortos, depois que o significado de bulungi era usado para designar as

\footnotetext{
${ }^{114}$ Hilton, The Kingdom of Kongo, p. 91-92
} 
cabanas à beira do mar onde os malfeitores repousavam após a morte. A isso, somava-se que ambos os conceitos (mazulu e bulungi) estavam englobados na kalunga, que poderia indicar o mar, grande massa de água e barreira entre o mundo dos vivos e dos mortos. Logo, não era de se espantar, segundo Hilton, que os conceitos de paraíso e inferno fossem rejeitados. Os relatos dos capuchinhos na metade do século XVII mais de uma vez mostravam que as populações classificavam como mentira a impossibilidade de transitar entre o paraíso/mazulu e o inferno/bulungi ${ }^{115}$.

Ao mesmo tempo, os missionários adquiriram um papel importante nos cultos fúnebres. Para Hilton, isso foi facilitado pela proximidade nas formas de enterro. Enquanto europeus enterravam os mortos nas igrejas ou ao lado delas, os congoleses enterravam os mortos em cabanas próximas aos povoados. No século XVII todas as igrejas de Mbanza Kongo possuíam tumbas e as igrejas eram conhecidas como nzo a nkisi(casa do sagrado), onde os sacerdotes cristãos eram utilizados exclusivamente nos funerais da realeza. Hilton destaca, por exemplo, o funeral de Álvaro III em 1622, quando oficiais carregaram as almofadas usadas pelo rei na igreja, seguidos por músicos, por membros da Irmandade da Santa Mercê e pelo clérigo que ia à frente do corpo carregado por seis nobres. Na ocasião Álvaro foi enterrado conforme os rituais romanos na igreja de Santo Antônio ${ }^{116}$.

Outro aspecto dessas relações entre cristianismo e poder no Congo foi ensaiado por Hilton. Muitas vezes o mani Kongo utilizava os serviços da igreja para enfatizar a legitimidade do seu governo nos termos dos seus predecessores e reafirmar a unidade entre os demais governantes locais. No dia de São Tiago, por exemplo, ele presidia uma celebração pela miraculosa intervenção do santo na batalha que assegurou o trono de Afonso e sua linhagem real. Essa lógica era reaplicada nas cidades vizinhas submetidas aMbaza Kongo. De acordo com os registros encontrados por Hilton, na metade do século XVII as demais cidades

\footnotetext{
${ }^{115}$ Idem, op. cit., p. 94.

${ }^{116}$ Hilton, The Kingdom of Kongo, p. 95.
} 
possuíam igrejas conforme o tamanho da população. Em MbanzaNsoyo chegavam a mais de oito, assim também como em MbanzaNsundi. Os governantes utilizavam as igrejas, conforme a chegada dos priores, para exaltar suas posições de poder e controle sobre a dimensão de nkadimpenba (mundo dos espíritos), onde os rituais tinham como foco eles mesmos ${ }^{117}$.

Assim, enquanto o cristianismo foi interpretado como um culto da dimensão de nkadimpemba e os túmulos juntamente aos cultos fúnebres serviram para legitimar e definir as elites bakongo com uma hierarquia dentro dela, o ajuste entre o cristianismo e os conceitos cosmológicos locais permaneceu inexato. Para Hilton, portanto, o mundo congo absorvia os elementos cristãos reinterpretando suas figuras sem perder sua coerência, num palco de dinâmicas históricas onde cosmologia e política são indissociáveis.

Por fim, em relação às fontes missionárias, ela estabeleceu um modelo de leitura que considera os caminhos de cada missionário em seus espaços de experiência com a realidade africana. Sua proposta admite que as cartas redigidas durante o primeiro ano de ação revelam uma expectativa muito grande quanto à conversão das elites no Congo; desembocando numa segundo ocasião, quando o missionário se confronta com as práticas religiosas africanas e expressa desânimo e vontade de retornar; e por fim, num terceiro momento - onde apenas capuchinhos são o exemplo ${ }^{118}$ - esses missionários desenvolvem uma adequação nas estratégias de conversão que não podem ser percebidas como assimilação cultural.

Essa consideração dos aspectos religiosos na política congolesa entre os séculos XVII e XVIII foi uma inovação para a historiografia dos fins de 1970 e início dos anos 1980. Antes disso as dimensões políticas e econômicas eram hegemônicas nos estudos históricos, como vimos no caso de David Birmingham. Contemporâneo de Hilton na produção, Thornton também considerou os aspectos religiosos nos processos congoleses no século XVII. Para ele, no entanto, e como veremos no Capítulo 3, o cristianismo assumiu um papel estruturante na

\footnotetext{
${ }^{117}$ Idem, op. cit., p. 101.

${ }^{118}$ Idem, European Sources for the Study of Religious Change in Sixteenth and Seventeenth Century Kongo, p.293.
} 
sociedade congolesa de modo a criar um universo mental religioso conciso que perdurou para além do Atlântico. Contudo, recentemente, nos anos 2000, James Sweet e outros autores se aproximaram das leituras de Hilton para interpretar o mundo atlântico afro-português.

\subsection{James Sweet e a coexistência de múltiplas identidades religiosas.}

James Sweet é norte-americano e seus estudos estão concentrados mais na diáspora africana provocada pelo sistema escravista e menos nas dinâmicas internas no Congo e Angola, mas apesar disso ambas as regiões são centrais no seu trabalho. Seu livro Recriar África: cultura, parentesco e religião no mundo afro-português 1441-1770 é dividido em três partes: a primeira trata da demografia, das relações familiares e dos recursos de sobrevivência física dos africanos nas Américas; depois, aborda as respostas religiosas de sobrevivência; e por fim, elabora uma relação entre africanos e a Igreja Católica.

Ao considerar a demografia,Sweet faz uma análise qualitativa das relações de parentesco no mundo Atlântico. Quando aborda casamento, ele insiste na ideia de que essa instituição oficializada não era considerada algo importante para as populações escravizadas, um desinteresse do qual os missionários já se queixavam em África uma vez que as relações ali se davam de uma forma diferente ${ }^{119}$. Por outro lado, os próprios senhores não incentivavam o casamento por ser inconveniente com as práticas econômicas. Logo, a formação de laços familiares em terras brasileiras era um processo fluido que incluía inúmeras variedades de $\operatorname{acordos}^{120}$. Ainda sobre as relações pessoais reconstruídas do outro lado do Atlântico, ele chama a atenção para as relações afetivas entre homens. Atribui a isso tanto as diferenças numéricas entre escravos do sexo masculino e feminino (no caso havia um número muito maior de homens), quanto às experiências prévias em África. Era o caso, por exemplo,

\footnotetext{
${ }^{119}$ Sweet, Recriar África, p. 56

${ }^{120}$ Idem, op. cit., p. 70.
} 
dos sacerdotes quimbandas, líderes espirituais que se travestiam e eram vistos e tratados como seres com ambos os sexos ${ }^{121}$.

O livro também trata o ambiente de tensões corriqueiras do sistema escravista e as relações entre senhores e escravizados, alertando sobre o impacto das violências nas vidas das crianças e a baixa expectativa de vida. Simultaneamente, ele desconstrói as ideias idílicas de Gilberto Freyre, evidenciando como as relações sexuais entre senhores e escravizadas era abusiva. Nesse contexto o equilíbrio, ou melhor, a manutenção das tensões perpassava pelas estratégias de sobrevivência dos escravos baseada na espiritualidade e na fé, e é aqui que o trabalho de Sweet se destaca ${ }^{122}$.

Porém, antes de considerar os aspectos religiosos ele dirige uma crítica à forma como alguns estudiosos entenderam a relação de africanos com suas crenças. Partiam do pressuposto equivocado de que "uma vez que a maioria dos africanos não fazia parte de uma das grandes religiões monoteístas, os escravos eram uma “tábua rasa” religiosa, rapidamente convertível ao Cristianismo”123. No seu entendimento, a maioria dos africanos que chegavam às Américas perpetuava as práticas e as visões cosmológicas que apreendiam em África. Por isso Sweet acredita que ao comparar as crenças e práticas rituais dos "centro-africanos em África com as crenças e práticas dos seus irmãos no continente americano, será possível demonstrar que certas crenças não foram destruídas pela influência do cristianismo ocidental” ${ }^{124}$.

É fato que existia uma variação muito grande das práticas religiosas, a depender de grupos e regiões. Porém, para ele, em termos gerais, uma das características mais particulares das crenças centro-africanas era a divisão entre o mundo dos vivos e o mundo dos mortos, separados por uma grande massa de água. Nessa fluidez entre esses dois mundos, os mortos

\footnotetext{
${ }^{121}$ Idem, op. cit., p. 74.

${ }^{122}$ Sweet, Recriar África, p. 81-108.

${ }^{123}$ Idem, op. cit., p. 125-126.

${ }^{124}$ Idem, op. cit., p. 127.
} 
nunca chegavam a abandonar completamente o mundo dos vivos. Eles eram consultados nas decisões familiares, regulavam padrões morais e assistiam às disputas comunitárias. "Dessa forma, os vivos e os mortos formavam uma só comunidade, sendo que as obrigações sociais e morais eram recíprocas” 125 .

Outro alerta de Sweet diz respeito às dificuldades que as visões ocidentais imprimiram acerca das culturas africanas. O historiador argumenta que, mesmo nos dias de hoje, a historiografia da África e da diáspora africana sofrem - por parte de alguns acadêmicos cristãos “devotos” - do paradigma dominante judaico cristão. E assim, considera três equívocos de interpretação que a cosmologia centro-africana tem sofrido. Primeiramente, de acreditar que a ideia de um Deus único, onipotente e imutável também se aplica à cosmologia bakongo. Essa relação foi feita principalmente através da correspondência de nzambimpungu, o criador de todas as coisas, e para Sweet essa relação não era de todo cabível porque o criador não interferia diretamente no cotidiano das pessoas, sendo esse um papel dos espíritos e das divindades. O segundo equívoco consiste na ideia de que esse Deus é uma entidade misteriosa e incognoscível, que habita num paraíso, e a ideia de céu era algo completamente distante da crença centro africana. Por fim, o terceiro equívoco, era partir do pressuposto de que a religião servia para manter um contato direto com esse Deus, quando na verdade servia mais para a manutenção de coisas práticas da vida ${ }^{126}$. E, embora as cosmologias europeias e africanas sejam, em grande medida, incompatíveis, Sweet mostra como o intercâmbio religioso pouco tem a ver com a substituição de um sistema de crenças por outro, como fez parecer Thornton. Em vez disso, para ele, o intercâmbio religioso entre africanos e europeus dependeu de uma série de revelações partilhadas, que tiveram eco nas tradições espirituais de ambos.

\footnotetext{
${ }^{125}$ Idem, op. cit., p. 128.

${ }^{126}$ Sweet, Recriar África,p 131-133.
} 
Aqui surge a maior crítica de Sweet a Thornton, com um resgate de Anne Hilton, que nunca chegou a entrar num embate direto com o último. Ele reconhece a importância de Thronton para a compreensão da formação do Cristianismo africano:

As explicações de Thornton sobre a forma como as revelações africanas foram integradas no pensamento católico são convincentes até um certo ponto. Quando os padres católicos estavam dispostos a fazer concessões espirituais e a admitir a validade de certas revelações africanas, alguns Congoleses foram integrados no Cristianismo. De fato, uma das contribuições mais importantes do trabalho de Thornton é a ideia de uma versão profundamente africanizada de Cristianismo, surgira no Congo durante o século XVI. Porém os padres católicos apenas aprovavam uma pequena parte das revelações congolesas, considerando as restantes o resultado da influência do Diabo. Enquanto que a IgrejaCatólica considerava as revelações como manifestações, extremamente raras, da vontade de Deus, os Congoleses dependiam da continuidade das revelações para a sua sobrevivência.

Ao privilegiar a revelação sobre a cosmologia em sentido lato, Thornton minimiza a verdadeira essência do pensamento religioso centro-africano. A cosmologia da África Central foi construída a partir da necessidade de uma constante revelação, enquanto que o Cristianismo gradualmente se tornou uma religião baseada na comunhão com o Deus único e "verdadeiro". [...] Quando os santos católicos se revelavam, a validade da revelação tinha de ser confirmada pelo clero, um obstáculo irritante que não tinha qualquer precedente no pensamento africano. Por seu lado, a revelação centroafricana era vulgar, contínua e incluí uma vasta gama de divindades locais e espíritos ancestrais, cuja função era intervir, a partir do mundo exterior, em benefício dos habitantes do mundo temporal ${ }^{127}$.

Sweet admite que uma parte da elite congolesa se tornou conhecedora dos mandamentos e sacramentos da Igreja e que outros eram cristãos apenas de nome. No mínimo, muitos congoleses se encontravam familiarizados com as "linhas gerais da Fé”, adicionando os elementos do catolicismo ao seu conjunto de crenças espirituais. Porém, afirmar que os congoleses eram cristãos é proporcional a retirar-lhes a capacidade de manter seus fundamentos e sua espiritualidade. "O catolicismo não era suficiente para satisfazer as

\footnotetext{
${ }^{127}$ Sweet, Recriar África, pp. 134-135.
} 
necessidades concretas da maioria dos Congoleses, mesmo durante o século XVIII - dois séculos depois de este ter sido introduzido como religião do Estado.”128.

Por conseguinte, para Sweet, embora Thornton apresente uma análise concisa das complexidades e contradições do "Cristianismo Africano", continua rotulando os congoleses como fundamentalmente cristãos. E por mais que ele não ponha em causa o argumento de Thornton sobre a adoção do cristianismo como uma peça fundamental da identidade individual e coletiva congolesa, ele questiona até que ponto a identidade cristã se sobrepôs a outras identidades religiosas. Logo, o problema se torna de outra ordem, qual seja, "não possuirmos um esquema conceptual para descrever o sistema de crenças congolês que absorveu o cristianismo naturalizado" ${ }^{29}$. Como veremos adiante, tanto Mbembe quanto Almeida conseguiram dar uma base de sustentação teórica para esse paradoxo utilizandosedas teorias que enxergam indivíduo e sociedade como indissociáveis numa análise histórica ou sociológica.

Consequentemente, Sweet revisa o conceito de crioulização ${ }^{130}$. De fato, as conclusões sobre família, parentesco e o papel da religião sugerem que os valores culturais e religiosos dos povos africanos foram transferidos parao continente americano. Mas, para ele, é primordial entender a complexidade das experiências religiosas dos africanos no contexto da diáspora, que não pode ser explicada totalmente pelo conceito de crioulização ou pela abordagem das sobrevivências, uma vez que os novos estudos sobre o tráfico revelam que os africanos nem sempre chegavam às Américas em “multidões” heterogêneas. Pelo contrário, muitos chegavam inseridos em agrupamentos coesos, com muita coisa em comum. O desafio

\footnotetext{
${ }^{128}$ Idem, op. cit., p. 137.

${ }^{129}$ Sweet, Recriar África, p. 138.

130 “Crioulização” foi o conceito utilizado por Thornton, aproveitado das noções de Ira Berlin, para explicar o enlace cultural nas populações negra nas Américas e Caribe.
} 
que se coloca aos investigadores é o de identificar estas sobrevivências nos seus vários contextos históricos, do continente africano às Américas ${ }^{131}$.

\subsection{PatrícioBatsîkama, o resgate das instituições políticas pré-coloniais.}

Recentemente, contudo, se percebe um resgate da história das instituições políticas congolesas desde suas origens. Um resgate diferente daquele promovido pela historiografia africana marxista partidária e nativista. O nome mais emblemático nesse caso é o de Patrício Batsîkama que, em nome do pluralismo e das múltiplas ancestralidades, relê a história précolonial congolesa com um aparato teórico-metodológico diverso.

As obras de Batsîkama estão apoiadas numa paleta de fontes que são textuais, orais e arqueológicas. Historiadorangolano de origem congolesa, suas influências são múltiplas, com uma clara referência ao seu avô, Raphael Batsîkama, historiador congolês radicado em Angola. As bases teóricas utilizadas nas análises são a linguística comparada, a paremiologia $^{132}$ e a crítica histórica ${ }^{133}$. Sua preocupação primordial é repensar as “Origens” do reino do Congo a partir principalmente da tradição oral ${ }^{134}$. Para tanto, ele utilizou os registros orais compilados por Jean Cuvelier (missionário belga no Congo do início do século $\mathrm{XX)}$, juntamente com um estudo de Jan Vansina, Van Wingeseus registros de campo realizados em 2003, quandorecolheualgunszimvila ${ }^{135}$ que não constavam nas compilações de Cuvelier.

\footnotetext{
${ }^{131}$ Sweet, op. cit., p. 142.

${ }^{132}$ Estudoscomparado dos provérbios.

${ }^{133}$ Batsîkama, Democracia no Reino do Kongo, p. 14.

${ }^{134} \mathrm{~A}$ obra de Batsîkama, apesar de recente, é bastante extensa. Três livros que tratam especificamente das origens do Congo cuja primeira obra é As Origens do Reino do Kôngo, seguida de As Origens Meridionais do Reino do Kôngo e As Origens do Reino do Kôngo Consoante a Bibliografia e a Tradição Oral. Além dessa trilogia, o autor também lançou em 2013 Lûmbu: a democracia no antigo Kôngo reconsiderando as interpretações sobre as instituições congolesas.

${ }^{135}$ Provérbios que narram as linhagens familiares no congo.
} 
Na sua visão, a tradição oral é pouco utilizada por não convencer boa parte dos “cientistas mais céticos”, e isso se dá porque “a ciência se autodefine como conhecimento exato das coisas determinadas”" ${ }^{36}$. Ora, sendo a tradição oral um conhecimento pouco definido, seria de imediato um conhecimento não exato. Por conseguinte, essa questão desencadeia outras duas problemáticas recorrentes nos estudos da história de África précolonial. De um lado, uma questão levantada pela geração de Ki-Zerbo:como conservar apenas as fontes válidas? Ou seja, uma pergunta que esconde por trás uma falta de metodologia própria e uma arbitrariedade do investigador. Por outro, o fato de grande parte das compilações dessas tradições serem fruto do trabalho de não-congoleses ${ }^{137}$.

Para a primeira questão,Batsîkama propõe assumira teoria e as possibilidades da tradição oral nos termos da metodologia de Vansina já que, para ele, essa teoria demonstrou que os relatos orais obedecem a uma estrutura e logo não há a necessidade de intromissão do investigador nas recolhas ${ }^{138}$. À segunda problemática ele propõe um diálogo com os trabalhos produzidos por não-congoleses, considerando-os relevantes “em termos de quantidade e

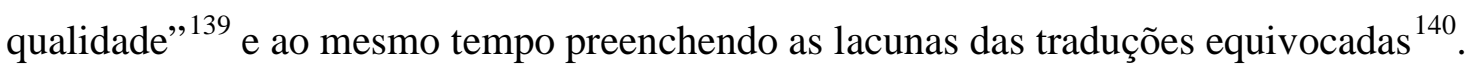

Com efeito, seu estudo possibilitou refletir sobre como foram interpretadas as instituições políticas congolesas pré-coloniais, resultando no livro Lûmbu: a democracia no Antigo Kôngo. Aqui,Batsîkama se preocupa primordialmente em esmiuçar as raízes históricas do $L u ̂ m b u$, para ele a instituição máxima do antigo Congo. O Lûmbu definia as tipificações do poder, instituía órgãos da sistematização desse poder e simbolizava a coesão de uma vasta população repartida em várias terras distantes umas das outras ${ }^{141}$.

\footnotetext{
${ }^{136}$ Batsîkama, As Origens do Reino do Kôngo, p.26.

${ }^{137}$ Idem, op. cit., pp. 26-36.

${ }^{138}$ Batsîkama, As Origens do Reino do Kôngo, p. 32.

${ }^{139}$ Idem, op. cit., p. 33.

140 É caso, por exemplo, da tradução do termo ndoki como bruxo. De acordo com as demonstrações feitas por Batsîkama“"ndoki só pode significar o 'poder que possui o bruxo', mas não é o próprio bruxo. É índice de quantas outras realidades e instituições do Kôngo (e não só) que terão sido interpretadas aproximadamente sem corresponder fielmente ao pensamento primordial do Kôngo”. Ver: Idem, op. cit., p. 35.

${ }^{141}$ Batsîkama, Lûmbu: a democracia no antigo Kôngo, p. 37.
} 
Essa instituição era complexa e dividida em vários órgãos, mas tinha sobretudo a função de eleger o próximo líder. O primeiro, denominado Mpôlo’aLêmba, tinha responsabilidade de zelar pelas campanhas dos candidatos ao cargo, o que objetivava tornar o processo pacífico. O segundo, o Mfûmu'aLêmbaou Kimfûmu, tratava da educação dos candidatos, onde aprendiam os tipos de governo, o significado das insígnias de poder, o kimpôvi, espécie de técnica retórica utilizada na aplicabilidade das leis e o kikûlu, uma compilação da história geral do país, já que os candidatos conheciam apenas as histórias das suas respectivas regiões. O terceiro levava o nome dessa instituição, o Lûmbu, onde os candidatos deveriam provar a capacidade no conhecimento das leis e, caso um ou mais candidatos fossem reprovados, poderiam entrar com “recurso", auxiliado pelo Na Mpemba. Ao final, legitimava-se eleito, cuja preparação para investidura se dava no Mbôngi, quando lhe eram delegados os poderes executivos e reunia-se o Lûmbu para a edição das leis que o eleito iria proclamar ${ }^{142}$.

O livro carrega em si também uma defesa política do Lûmbu. Demonstradas as raízes históricas da instituição, Batsîkama pretende defender por meio dela a candidatura de Mbânz’aKôngo como Patrimônio da Humanidade. Além disso, propõe também a possibilidade da inclusão das atuais autoridades do Lûmbu no Estado angolano, associando-os aos ministérios da Justiça, Família e Promoção ${ }^{143}$.Por um lado, a tentativa de Batsîkama pode ser interpretada como o resgate do tradicional para fortalecimento da identidade nacional. Por outro, é notório perceber que a proposta carrega a possibilidade de múltiplas ancestralidades, reivindicando uma partilha entre Congo e Angola de um patrimônio comum e incluindo num modelo de Estado construído sobre as bases europeias.

Finalmente, tendo demonstrado através de alguns exemplos os caminhos trilhados pela historiografia referente ao Congo e Angola, pretendemos analisar a fundo alguns autores

\footnotetext{
${ }^{142}$ Batsîkama, Lûmbu: a democracia no antigo Kôngo, pp. 37-44.

${ }^{143}$ Idem, op. cit., p. 59.
} 
que pensaram em formas e possibilidades metodológicas para o uso dos registros missionários na região. As questões principais que giram ao redor desse material são: “afinal, como trabalhar com registros de missionários que carregam o etnocentrismo latente? São confiáveis? Devemos utilizar unicamente a história oral?”. Questões por vezes levantadas sem a reflexão das respectivas posições dos pesquisadores em relação aos seus próprios “objetos”. Ou seja, sendo não-congoleses ou não-angolanos, tentam pensar como congoleses e se julgam capazes de avaliar o quão eurocêntricas podem ou não ser as fontes, revogando dessa forma as vozes de uma autoridade máxima sobre a história desses locais.

\section{JAN VANSINA, JOHN THORNTON E CARLOS ALMEIDA: OS SUCESSIVOS DEBATES TEÓRICO-METODOLÓGICOS.}

Vimos no primeiro capítulo que as representações, as identidades, as histórias e as ideias sobre africanos foram marcadas por alguns tipos de discursos, como tem destacado estudos recentes $^{144}$. Para AchilleMbembe existem dois discursos que pontuam profundamente as formas como o self africano foi inscrito e se inscreveu no mundo. De um lado o discurso nativista, com a proposta que enfatiza a “condição nativa” como promessa de uma identidade africana baseada no pertencimento à raça negra. Por outro, um discurso instrumentalista que utiliza categorias marxistas e nacionalistas "no qual a manipulação da retórica da autonomia, da resistência e da emancipação serve como o único critério para determinar a legitimidade do discurso “africano" autêntico" ${ }^{145}$. Valentim Mudimbe, por sua vez, demonstrou como as diferentes formas discursivas sobre África - quer na “arte africana” ou na invenção do

\footnotetext{
${ }^{144}$ Mbembe, As Formas Africanas de Auto Inscrição; Mudimbe, A Ideia de África.

${ }^{145}$ Idem, op. cit, p. 174.
} 
“Africanismo" como disciplina acadêmica - ilustram a eficácia dos mecanismos de classificação e padronização da realidade ${ }^{146}$. E, ao analisar as bases epistemológicas do relativismo cultural próprio das teses antropológicas, colocou em questão tanto a possibilidade de fusão do Eu com o Outro, que tinha por objetivo um real conhecimento da realidade, quanto a transparência do objeto dessa ciência, ou seja, o ser humano “como dado óbvio justificado pela história e a dinâmica do espaço cultural”147.

Já no segundo capítulo traçamos um panorama das teses históricas dedicadas ao estudo das relações entre mbundus, bakongos e europeus no decorrer da modernidade atlântica entre os séculos XVII e XVIII, dedicando atenção àquelas que problematizaram o aspecto das relações entre concepções cosmológicas europeias e bakonga, e que historicizamum processo da formação das diferenças. Além disso, ao descrever as obras de alguns historiadores, percebemos o desenvolvimento dos estudos que desviaram o foco das instituições políticas e econômicas para os recursos cosmológicos como partes complementares e indissociáveis dessas mesmas instituições.

Agora, nossa pretensão é identificar como os diferentes discursos sobre África influenciaram uma larga produção historiográfica - produzida por não-africanos - e que versa sobre Congo e Angola dos séculos XVII e XVIII, influência sentida principalmente através dos discursos nativistas ligados às questões sobre "natureza africana” e de anulação do Eu ante ao Outro, cujo relativismo cultural é sua base de sustentação. Concomitantemente, perceberemos como as influências desses discursos não se restringem às interpretações dos processos históricos dessas sociedades, estando intimamente ligados às propostas teóricometodológicas de análise das fontes missionárias.

Por isso, elencamos para essa análise três autores. De um lado, Jan Vansina e John Thornton, tidos como referências no estudo sobre Congo e Angola nos séculos XVII e XVIII,

\footnotetext{
${ }^{146}$ Mudimbe, A Invenção de África, p. 25.

${ }^{147}$ Idem, A Ideia de África, p.77.
} 
propondo perspectivas de análise das fontes próximas ao relativismo cultural e ao estruturalismo. De outro, Carlos Almeida, que relaciona os estudos africanos às teorias críticas e ao estruturalismo, com uma análise histórica da região no mesmo período.

\subsection{JanVansina: entre história e antropologia.}

A trajetória biográfica de Vansina é amplamente conhecida graças a um livro de memórias publicado na década de $1990^{148}$. Belga nascido na cidade de Antuérpia em 1929, Vansina foi o sétimo de uma família católica com doze filhos. Sua casa estava envolvida no meio cultural, sua mãe foi pintora e seu pai escritor e historiador de arte. Durante os anos da Guerra, sua vida e educação ficaram conturbadas. Sua mãe teve que mandá-lo para uma escola beneditina onde, a seu contragosto, estudou com as elites flamengas que recorrentemente o lembravam da sua origem "plebeia”. No agravar das batalhas, a escola se tornou itinerária, com aulas ministradas em castelos ou nos fundos de fábricas. E no final, com a invasão da Normandia e a suspensão do período letivo, o jovem Vansina, que acabava de completar quinze anos, se deparou com uma cena inquietante: outro jovem, com talvez três anos a mais, caído ao chão com a vida ceifada pelas mazelas da guerra. Desde aquele momento até então ele passou a “odiar a intolerância e qualquer ortodoxia com uma paixão imortal" 149 .

Com a derrota nazista e o estabelecimento da paz na Europa, era necessário retomar os estudos. Contudo, não seria fácil resistir mais um ano na escola beneditina - e na companhia dos colegas - que denominou de "sepulcro esnobe". Sua mãe o incentivou a prestar o exame que substituiria os anos de ensino médio e, se aprovado, estaria livre para ingressar na universidade. Vansina foi um dos poucos bem sucedidos e tinha na época o

\footnotetext{
${ }^{148}$ Vansina, Living With Africa.

${ }^{149}$ Vansina, Living With Africa, p. 5.
} 
desafio de aos dezesseis anos escolher uma carreira a seguir. Ele queria ser escritor e seu pai, no entanto, o matriculou na escola de medicina da Universidade Católica de Leuven. A crise sobre a opção profissional seguida de um baixo desempenho persistiu até a família aceitar a transferência para o direito - cursado conjunto e secretamente com as matérias de história. Assim, após dois anos, Vansina adquiriu bacharelado em ambos os cursos.

Na Universidade de Leuven o curso de história foi estruturado por Ernest Cauchie, pupilo de Ernest Bernheim ${ }^{150}$. Nesse ambiente Vansina desenvolveu seu mestrado sobre cantos líricos medievais e tradição oral na Idade Média. Como ele mesmo confessa, era um historiador com o dever perante a "verdade”, que via a história como a correta reconstrução do passado. E, mesmo sua geração se sentindo positivista, não abria mão de Apologiepourl'histoire de Marc Bloch, ao mesmo tempo em que olhava desconfiadamente para o curso ministrado por Fernand Braudel em 1949, na Universidade de Leuven, sobre os tempos de longa duração combativa à história dos eventos ${ }^{151}$. Esse misto de autocondenação positivista e ansiedade por algo novo na metodologia da história fora sintomático para toda geração de historiadores do pós-guerra, como também foram as disputas por espaço acadêmico entre a história e as recém-consolidadas ciências sociais. Vansina não escapou de ambas as experiências. Se por um lado ele propôs inovar metodologicamente com a utilização de tradições orais na história, por outro foi atraído para os estudos antropológicos através da oportunidade de emprego no Museu Real do Congo Belga na cidade de Tervuren.

Ali teve contato com as produções do então diretor do museu, o antropólogo FransOlbrechts, de quem precisou ler toda bibliografia para aprovação no cargo de pesquisador. Os trabalhos de Leo Frobenius e E. E. Evans Pritchard também fizeram parte dessas primeiras leituras no campo antropológico. Após três anos de estudo na área, Olbrechts lhe indicou duas grandes oportunidades: a primeira era continuar os estudos na

\footnotetext{
${ }^{150}$ Berheim foi um dos grandes difusores do método histórico alemão no ambiente francês, sobretudo aquele com bases nas ideias de Johann Gustav Droysen.

${ }^{151}$ Vansina, Living With Africa, p. 6-7.
} 
UniversityCollege London, e a segunda, desenvolver um trabalho de campo com os Kuba no Congo após esse período na Inglaterra. A primeira oferta proporcionou uma relação com toda a sorte de estudiosos da escola estrutural-funcionalista inglesa, enquanto a segunda forneceu a oportunidade de desenvolver o trabalho que seria o marco na sua carreira, no caso, De laTraditionOrale.

Em Londres, teve aulas com DaryllForde, Mary Douglas, Michael Smith e PhyllisKaberry, mas as relações com Douglas e Forde foram especiais devido a proximidade dos campos de estudo. No entanto, Vansina lembra que nas correções de seus artigos, Mary Douglas sempre acusava, em um ou outro trecho, a palavra "História!” como algo negativo que não deveria sobrepor a estrutura. Todos os britânicos da linha funcional estruturalista eram assim, exceto DaryllForde. Por isso, foi o que mais influenciou suas ideias, justamente pelo estilo pouco pareado ao funcionalismo. Em entrevista mais recente,Vansina confessa que, já naquela época, a teoria inglesa lhe causa admiração e desconfiança, admiração por ser algo novo e desconfiança porque o funcional estruturalismo fornecia uma:

via sincrônica, mas fazendo isso - por meio da etnografia presente apagava realmente todos os problemas da mudança, e por isso se a sociedade era perfeitamente balanceada, então como nunca poderia mudar, exceto se fosse pressionada por fora? ${ }^{152}$

Toda essa primeira fase de relação com a antropologia e os métodos de crítica histórica é bastante perceptível em De laTradicionOrale, de 1961. As perguntas que norteiam o trabalho revelam o momento pelo qual ainda passava o pesquisador: “A priori a tradição oral como um todo pode ser validada como fonte histórica? Se não, o que dela pode ser significativo para a realidade?” ${ }^{153}$.Era preciso inserir as tradições orais - fontes exclusivas da antropologia - no método histórico voltado para o acesso do realmente vivido, e fazendo isso,

\footnotetext{
${ }^{152}$ Whitehead \&Vansina, An Interview with Jan Vansina, p. 306

${ }^{153}$ Vansina, Oral Tradition, p. 1.
} 
Vansina ansiava colocar as populações sem registros escritos dentro da historicidade negada. Para realizar esse empreendimento, era necessário conciliar história e antropologia, disciplinas que naquele momento tentavam entrar em acordo sobre a relação entre estrutura e conjuntura. Consequentemente, o início do livro revela as lacunas deixadas por uma e outra no entendimento das tradições orais e da história da África.

As primeiras pesquisas sobre tradição oral feita por historiadores no final do século XIX e no começo do século XX estavam vinculadas, sobretudo, aos estudos de antiguidade clássica e história medieval. Vansina relembra dos nomes de Dumézil, E.Berheim, A. Feder e W. Bauer cada um com suas particularidades, mas tendo em comum a descrença nos registros orais como fontes que possibilitassem o acesso ao passado por ser difícil de identificar as distorções pelas quais esses registros passaram. Como resultado, a tradição oral foi vista por esses estudiosos como contos proferidos de geração em geração, como se essas populações não se valessem de recursos auxiliares para a preservação das tradições. Mais ainda, as tradições eram vistas apenas como artifícios morais ou didáticos ${ }^{154}$.Desse período até a década 1960 Vansina também identificou outras pesquisas feitas por historiadores, como o caso de J. D. Fage e R. Oliver. O primeiro, influenciado pela moderna antropologia social, enfatizou a relação entre a tradição oral e o desenvolvimento das sociedades, e ainda considerou que nenhuma avaliação pode ser feita amenos que se saiba a função que a tradição preencha e, por isso, quais distorções dela podem derivar. Oliver, por sua vez, pensou que a tradição oral tem frequentemente um valor para a investigação e que ela não é afetada pelos preenchimentos ou distorções nos relatos, de forma que não perde todo seu valor de fonte histórica. Mas, para seu valor histórico, só poderiam ser julgadas em comparação com evidencias arqueológicas para determinar se elas colaboram ou invalidam uma compreensão sobre o passado ${ }^{155}$.

\footnotetext{
${ }^{154}$ Vansina, Oral Tradition, p. 6.

${ }^{155}$ Idem, op. cit., p. 7.
} 
Já os etnólogos e antropólogos se depararam com outras questões relativas à utilidade de reunir tradições orais: seriam confiáveis? Poderiam conter alguma quantia de verdade? Qual sua função na dinâmica da sociedade? A maioria deles deu atenção à função que a tradição exercia dentro das sociedades nas quais eram transmitidas, como foi o caso dos fundadores da escola funcional estruturalista, Redcliffe-Brown e B. Malinowiski. EvansPritchard, outro funcionalista, também entendeu que as tradições orais eram uma representação coletiva do passado, aquilo que os antropólogos sociais chamaram mito. Naquela época, Vansina já ressaltava que a escola funcionalista pôs demasiado acento na função da tradição oral, visto que para aqueles não havia uma função histórica na tradição oral. Assim, os estudos se desenvolveram no campo dos costumes e das leis, e não na história. Mas essa visão não era sustentada por Evans-Pritchard, já que ele considerava a tradição oral e seu uso como fonte histórica mesmo se ela tivesse sua maior parte como “inconfiável”, uma vez que o historiador tem “qualidade de analise conjectural”, e que veracidade e construção do passado é sempre uma matéria de grau ${ }^{156}$.

De todo modo, os estudos etnográficos e históricos mostravam à época que o valor da tradição oral como evidência histórica era um problema a ser resolvido, mas apesar deles levantarem importantes questões, nenhum promoveu uma discussão geral sobre a natureza especial da tradição oral como uma fonte para informação sobre o passado, nem tentaram aplicar os métodos da crítica histórica para essas fontes como advogava Vansina ${ }^{157}$. De algum modo, ele enfrentou o estruturalismo nas análises sobre as sociedades congolesas, mas não conseguiu escapar ao relativismo cultural nem ao discurso instrumentalista, matéria que analisaremos pouco mais adiante revisitando The Kingdomof Savana.

O ponto chave de DelaTraditionOrale foi identificar as técnicas de preservação das tradições orais entre os Kuba no Congo - grupo com quem conviveu entre 1955 e 1956, e

\footnotetext{
${ }^{156}$ Vansina, Oral Tradition, p. 13.

${ }^{157}$ Idem, op. cit., p. 18.
} 
depois entre 1957 e 1960 - e outras populações estudadas na época pela antropologia. Vansina propôs que os métodos de transmissão podem seguir regras definidas. Ou seja, onde existe um método especial de técnicas é possível preservar a tradição confiavelmente e transmiti-la de geração a geração. E, independente do método, é mais provável que uma transmissão seja precisa se ela não for propriedade pública, mas formas esotéricas de conhecimento de um grupo especial ${ }^{158}$.

Um exemplo identificado por ele como técnica de preservação é a forma de instrução que cada sociedade sem recurso escrito encontra para transmitir conhecimento, algumas com instituições vinculadas ao estado, que determina o que deve ou não ser passado adiante (caso Asteca); outras onde o conhecimento é passado hereditariamente como com os baba elegun na Nigéria; e ainda, através de funções sociais de ensino sendo cada cargo responsável por um conteúdo distinto, como ocorre com os abiiru em Ruanda ${ }^{159}$. Outro exemplo de manutenção das tradições é quando sua transmissão acompanha uma série de sanções ou recompensas. São métodos cujo dever é saber se as histórias estão sendo recitadas de acordo ou não com o convencional. Em alguns grupos são aplicadas mais sanções do que recompensas, variando de pena de morte a ridicularização ${ }^{160}$. Algumas tradições, ainda, podem ser mantidas por conhecimentos esotéricos recitados por toda a população. Nesse caso, elas são transmitidas por pessoas vinculadas a uma instituição particular ou são propriedade de um grupo específico. Ninguém mais é autorizado a transmitir essas tradições, mesmo se for bem informado sobre a tradição. Entre os Kuba o direito da tradição é secreto e não pode ser transmitido por alguém de fora de um conselho de transmissão. Para Vansina, o exame da instrução para uma compreensão sobre a tradição oral por meio do controle exercido e da existência de tradições esotéricas revela o fato de que a tradição foi frequentemente transmitida de geração em geração por um método do qual se sabiam seus efeitos e quemuitas

\footnotetext{
${ }^{158}$ Idem, op. cit., 31-40.

${ }^{159}$ Vansina, Oral Tradition, p. 31-32.

${ }^{160}$ Idem, op. cit., p.33-34.
} 
sociedades sem escrita prestaram particular atenção no cuidado com a preservação e a transmissão dessas tradições ${ }^{161}$.

Todavia, as técnicas de manutenção das tradições não estavam apenas no campo verbal. Vansina revelou como a utilização de alguns objetos materiais, passados de geração em geração, contém certas memórias associadas a eles que facilitam rememorar a tradição. Essas técnicas que associam objetos a memórias coletivas ele chamou de "dispositivos mnemônicos”. Ele cita o exemplo do Peru, onde os Incas utilizavam uma espécie de telas com nós para contar ali a história de cada rei; no reino do Daomé pinturas eram usadas nos palácios para relembrar as histórias e no império Ashanti o trono era sempre rememorado com os que ali se sentaram. Essas técnicas mnemônicas são vistas por Vansina como grandes suportes na preservação da tradição. Segundo ele, ainda, não só objetos, mas os ritmos dos tambores em algumas regiões de África informam histórias de suas respectivas tradições, como no caso dos Dagomba, onde a história das casas reais é preservada pelos códigos dos tambores.

Com isso, um passo decisivo foi dado nos estudos sobre tradição oral. Ao entender a transmissão das tradições por vários meios e a utilização de instituições sociais para regular os métodos de transmissão, abriu-se ao historiador a possibilidade de avaliar em que medida o método de transmissão usado, para toda tradição particular, fornece circunstâncias favoráveis para uma eventual precisão do testemunho inicial no qual se baseia a tradição ${ }^{162}$.

Anos mais tarde, no entanto, Jan Vansina sente a necessidade de revisar alguns conceitos empregados na sua primeira obra. Afinal, os anos entre 1960 e 1970 foram um período em que os debates acadêmicosem torno do estruturalismo se fizeram mais presentes, com críticas e reajustes. Tanto dentro da história, com o grande prestígio da história social, quanto na antropologia influenciada por Levi-Strauss ou até na teoria literária com as críticas

\footnotetext{
${ }^{161}$ Idem, op. cit., p. 36.

${ }^{162}$ Vansina, Oral Tradition, p. 39.
} 
pós-estruturalistas de Roland Barthes e Jacques Derrida. Não obstante, seria inapropriado olhar apenas os debates acadêmicos em si. As independências em África e Ásia, as revoluções culturais, as ditaduras latino-americanas, a luta negra por direitos civis nos Estados Unidos e a Guerra do Vietnã: tudo contribuía para uma desilusão dos modelos explicativos estruturalistas. As memórias de Vansina sobre a época confirmam essa relação de produção acadêmica e mudanças sociais: “as pessoas estavam insatisfeitas com o marxismo ou qualquer teoria social apresentada como ‘verdade’”"163. Diante disso, as críticas ao estruturalismo foram severas, e os estudos culturais começavam a despontar como uma alternativa, com novos objetos e perspectivas. Por isso, Vansina não tarda rever Oral Tradition publicando, em 1985, Oral Tradition as History. Se no primeiro livro as críticas à corrente funcional-estruturalista eram mais discretas, no segundo elas são mais incisivas. E, ainda, levando em conta a influência da sociedade nas estruturas de preservação, ele mostra como as tradições orais também dizem sobre os aspectos culturais de um grupo.

A maior crítica de Vansina diz respeito à maneira que alguns sociólogos trataram as tradições. Não precisamente sobre a função da tradição na sociedade, mas o fato de tratá-la unicamente como produto da sociedade no presente ou tendo sua função exclusiva no presente. O exagero dessa interpretação seria o de não perceber as mensagens nas tradições orais como ponte entre passado e presente. Seu argumento em defesa da função da tradição preservar o passado baseia-se, fundamentalmente, nas formas de controle das tradições que cada grupo desenvolve, seja na interpretação e atuação do texto, nas instituições, nas formas sociais de controle da informação ou nas atribuições dos responsáveis por essa transmissão (domínio público ou privado). Portanto, para Vansina, esses métodos de preservação representam a importância que cada sociedade dá ao seu passado. A tradição não poderia ser uma forma exclusiva de atender às demandas presentes de uma sociedade "sem memória”,

\footnotetext{
${ }^{163}$ Whitehead \&Vansina, op. cit., p. 314.
} 
mas ao contrário, um artifício de manutenção e preservação das experiências ancestrais ${ }^{164}$. E, mesmo que as tradições sofram alterações durante o tempo, “essas mudanças não podem ser atribuídas apenas a forças sem face, mas ao resultado dos sonhos e ações das pessoas”165.

Mesmo assim, ele não minimizou os efeitos das configurações sociopolíticas nas tradições orais. Vansina levou em consideração que os modelos narrativos podem estar atrelados às formas sociais, como é o caso demonstrado numa análise comparativa entre os gêneros literários em Ruanda e Burundi, locais de uma proximidade linguística intensa que se diferenciam na organização política. No estudo comparativo feito durante sua pesquisa de campo na década de 1960 ele percebeu que, enquanto em Burundi o governo não é tão central, não havendo a necessidade dos governantes circunvizinhos estarem ligados por sangue ao rei, em Ruanda essa necessidade existe enquanto estrutura social. Por isso, o sistema político Rundi não favoreceria a memória histórica como em Ruanda - uma vez que eles não preservam a história de famílias importantes nem dos governantes provinciais, e ainda, não mantém a história de um governo central, por que a estrutura social não exige isso. Essa diferença sociopolítica entre Ruanda e Burundi expõe a diferença nos gêneros, na atitude em relação ao passado e no repertório do conteúdo nas mensagens ${ }^{166}$.

Nessa revisão Vansina também reconheceu os limites das tradições orais e sua transmissão mais do que no primeiro livro, cujo caráter era a defesa daquilo que não se imaginava fazer: história oral. Os limites estão numa congruência entre as estruturas de transmissão da tradição (e tradições em si) com a sociedade. Primeiro porque alguns grupos identificam, por exemplo, a história de um ancestral até a segunda geração anterior (como reino Tio no Médio Congo, em que a terceira geração é sempre identificada como Ngobila), o que dificultaria recobrar a história anterior a quatro gerações. Depois, porque a tradição é preservada devido a algum critério de importância ou significância. Porém, com o passar do

\footnotetext{
${ }^{164}$ Vansina, Oral Tratidon as History, pp. 95-108.

${ }^{165}$ Idem, op. cit., p.108.

${ }^{166}$ Vansina, Oral Tratidon as History, pp. 114-116.
} 
tempo os critérios mudam e ainda persiste um sistema de seleção. “Como resultado de cada processo de seleção, o conteúdo histórico intencional das tradições se torna próximo das preocupações sociais do passado e do presente” ${ }^{\text {"167 }}$.

Como já foi dito, após as críticas ao estruturalismo, os aspectos concernentes à cultura ganharam mais expressão. Logo, as mensagens nas tradições poderiam revelar aspectos de cada cultura e como a cultura é intrinsecamente ligada às tradições orais. Aquilo que ele considerou como aspectos básicos da cultura são conceitos básicos encontrados em todos os grupos humanos, por mais que variem suas concepções, como é o caso de espaço, tempo, número, realidade histórica e causa. As tradições seriam indícios, portanto, do modo como cada grupo entende ou percebe esses conceitos. É o caso apresentado sobre a tradição Maia, que divide o espaço a partir do centro em que se encontram. Acreditando possuírem quatro sucessivas criações cada uma mais perfeita que a outra, onde o centro mais puro é o local onde vivem, cada nova criatura foi empurrada para fora em direção à periferia ${ }^{168}$. Ou ainda, a tradição deliberativa entre os Kuba sobre verdade histórica, que ocorre da seguinte maneira: quando uma tradição está para ser relatada, o conselho ensaia uma primeira vez em sessão secreta, chamada kuum, e assim pode estabelecer mais uma vez o que é verdade. Como um antigo chefe contou para Vansina “o que um dia foi verdade agora é falso, e o que foi falso é verdadeiro" ${ }^{\text {169. }}$.

Enfim, refletir a tradição oral como aspecto revelador dos comportamentos humanos no tempo (como história) insere-a de vez numa alternativa para a produção de conhecimento histórico. Fazendo isso, Vansina evidencia como populações não produtoras de registros escritos interpretam, posicionam-se, refletem e transformam seu próprio conhecimento em relação ao passado. Mais ainda, sugeriu novas possibilidades do que seja a história e os conhecimentos relativos ao passado na tradição oral, não exclusivos a uma função presente

\footnotetext{
${ }^{167}$ Idem, op. cit., p. 119.

${ }^{168}$ Vansina, Oral Tratidon as History, pp.125-125.

${ }^{169}$ Idem, op. cit., p.130.
} 
como fizeram parecer os seguidores do funcional-estruturalismo. Por uma via, ao analisar as formas de transmissão dos registros orais, Vansina contribuiu para que se enxergassem os Kuba como produtores de sua história e consequentemente outras sociedades que não utilizam recursos escritos. Porém, os discursos nativistas e instrumentalistas sobre África não escaparam de suas análises, principalmente nas suas considerações sobre a história do Congo e Angola em The KingdomsofSavanna.

Depois do período do seu mestrado em Londres, Vansina havia se convertido quase que completamente aos estudos antropológicos,como ele mesmo confessa ${ }^{170}$. Mas essa situação muda ao conhecer Philip Curtin na década de 1950 durante sua segunda estadia em Ruanda. Nessa época, a crise política era latente: em 1959 a guerra pela independência havia começado e o Congo Belga também seguia para o mesmo caminho. Em meio à tensão de ser antropólogo belga em território colonial, Vansina recebeu uma ligação de Curtin, dos Estados Unidos, para ocupar a vaga como pesquisador na Universityof Wisconsin-Madison durante um período de três anos. Ali, o departamento de história estava em plena transformação graças às novas áreas de pesquisa e direção. Philip Curtin e Fred Harrington, que tinha se tornado presidente da universidade, haviam decidido que as pesquisas sobre o resto do mundo eram tão importantes quanto os estudos sobre Europa e América. Além do mais, o corpo docente na área de antropologia era diverso, com especialistas boasianos ou da tradicional antropologia social.

É, então, no contexto da Wisconsin-Madison que KingdomsoftheSavanna é escrito. A narrativa histórica se desenrola primeiramente com as origens do reino do Congo antes da chegada dos europeus, resgatada através das tradições orais. Vansina aponta o início do sistema político que durou quase cinco séculos como consequência da consolidação do reino com as conquistas de Nimi a Lukeni no século XIV e a centralização em Mbanza Kongo,

\footnotetext{
${ }^{170}$ Whitehead \&Vansina, Interview, p. 307.
} 
desmistificando as perspectivas de Ralph Delgado e Morais Martins que creditavam aos portugueses a implantação de um sistema político no Congo ${ }^{171}$. Para a historiografia lusonacionalista, as provas desse empréstimo estavam na conversão de Nzinga a Kuwu em 1491 e, principalmente, no códice de instruções de um regimento num acordo firmado entre Afonso I (filhos de Nzinga) e o rei português Manuel. Vansina, porém, foi o primeiro a questionar a interpretação desses documentos como provas de que o sistema político no Congo foi organizado pelos portugueses. Como ele nota, apesar de Afonso aderir aos princípios gerais do documento no ensino, nas técnicas militares e no trabalho missionário essas foram as partes que o interessavam. Muitas outras não foram sequer aceitas e acabaram desenrolando uma série de desentendidos entre as duas partes.

Para Vansina, o cumprimento do regimento foi perturbado inicialmente por Fernão de Mello, governador da ilha de São Tomé, que fez o possível para complicar as relações entre Portugal e Congo (inclusive usurpando presentes do rei congolês) com o intuito de ganhar vantagens nas mediações entre as duas coroas. Por outro lado, Afonso I percebeu serem sempre mais vantajosos os acordos para os portugueses, uma vez que todos os serviços prestados pelos lusitanos eram cobrados na forma de trabalho humano escravizado e que Portugal intentava impor um monopólio comercial na região. Com a morte de Afonso, duas configurações se apresentavam para o reino do Congo: de um lado os portugueses da ilha de São Tomé apoiando Dom Pedro I, um dos parentes de Afonso; e de outro, a população de Mbanza Kongo apoiando o seu neto Dom Diogo I com os portugueses mais fiéis à coroa ${ }^{172}$.

Assim, na narrativa histórica o papel que os portugueses assumem é o de agentes desestabilizadores das políticas congolesas. Sejam por interesses pessoais como os partidários da ilha, ou em favor da coroa lusitana no caso dos habitantes de Mbanza Kongo. Nessa base interpretativa é onde se identifica o discurso instrumentalista sobre África, ou seja, permeado

\footnotetext{
${ }^{171}$ Vansina, Kingdoms of the Savanna, p. 41.

${ }^{172}$ Vansina, Kingdoms of the Savanna, pp. 49-57.
} 
de voluntarismo e vitimização - talvez mais sintomático em discursos políticos como os de KwameNkrumah ou Amilcar Cabral, ou ainda, em narrativas históricas enfáticas no processo de desmantelamento dos sistemas políticos africanos por meio da inserção na economia de $\operatorname{mercado}^{173}$.

Mas afinal, quais seriam os prejuízos de tal análise? Para AchilleMbembe, esses discursos reduzem a história da África numa série de “fenômenos de sujeição interconectada em uma continuidade compacta” ${ }^{174}$. Ou seja, as forças serão sempre adversas na tentativa do desenvolvimento do “eu africano”. Consequentemente, a África não seria responsável pelas calamidades infligidas sobre ela mesma e assim a sua situação atual não poderia derivar de escolhas autônomas. Essa visão reificada da história africana, onde as causalidades são atribuídas a entidades invisíveis traz à tona também a temática filosófica hegeliana da identidade e da diferença polarizada nas relações senhor/escravo ${ }^{175}$.

A expropriação e o desmantelo material infligidos no processo de desapropriação de ordem jurídico-econômica teria singularizado a experiência africana de submissão “caracterizada pela falsificação de si pelo outro, seguindo-se o estado de exterioridade máxima e de empobrecimento ontológico que daí adviriam” ${ }^{176}$. E nesse caso, perde-se a autonomia sobre sua própria história e sobre “se-ter-a-si-mesmo no mundo"177.

Paralelamente, aquilo que AchilleMbembe chama de "prosa do nativismo" é igualmente identificável em KingdomsoftheSavanna. Sua perspectiva histórica das populações congolesas e angolanas é quase atemporal, abrangendo quatro séculos entre 1500 e 1900. Ao analisar as estruturas culturais, políticas e sociais, suas referências são sempre estudos antropológicos do século XX, por conseguinte, há uma projeção da situação presente

\footnotetext{
${ }^{173}$ É o caso das análises de David Birmingham em Trade andConflict in Angola, livro de 1966. Onde apresenta, sob uma perspectiva marxista os conflitos entre portugueses e mbundus.

${ }^{174}$ Mbembe, As Formas Africanas de Auto-Inscrição, p. 175.

${ }^{175}$ Mbembe, As Formas Africanas de Auto-Inscrição, 176.

${ }^{176}$ Idem, Crítica da Razão Negra, p. 140.

${ }^{177}$ Idem, ibid.
} 
dessas populações em relação ao passado. Ou seja, as mudanças nessas sociedades são imperceptíveis e os mbundu, bakongo ou ovibundu do século XV são interpretados como sendo quase os mesmos dos fins do século XIX e início do XX. Como vimos (Capítulo 1), a não coetaneidade dos tempos históricos é um dos instrumentos do poder-saber colonial que demarcava a diferença ontológica entre europeus e africanos. Uma das principais características desse tipo de pensamento era exatamente uma tensão estrutural:

[...] opondo uma tendência universalizante que afirmava o pertencimento à condição humana (igualdade) à outra, particularista, que enfatizava a diferença e a especificidade, frisando a não originalidade, mas o princípio da repetição (tradição) e os valores autóctones ${ }^{178}$.

Assim, ao colocar o tempo dessas populações como quase imutável e frisar o princípio da tradição, reforçam-se a diferença e a particularidade. E mais uma vez, uma humanidade a parte, cujos signos são o Negro e a África, é apresentada nas ciências sociais e humanas como dados objetivos.

Mas a influência do discurso antropológico não se restringe apenas à abordagem interpretativa dos desdobramentos sociais dessas populações. Metodologicamente, as fontes missionárias são vistas por Vansina com uma dose de relativismo cultural, “elas recordam eventos vistos pelos olhos estrangeiros, que frequentemente estavam em conflito com as populações locais” ${ }^{179}$. Por isso, cada fonte deveria ser avaliada pelo possível viés gerado da posição pessoal de quem escreveu antes dos dados serem utilizados como prova. Vansina se coloca como locutor imparcial, e essa imparcialidade é dada pela fusão com o Outro - “elas recordam eventos vistos por olhos estrangeiros" - como se seus olhos fossem o dos kuba, mbumdu ou bakongo. Dessa forma ele justifica uma seleção contraditória de fontes descartando os registros missionários do século XVII, mas por outro lado, sem abrir mão das

\footnotetext{
${ }^{178}$ Mbembe, As formas Africanas de Auto-Inscrição, p. 182.

${ }^{179}$ Vansina, The Kingdom of the Savana, p.7.
} 
referências dos trabalhos de Louis Jadin e Jean Cuvelier, sabidamente missionários durante a ocupação do Congo Belga.

Vansina dá preferência às etnografias antropológicas contemporâneas em detrimento das produzidas na Era Moderna. Sua justificativa é de que esses testemunhos eram etnocêntricos, com conhecimento superficial das culturas e sociedades, por fim, "suas descrições não devem ser tomadas como representando a realidade dos tempos” ${ }^{180}$. Já os estudos etnográficos parecem fazer uma "pesquisa mais essencial”181, ou seja, da fusão do Eu com o Outro é possível se chegar num conhecimento mais objetivo. É possível que a busca por um conhecimento mais objetivo em relação a essas populações esteja ligado a um tipo de humanismo específico, apontado por Mudimbe como uma das raízes da diferença. Um humanismo que pensa que "para conhecer o Homem (com letra maiúscula), é indispensável conhecer as variedades, as diferenças e as semelhanças do homem”182.

Esses discursos tanto em relação ao nativismo quanto em relação a metodologia e uso das fontes missionárias é perceptível na obra de John Thornton. A diferença, como veremos a seguir, é que o veio antropológico estruturalista herdado por Thornton provém da própria história nos termos da “longa duração” de Braudel. E mesmo tentando escapar de uma interpretação voluntarista e instrumentalista dos processos históricos africanos - tirando a ênfase da influência portuguesa no declínio do reino Kongo e colocando acento nos processos internos entre Mbanza Kongo e Nsoyo - ele reforça o discurso nativista na análise da relação entre cosmologia bakongo e europeia.

\subsection{John Thornton: as inflexões herdadas do estruturalismo braudeliano.}

\footnotetext{
${ }^{180}$ Idem, op. cit., p. 8.

${ }^{181}$ Idem, op. cit., p. 13.

${ }^{182}$ Mudimbe, op. cit., p.78.
} 
A obra de John K. Thornton é tida como referência obrigatória para os interessados na história do Congo e Angola. Com trabalhos extensos e diversos, que abarcam o início do século XV até meados do século XVIII, ele se preocupou em entender tanto as relações políticas no Kongo ${ }^{183}$ como também a contribuição africana no mundo atlântico ${ }^{184}$, e ainda, movimentos religiosos no interior da região ${ }^{185}$.

Sua visão em relação à desintegração do reino do Kongo durante o século XVII não é pensada a partir dos efeitos da colonização, mas antes como decorrência das configurações sociais, econômicas e políticas que colocavam em conflito crescente uma "aristocracia urbana” - cujo centro era Mbanza Kongo - e as populações interioranas. Na introdução do seu primeiro livro, por exemplo, sua posição é de que a história tem tratado a escravidão e o estabelecimento dos portugueses como as causas primeiras do declínio do reino do Kongo, quando na verdade para ele as "mudanças ocorridas no Kongo foram muito mais o produto das dinâmicas internas do que a simples reação de pressões externas”186. Por isso também, no decorrer do livro os anos entre 1641 e 1665 são importantes, especialmente porque com a vitória de Luanda sobre o Kongo, ao final desses anos, é garantido o poder e a autonomia do Nsoyo como força independente frente aMbanza Kongo ${ }^{187}$.

Já ao que se refere à assimilação da religião cristã é onde transcorre o maior número de críticas à sua obra. Ele acredita que o cristianismo, ao se tornar religião oficial por meio do batismo, forneceu os instrumentos que permitiram a legitimação do poder central em torno do maniKongo e sua elite urbana ${ }^{188}$. Insistindo na ideia de que as noções cristãs foram renomeadas, esse autor pressupõe uma aproximação entre cosmologias europeias e bantas que, em decorrência, lhe possibilita nomear as experiências religiosas na África Central como

\footnotetext{
${ }^{183}$ Thornton, The Kindgom of Kongo

${ }^{184}$ Heywood \&Thornton, Central Africans, Atlantic Creoles, and Fundation of the Americans, 1585-1660.

${ }^{185}$ Thornton, TheKongolese Saint Anthony.

${ }^{186}$ Thornton, The Kingdom, p. xv-xvii.

${ }^{187}$ Idem, op. cit., p. 76-83.

${ }^{188}$ Idem, op. cit., p.57.
} 
“Cristianismo Africano”. Ora, se por um lado essa ideia ignora a coexistência de duas identidades religiosas diferentes, como tem alertado James Sweet ${ }^{189}$, por outro abdica da predominância de práticas endógenas nos processos de mudança social na África ${ }^{190}$. É possível dizer que a ideia de John Thornton tenha raízes nos seus marcos teóricos que eram à época: “as recentes abordagens histórico-marxistas de aproximação antropológica, e uma "história total” do tipo pregada, e geralmente praticada, por Fernand Braudel e a escola dos Annales"191.

Ao recusar múltiplas identidades religiosas em detrimento de um “Cristianismo Africano”, ele se aproxima do estruturalismo caro às análises broudelianas de um "tempo quase estacionário, em que passado presente e futuro não mais diferem e se reproduzem sem descontinuidade» ${ }^{192}$. Em outras palavras, ao concentrar práticas cristãs e bakongo no conceito de “Cristianismo Africano”, Thornton descobre a fórmula, já anunciada no seu prefácio, para a “explicação de um quadro teórico que se torna aplicável para além de algumas centenas de milhares de quilômetros quadrados em África Central.”193. Como veremos, a história da África de Thornton serve para explicar os processos pelos quais a cultura afro-americana se perpetuou nos Estados Unidos, e mesmo que sua concepção de “Cristianismo Africano” tenha sofrido alterações, essa ideia persiste inclusive em obras mais recentes, como em Central Africans, AtlanticCreolesand Foundation oftheAmericas, 1585-1660,publicado em 2007.

As bases teóricas utilizadas por Thornton, no caso a história da longa duração de Fernand Braudel, surgiram no contexto de defesa do espaço acadêmico da história como disciplina diante da antropologia estruturalista de Lévi-Strauss na década de 1950. Ao explicar o surgimento desse modelo teórico na história, podemos compreender como a antropologia estruturalista tem sua parcela de influência nas obras do historiador.

\footnotetext{
${ }^{189}$ Sweet, Recriar África.

${ }^{190}$ Almeida, Uma Infelicidade Feliz, p. 17.

${ }^{191}$ Thornton, The Kingdom, p. ix.

${ }^{192}$ Delacroix, Dosse\& Garcia, Correntes Históricas,p. 230.

193 Thornton, The Kingdom, p. x.
} 
Na Europa, a crise do evolucionismo no pós-Segunda Guerra fora sentida de forma a refletir a utilidade das ciências sociais e humanas. Assim, uma rede de sociólogos e etnólogos pôs-se na disputa com historiadores num momento em que a Fundação Rockfeller se dispunha a investir nas pesquisas em ciências sociais na Europa ${ }^{194}$. Logo, abria-se uma série de justificativas e de ataques para se definir qual das ciências seria mais proveitosa na compreensão dos acontecimentos sociais.

A história viu-se ameaçada pelas críticas da antropologia estrutural de Strauss. Por observar apenas empiricamente o real sem criar modelos, o historiador estaria condenado a uma ciência informativa, sem função na observação das estruturas sociais. Frente a essas acusações, a estratégia de Braudel era deter a ofensiva das ciências sociais de duas formas.

Primeiro através da estruturação e consolidação do espaço acadêmico, formando um grupo e uma rede concisa de pesquisadores através do Centre de RecherchesHistoriques(em 1949) ${ }^{195}$ e elaborando um programa que se baseava nas áreas studies das universidades americanas em colaboração com Clemens Heller, que as adaptou ao modelo francês. O programa tentava permitira colaboração entre diferentes disciplinas visando a compreensão do mundo contemporâneo através do passado numa espessura temporal de longa duração. "O projeto recebe adesão da Fundação Rockfeller, depois de um ano de negociações difíceis”196. Assim, o número considerável de novos centros de pesquisa em história são erigidos, primeiro o dedicado à África em 1956 (não por acaso durante a Guerra da Argélia), depois os dedicados à Índia, China, Rússia, Europa oriental e Turquia ${ }^{197}$. Juntamente com esse programa, "assistimos um aumento espetacular no número de diretores de estudos: 32 em 1951, são 67 em 1957, 84 em 1961, para chegarem a 110 em 1966”,198. Com essa

\footnotetext{
${ }^{194}$ Delacroix, Dosse\& Garcia, op. cit., p. 203.

${ }^{195}$ Delacroix, Dosse\& Garcia, Correntes Históricas, p. 207.

${ }^{196}$ Idem, op. cit., p. 208.

${ }^{197}$ Idem, op. cit., p. 209.

${ }^{198}$ Idem, op. cit., p. 209.
} 
consolidação na estrutura acadêmica, a revista dos Annales era vista como capaz de responder as demandas sociais que a história “tradicional” não poderia cumprir.

A segunda estratégia de Braudel era no âmbito teórico, numa aproximação com o estruturalismo antropológico de Levi-Strauss, derrubando as muralhas que cada uma das disciplinas criou. Para isso, reforçou a crítica às histórias événementielles e criou o conceito de longa duração (oposto ao do tempo curto, tempo do evento). Retomou um diálogo com a metodologia das ciências sociais sobre a influência da escola geográfica francesa de Demangeon e de Martonne, tirando “do ensinamento deles a intenção de desacelerar ao máximo o ritmo da história” ${ }^{99}$. Com isso, tripartiu o tempo histórico em eventual, conjuntural/cíclico e a longa duração. O convite dessa união com outras ciências sociais é apresentado num artigo da edição n4 da revista dos Annales, de 1958:

Falarei, pois, longamente da história, do tempo da história. Menos para os leitores dessa revista, especialistas em nossos estudos, que para nossos vizinhos das ciências do homem: economistas, etnógrafos, etnólogos ou (antropólogos), sociólogos, psicólogos, linguistas, demógrafos, geógrafos, até mesmo, matemáticos sociais ou estatísticos - todos vizinhos que, há longos anos, seguimos nas suas experiências e pesquisas porque nos parecia (e ainda nos parece), que, colocada a seu reboque ou ao seu contato, a história se ilumina com uma nova luz ${ }^{200}$.

Já a tripartição do tempo é indicada em O Mediterrâneo, iniciando com uma história quase imóvel, história das relações entre o homem e o espaço geográfico numa integração do espaço com tempo. Em seguida, apresenta a história lenta e dos ciclos sociais e econômicos. Por fim, uma história eventual nos moldes do que ele denominava história tradicional. Esse casamento das ciências históricas com o estruturalismo foi bem-sucedido, manteve a posição da história enquanto instituição acadêmica e ao mesmo tempo garantiu seu lugar de importância diante das demais ciências sociais, com o preço de alterar significativamente os

\footnotetext{
${ }^{199}$ Idem, op. cit., p. 222.

${ }^{200}$ Brauldel, Escritos sobre a História, p. 44.
} 
preceitos teóricos da história que até então era mais atrelada às análises conjecturais. Como analisa Delacroix, Dosse e Garcia: “Tendo a história se tornado antropológica, a antropologia tornar-se-á histórica. Fernand Braudel terá, assim, preparado as inflexões do discurso histórico da terceira geração dos Annales”201.

Quando essas inflexões são herdadas por John Thornton e aplicadas na construção de uma história do Congo, vemos os desdobramentos numa interpretação nativista da cosmologia bakongo, além de um trabalho metodológico com pretensa objetividade através do relativismo cultural. Recentemente, argumentou-se que a perspectiva de Thornton das similitudes culturais, da mudança da "alteridade para a semelhança, da tradução para incorporação [...] ocorreu e apenas foi possibilitado, em nossa concepção, pela recusa do uso instrumental antropológico pelo autor”202. Porém, veremos o contrário. O uso do instrumental antropológico ocorreu através da história estruturalista e antropologizada de Braudel.

Assim como em O Mediterraneo, a geografia assume um lugar importante em The Kingdomof Kongo com um primeiro capítulo dedicado ao cenário natural congolês. Afinal, os desenvolvimentos naturais no Congo não incluem apenas forças inorgânicas como rochas, ventos e chuvas, “os congoleses partilham suas terras com uma série de formas de vida”203. Nessa relação do homem com seu meio, o historiador procura explicar as estruturas sociais, históricas e políticas numa passagem do determinismo biológico para o geográfico. Aliás, quando Braudel justifica essa aproximação da história com a geografia, tecendo elogios ao livro de MaximilienSorre - Les bases biologiques de La Géographiehumaine, essai d’une écologie de l'homme -, ele o faz exaltando exatamente essa passagem de um determinismo ao outro:

\footnotetext{
${ }^{201}$ Delacroix, Dosse\& Garcia, Correntes Históricas, p. 231.

${ }^{202}$ Sapede, Muana Congo, MuanaNzambi a Mpungu, p. 61.

203 Thornton, The Kingdom, p. 11.
} 
Não reside aí, com as cautelas que advinham (particularmente num geógrafo da escola francesa), a pesquisa de um determinismo biológico - ao menos dos limites e das coerções inegáveis desse determinismo? [...] O homem biológico não é desconhecido, nós o sabemos. Não é tampouco um recém-chegado, no campo da geografia, mas jamais fora aí introduzido com essa minúcia, esse gosto pela exatidão científica, esse cuidado por problemas bem formulados e por investigações claramente concebidas, conduzidas como experiências onde tudo é longa, objetivamente descrito, notado e explicado. Aí reside não só a originalidade, mas o grande mérito desse livro ${ }^{204}$.

A definição de padrões comportamentais ou estruturas mentais a partir do local geográfico é uma das tônicas em outras obras de Thornton. Em Central Africans, AtlanticCreolesand Foundation oftheAmericas, 1585-1660, por exemplo, aponta a intenção do estudo em explorar as origens dos centro-africanos que chegaram as Américas definindo “seus papeis como fundadores e criadores da cultura afro-americana” ${ }^{205}$. Para Thornton, ainda, a África Centro-Ocidental “compartilha bastantes semelhanças nas formas linguísticas, sociais, culturais e políticas, tornando-a muito mais uniforme no conjunto de crenças e práticas do que qualquer outro lugar da África Ocidental”206. Assim, ao atravessar o Atlântico, essa cultura coesa fornece as bases da cultura afro-americana por herança. Se as visões de Thornton escapam de um instrumentalismo, já que as mudanças que ocorreram no Congo foram muito mais um produto das dinâmicas internas do que uma simples reação às pressões externas ${ }^{207}$, elas reforçam o discurso nativista através da análise das estruturas sociais e do universo mental "centro-africano" que se manteve bastante fiel durante todo o século XVII ${ }^{208}$. Aliás, como destaca Mbembe:

Desde o século XIX, aqueles que afirmaram que os africanos têm sua própria identidade cultural, que há uma autonomia especificamente africana, resolveram encontrar uma denominação geral e um lugar onde

\footnotetext{
${ }^{204}$ Braudel, Escritos, p. 145.

${ }^{205}$ Heywood \& Thornton, CentralAfricans, p. 1.

${ }^{206}$ Idem, op. cit., p. 49.

${ }^{207}$ Thornton, The Kingdom, p. xvii.

${ }^{208}$ Idem, op. cit., p. 67-68.
} 
ancorar sua prosa. O local geográfico foi aÁfrica tropical, definida como fronteira totalmente ficcional, cuja meta era abolir a fantasmática anatomia inventada pelos europeus e por Hegel e outros ${ }^{209}$.

Daí, a intrínseca relação entre o conceito de raça e geografia desemboca na buscade uma africanidade sintetizada em comportamentos e traços culturais específicos de um lugar: "tornando-se a geografia o lugar eleito para as instituições e o poder da raça se fortalecerem” ${ }^{210}$. Identidade cultural e territorialidade foram e continuam sendo discursos para autenticidade, a singularidade e a tradição de uma raça. Essa convicção da origem da nação calcada na raça retoma uma "genealogia intelectual fundada na territorialização da identidade, por um lado, e na racialização da geografia, por outro”"11 e por mais que se abandone o verbete "raça”, continua-se operando o conceito em outras formas.

Ao mesmo tempo, se África Central é eleita enquanto objeto por sua capacidade de explicar os processos de formação da cultura afro-americana (ou americana) graças ao quantitativo de escravizados chegados dessa região, isso faz dela um objeto para a busca da compreensão do Mesmo. Ou seja, uma história de África que serve mais à América do Norte, que “comenta-se a si própria a partir de dentro de um modelo cultural paradigmático”212.

Talvez, a intenção de Thornton tenha sido justamente criar mais similitudes entre os universos cosmológicos europeus e bakongos, compactando essas duas estruturas no conceito de uma mentalidade única e híbrida chamada "Cristianismo Africano". Mas um problema reside no fato dessa estrutura explicar as origens do comportamento afro-americano para um tipo específico de crença, como se essas estruturas mentais fossem perpetuadas entre os negros (pelo fato de serem negros) quer de um ou de outro lado do Atlântico. Uma problemática próxima da etnofilosofia, que se coloca como uma disciplina mais autoconsciente do que a inconsciência dos nativos, e além disso como destaca Hountondji,

\footnotetext{
${ }^{209}$ Mbembe, As Formas Africanas, p. 184.

${ }^{210}$ Mbembe, Crítica da Razão Negra, p. 160.

${ }^{211}$ Mbembe, Crítica da Razão Negra,162.

${ }^{212}$ Mudimbe, A Invensão de Africa, p. 39.
} 
baseia-se "na ideia de que, nas sociedades de pequena escala ou sociedades primitivas, como são chamadas, vigora uma total unanimidade, com toda a gente a concordar, por assim dizer, com toda a gente" ${ }^{213}$.

Para Thornton, o “Cristianismo Africano” desenvolvido no Congo, Angola e outras regiões do que ele chama África Centro Ocidental foi o "elemento mais visível da cultura Crioula Atlântica” ${ }^{214}$. E ainda, essa região teve uma influência maior na formação da cultura crioula nas Américas por se apresentar como um grupo humano mais conciso, “eles falavam apenas duas línguas Bantu muito próximas, kikongo e kimbundu” 215 e o aparato cultural comum incluía “um engajamento com o Cristianismo” ${ }^{216}$. Assim, mesmo que a intenção seja de procurar as similitudes cosmológicas entre grupos diferentes, o objetivo final é mostrar como esse sincretismo foi a base de uma tradição no outro lado do Atlântico. Uma cultura própria, de origem geográfica específica é invocada para dar visibilidade particular e mais uma vez cria-se a figura particularista do Outro em relação ao Mesmo.

Além disso, as consequências da abordagem estrutural histórico-antropológico de Thornton não se restringem às interpretações dos acontecimentos. Metodologicamente, sua relação com as fontes contém uma pretensa busca pela verdade, pela posição relativa ao objeto e, assim como em Vansina, a crença que por meio da exclusão dos discursos etnocêntricos dos missionários é fácil atingir a reconstrução de uma história puramente africana. Ao diferenciar-se de Anne Hilton, argumentando que a historiadora utilizou descrições da moderna cosmologia congolesa, ele define seu objeto como "mais fácil e menos perigoso, pois pretendo envolver apenas um número mínimo de julgamentos parciais de

\footnotetext{
${ }^{213}$ Hountondji, Conhecimento de África, conhecimento de Africanos: Duas perspectivas sobre os Estudos Africanos, p. 154.

${ }^{214}$ Heywood \& Thornton, op. cit., p. 170.

${ }^{215}$ Heywood \& Thornton, op. cit., p. 238.

${ }^{216}$ Idem, ibid.
} 
forasteiros [outsiders]"217. Coloca-se na posição de um não outsider e, ao fazê-lo, converte o Eu no Outro.

Isso fica mais evidente em duas resenhas críticas sobre os registros do missionário capuchinho Giovanni AntonioCavazzi, integrante de missões no Congo entre 1654 e 1667 e 1673 e 1676, cujos extensos relatos são amplamente utilizados na historiografia.

A primeira resenha, New LigthonCavazzi'sSeventeenth-CenturyDescriptionof Kongo, escrita em 1979, aborda a grande descoberta da época: um manuscrito, pertencente à família Araldi, produzido pelo missionário entre os anos de 1654 e 1667, tempo em que esteve pela primeira vez em África. E a segunda, Cavazzi, Missione Evangelica: General Introduction, fruto de uma tradução para o inglês do Volume A desse manuscrito disponível para leitura online.

Em New LigthonCavazzi’sSeventeenth-CenturyDescriptionof Kongo, Thornton se preocupa em descrever os processos pelos quais o documento chegou até nós, tentando fazer uma conexão entre o manuscrito e a obra impressa de Cavazzi. Inclusive, em sua opinião, “o relato é importante para os historiadores, não tanto pelo que Cavazzi viu por ele mesmo, mas pelo notável material perdido no livro”218, ignorando assim a ótica do missionário em detrimento das narrativas sobre os acontecimentos relativos às populações africanas, uma forma de análise que desconsidera o etnocentrismo das fontes em detrimento da informação dos acontecimentos reais.

Já na segunda resenha crítica, essa postura de Thornton aparece de forma mais concreta, mesmo porque ela é grafada depois de toda sua carreira estabelecida. Nela o historiador classifica Cavazzi como “anti-africano” sem fazer uma crítica mais apurada, atribuindo esse fator à personalidade do missionário:

\footnotetext{
${ }^{217}$ Thornton, The Kingdom, p. 58-59.

${ }^{218}$ Thornton, New Ligth on Cavazzi's Seventeenth-Century Description of Kongo, p. 260.
} 
[...] Cavazzi foi essencialmente anti-africano no seu olhar. Os viajantes europeus do século XVII tinham uma ampla gama de reações à África Central, dependendo de suas origens e perspectivas, bem como a situação específica que encontravam-se em África. Visualizado a partir do amplo espectro de opiniões, Cavazzi estava entre os mais negativos. Suas visões eram suficientemente extremadas [... ${ }^{219}$.

No fundo, são essas visões e esses pontos de vista, acompanhados das práticas missionárias, que podem nos dizer sobre as relações e as construções assimétricas entre europeus e africanos. Ao descartar a análise do euro-centrismo nas fontes, Thornton abdica da compreensão dos processos endógenos entre africanos e europeus. Por conseguinte, ignora os discursos enquanto práticas e, ao mesmo tempo, insere-os tão somente no plano da escrita e das ideias. De modo que, sendo essas ideias eurocêntricas, não poderiam contribuir para a formulação do que seja uma teoria dos processos históricos “essencialmente” africanos. E, ao final, retornamos à busca pela natureza centro-africana dentro da relação do historiador, pesquisa, objeto e fonte.

Por fim, o signo desse nativismo em Thornton é o conceito de Cristianismo Africano, um sistema de pensamento que ao ser adotado de forma pacífica ${ }^{220}$ formou as bases do pensamento crioulo atlântico - ou seja, de todos os negros, de um ou de outro lado do oceano. Na sua análise teológica, onde o cristianismo se torna o cristalizador de grupos africanos próximos por meio de uma entrega mágica à fé e da catequização inclusiva ${ }^{221}$, faltou-lhe a percepção da coerção simbólica. Posto que uma hegemonia estende seu controle não apenas por meios materiais, mas através de um sistema de disposições às práticas que pode definir o mundo dos partícipes desse sistema simbólico comum ${ }^{222}$.

\footnotetext{
${ }^{219}$ Idem, Cavazzi, MissioneEvangelica, p.11.

${ }^{220}$ Thornton, The Development of an African Catholic Church in the Kingdom of Kongo 1491-1750, p. 154.

${ }^{221}$ Idem, op. cit.,p.152-153.

${ }^{222}$ Mbembe, A África Insubmissa, p. 28.
} 


\subsection{Carlos Almeida e a reflexão do habitus nos processos endógenos entre africanos e europeus.}

Há, contudo, estudos recentes situados na contracorrente das perspectivas de Thornton e que se apresentam como diferentes, quer nas bases teórico-metodológicas, quer na interpretação das práticas de difusão do cristianismo no Congo. James Sweet, por exemplo, repensa a relação de congoleses e angolanos com o cristianismo durante o comércio Atlântico de escravizados entre os séculos XV e XVIII apontando as práticas mágicas, utilizadas por essas populações no Brasil na resistência ao escravismo, como um indicativo da dupla pertença religiosa e não como uma única cosmovisão fundida de elementos europeus e africanos.

Já Carlos Almeida demonstrou através do estudo das missões jesuítas e capuchinhas no Congo e na região mbundu, entre os séculos XVI e XVIII, como os processos de cristianização nada tinham de pacíficos, notando a queixa dos missionários em relação à “indocilidade” africana como indício da resposta criativa dessas populações ao processo cristianizador.

Apesar da obra de Almeida ser recente e sua tese de doutorado estar disponível apenas sob consulta direta, a selecionamos para análise por constituir um embate mais conciso às visões de Thornton. Principalmente por compreender a difusão do cristianismo no Congo e Angola através dos mecanismos de violência física e simbólica, onde ideias e ações se imiscuem nas disposições práticas do que seria aquele universo de missionação descrito nos relatos. Seu principal trabalho, Uma Infelicidade Feliz: A imagem da África e os Africanos na Literatura Missionária sobre o Kongo e a região mbundu (meados do séc. XVI - primeiro quartel do séc. XVIII) têm uma preocupação tripla. Primeiro, busca entender as relações entre os relatos dos missionários que chegam a Europa e as imagens já existentes sobre a região da 
África Central, questionando as rupturas, continuidades e contribuições para uma eventual transformação das ideias dominantes. Depois, no caminho de uma tradição intelectual cujo precursor foi Norbert Elias ${ }^{223}$, aponta a dimensão do disciplinamento social incluso no empenho da missionação e que "se traduzia na interiorização, pelos indivíduos, de um conjunto de regras e princípios de conduta considerada civil”224. E, finalmente, assinala o método de ação dos missionários na região e suas relações com a presença secular europeia; comparando os modelos jesuítas e capuchinhos, ao mesmo tempo em que revela formas endógenas de fixação de ambas as ordens.

Aqui, como no caso de Thornton, percebemos uma relação entre o marco teórico e a metodologia na análise das fontes missionárias. Em Almeida, essa influência de teorias é diversa e quase sempre provém de autores cuja teoria se relaciona com as respostas dadas ao estruturalismo. Ele pensa à luz de Norbert Elias e Bourdieu para a compreensão da difusão de padrões de comportamentos civis e habitus entre as dinâmicas europeias e africanas ${ }^{225}$. Utiliza V. Y. Mudimbe, E. Said e M. Foucault para entender os discursos como um conjunto de condições de existências pelos quais os missionários se projetam sobre o outro e sobre si mesmos $^{226}$. E ainda, justapõe Marry Louise Pratt para entender, no contexto da África Central - onde o contato com europeus por vezes foi descontínuo - o que ela denominou de zona de contato e transculturação, normalmente expressas em escritosauto-etnográficos e onde os “sujeitos colonizados empreendem sua própria representação, de maneira que se comprometem com os termos do colonizador” ${ }^{227}$. Um dos exemplos desses escritos auto-

\footnotetext{
${ }^{223}$ Judeu alemão refugiado na Inglaterra durante os anos 1930, os conceitos de Elias ficaram a parte dos debates acadêmicos até os anos de 1970. Com a obra ÜberdenProzess der Zivilisation, de 1939, se tornou o primeiro a empregar o conceito de habitus para explicar os processos conscientes e inconscientes nos processos de transformação das relações humanas. E, como aponta o historiógrafo Jurandir Malerba, ele "pensou estruturas sociais e conflitos de classe, mas nem por isso foi marxista. Ele pensou a ação racional, nem por isso foi weberiano. Se ele pensou na formação da personalidade, em termos da construção do habitus, tampouco foi freudiano". Ver: Malerba, A Influência Intelectual de Norbert Elias, p.60.

${ }^{224}$ Almeida, Uma Infelicidade Feliz, p. 24.

${ }^{225}$ Almeida, Uma Infelicidade Feliz,. 24, 325.

${ }^{226}$ Idem, op. cit., pp. 26-28, 324.

${ }^{227}$ Pratt, Ojos Imperiales, p. 35.
} 
etnográficos utilizados por Almeida é a petição de Lourenço da Silva Mendonça, mulato presumivelmente nascido no Brasil, e que reclamava à Sagrada Congregação de Propaganda Fide em 1685 contra o título de escravização perpétua a que eram submetidos os africanos cativos mesmo estes sendo batizados ${ }^{228}$.

Considerando o cristianismo nas sociedades africanas pós-coloniais, Mbembe destaca a necessidade de introduzi-las "na análise política do facto religioso, enquanto dotadas da capacidade inventiva que exercem”. Afinal, referir-se à “indisposição” das sociedades africanas ao cristianismo é afirmar que elas não foram ou são passivas no processo de estabelecimento da preeminência europeia ${ }^{229}$. É claro que os contextos históricos da África pré e pós-colonial são distintos, mas não se deve tratar o papel religioso como secundário em ambos os casos uma vez que a religião não é isenta às mudanças. Na verdade a importância reside justamente aí, as mudanças “operam-se continuamente no seio das próprias religiões" ${ }^{230}$.

Tratar com acuidade dos processos endógenos de cristianização em África - e no caso das historiografias analisadas, o Congo e Angola dos séculos XVI ao XVIII - é, portanto, não perder de vista que a imposição da hegemonia:

[...] caracteriza-se pela inculcação do que Bourdieu chama o "habitus", ou seja, um sistema de predisposições à prática, predisposições adquiridas pela experiência. Ora, em grande parte, o cristianismo é uma modalidade de proclamação da "verdade”, ou seja, uma determinada forma de construir mental e praticamente as realidades deste mundo e do outro, tornando-se assim um operador histórico. ${ }^{231}$

É nesse sentido que Almeida observa os processos de difusão do cristianismo, provando que mesmo os capuchinhos - tidos na historiografia como representantes de uma

\footnotetext{
${ }^{228}$ Almeida, op. cit., p.776.

${ }^{229}$ Mbembe, África Insubmissa, p. 29.

${ }^{230}$ Mbembe, África Insubmissa, p. 24.

${ }^{231}$ Idem, op. cit. p. 28.
} 
missionação pacífica ${ }^{232}$ - empregavam formas de coerção física e simbólica no processo de conversão. Independente da ordem católica, os missionários eram portadores de um programa reformador que:

\begin{abstract}
Visava reordenar o tempo e o quotidiano dos indivíduos e das comunidades, não apenas em torno de uma rigorosa pedagogia dos sacramentos, mas, de igual modo, da veiculação de um conjunto de normas de vida, padrões de conduta, modos de existência que deviam impor-se sobre a forma bárbara, desgraçada e silvestre que pautava a vida dos africanos. Tal como ocorria nos campos e cidades da Europa, o projeto missionário comportava uma dimensão dupla, confessional e civil, cujas componentes mantinham entre si uma relação indissolúvel, quase inextrincável, mas sempre presente em todas as acções e iniciativas dos religiosos ${ }^{233}$.
\end{abstract}

Almeida percebe também que esse processo, de regulação cotidiana dos hábitos, fora gradualmente assimilado pela aristocracia congolesa. Notadamente através de várias escolas, cuja mais expressiva, em 1548, era a do jesuíta Diego de Soveral, mantida e apoiada pelo mani Kongo ${ }^{234}$. Além disso, o sacramento do batismo e a disputa entre as diferentes chefaturas por recebimento desse título ${ }^{235}$ demonstravam como a “vontade de comunhão da fé cristã, afirma, ao mesmo tempo, um desejo de assimilação ao modelo de vida europeu” ${ }^{236}$. É conveniente perceber como essa análise tem raízes na teoria de Elias sobre os processos de formação do conceito de civilização e cultura na Europa dos séculos XV ao XVIII. Para Elias, essa "consciência de superioridade” foi utilizada como instrumento das nações europeias e das classes superiores dos segmentos não-europeus nas colônias, como “justificativa do seu domínio”237.

\footnotetext{
${ }^{232}$ Thornton, The Development of an African Catholic Church, p. 153-155.

${ }^{233}$ Almeida, Uma Infelicidade Feliz, p. 646

${ }^{234}$ Almeida, Uma Infelicidade Feliz, p. 648.

${ }^{235}$ Almeida destaca o caso do batismo de Songa no século XVI, um soba que governava uma região ao longo do rio Kuanza. A notícia recebida no Ndongo motivou outros senhores a expressarem sua vontade pelo sacramento. Ver: Idem, op. cit, p. 660-661.

${ }^{236}$ Idem, op. cit., p. 647.

${ }^{237}$ Elias, Processo Civilizador I, p. 64.
} 
Mas, para além da descrição de como se dava a apropriação da cultura material ou simbólica europeia pelas classes superiores congolesas e angolanas, Almeida buscou fontes que lhe fornecessem informações sobre os métodos utilizados na missionação, revelando as formas coercitivas e violentas na difusão do cristianismo. Nesse caso, os capuchinhos foram os emissários máximos de uma conduta ascética e de uma pedagogia brutal da civilidade. Uma das situações encontradas por ele foi registrada pelo capuchinho GirolamoMerolla da Sorrento por volta de 1680. Na ocasião, o padre, ao receber uma mãe que solicitava o batismo de seu filho pequeno, percebe que a criança carregava, no pescoço, um colar colorido com sementes de árvore. Merolla já havia sido alertado dessa prática, porém, decidiu aplicar-lhe um corretivo solicitando ao escravo da missão que arrancasse da criança o colar e aplicasse na mulher um determinado número de açoitadas. Durante o castigo a mulher pedia o perdão dizendo ter colocado não um, mas quatro colares para proteger o filho durante o caminho até a missão ${ }^{238}$. Nesse episódio, por exemplo, Almeida identifica situações que dizem tanto sobre a atividade missionária na região, quanto sobre a forma como as populações lidavam com diversas cosmovisões.

Carlos Almeida ratificou, além disso, que a escravatura foi instrumento fundamental na manutenção das missões, seja no discurso, seja na prática. Ela era vista e exaltada como recurso de salvação. Tanto para as missões jesuítas, envolvidos diretamente no comércio de escravizados no interior, quanto para as missões capuchinhas a manutenção das ordens nessas regiões só existia mediante o sistema do cativeiro. Os serviços variavam do trabalho agrícola ao carregamento de materiais dos padres, passando pela coerção das práticas mágicas. Almeida apresenta, através do rico detalhamento do padre Marcellino d’Atri, que os cativos moradores do hospício capuchinho de Nkusu passavam as centenas e que muitas vezes os

\footnotetext{
${ }^{238}$ Almeida, Uma Infelicidade Feliz, p 711.
} 
escravizados oferecidos aos padres eram vendidos para o comércio atlântico visando a manutenção das missões ${ }^{239}$.

Esse conjunto de práticas, no entanto, são diretamente ligadas às formações discursivas da alteridade. V.Y. Mudimbe avalia, por exemplo, as pinturas de Hans Burgkmair e as xilogravuras de FelippoPigafetta e considera que nelas existem duas atividades representadas:

de um lado, sinais de uma ordem epistemológica que, silenciosa mas imperiosamente, indicam os processos de integração e diferenciação das figuras no âmbito da igualdade normativa; por outro lado, a excelência de uma pintura exótica que cria uma distância cultural, graças a uma acumulação de diferenças acidentais, nomeadamente, a nudez, a negrura, o cabelo encarapinhado, as braceletes e os fios de pérolas $^{240}$.

Almeida parte dessas considerações de Mudimbe lendo os registros missionários na ordem dos discursos de um saber-poder. Ele percebe que o discurso sobre a ordem natural do local tinha diretas relações com as visões sobre as condutas humanas. O que porventura poderia ser desprezado como parte desnecessária das descrições é no fundo a forma com que esses missionários lidavam com as populações. Entre os missionários capuchinhos ele inscreve Giovanni Cavazzi como o “máximo expoente deste modelo de abordagem à realidade natural”241. O seu mundo estava organizado numa gramática complexa, indistinguível entre normas de comportamento, ordem do mundo natural e fé. Para Almeida, quando o missionário narra no Livro I de Istoricadescrizione... o comportamento da natureza vivaz e exagerada está informando aos seus leitores todo um conjunto de seres que dela fazem parte. Ao transportarem, por exemplo, flora e faunas europeias para aqueles locais,Cavazzi informava que elas reagiam de forma inesperada: videiras que vicejam duas vezes por ano,

\footnotetext{
${ }^{239}$ Idem, op. cit., p. 791.

${ }^{240}$ Mudimbe, A Invenção de África, p. 24.

${ }^{241}$ Almeida, Uma Infelicidade Feliz, p. 239.
} 
mas seu fruto nunca amadurece; o trigo que, ao invés de amadurecer, cresce como erva alta. E assim, "na hora de semear a palavra naquelas terras silvestres o missionário enfrentava essa realidade armado [...]" ${ }^{242}$.

Nesses discursos, onde a classificação sobre a vida das populações se confundia com a ordem natural, Almeida encontra um exemplo no Livro II de Istoricadescrizione... e no primeiro livro do volume A do Manuscrito Araldi de Cavzzi. Inclusive, neste último documento com o título “Dell’intabilitá, \& pouca fermezadella gente negra diquesta misera Ethiopiainteriore”, ele destaca a metáfora naturalista que compara o espírito africano à cana com aparência exterior de fortaleza, mas que por dentro se revelava vazia e fraca ${ }^{243}$. Desse modo, toda a "exegese em torno da inconstância do africano resumia-se afinal numa advertência de caráter metodológico dirigida aos missionários que, no fundo, viessem a desenvolver a sua actividade naqueles lugares”244.

Além disso, ele aponta nos discursos missionários a exaltação da presença secular europeia na erradicação das práticas bárbaras. Ao exigirem a monogamia, os hábitos à mesa e outras atividades cotidianas, a influência civil prestava às populações uma transformação que também era entendida como sinal de salvação, cuja reforma dos hábitos e costumes afastava a pessoa africana da barbárie e da situação infeliz que se encontrava ${ }^{245}$.

Por fim, Almeida entende o evangelizar naqueles lugares além da difusão da fé, atribuindo um peso significativo na ação impositiva missionária e nas formas de resistência das populações, aí se diferenciando significativamente de Thornton. Para ele, catequizar era também uma forma de promover um comportamento civil de contrição das pulsões, de moderação das vontades, do governar-se por leis razoáveis, do refinar de gestos, do incrementar do gosto musical europeu e do abster-se de impulsos sensuais, ou seja, "civil e

\footnotetext{
${ }^{242}$ Idem, op. cit., pp. 262-314.

243 Idem, op. cit., p 551.

${ }^{244}$ Almeida, A narrativa etnográfica, p. 20.

${ }^{245}$ Idem,Uma Infelicidade Feliz, pp. 707-710.
} 
cristão são duas faces inseparáveis de uma mesma condição, um não existe sem o outro, cada um é função do outro”246. Mais ainda, questiona até que ponto as traduções dos missionários sobre a inconstância e mutabilidade do espírito africano - utilizadas como justificava nos métodos coercivos aplicados na conversão -não representava na verdade um indício da solidez e plasticidade das estratégias cosmológicas ao se apropriarem seletivamente de rituais cristãos implicando-lhe novos significados.

O eurocentrismo incômodo dos registros missionários, que deveria ser excluído em detrimento de uma suposta objetividade numa manobra de distanciamento do Eu para se tornar o Outro, apresenta-se como revelador das relações e dos processos endógenos no estabelecimento da hegemonia. Assim:

[...] a literatura missionária adquire novos sentidos, que dizem tanto sobre 0 modo como as sociedades africanas responderam, criativamente, à proposta evangelizadora, como sobre os processos de estruturação, na Europa, de um discurso sobre a diferença cultural que conformaria, de forma impressiva e duradoura, o olhar sobre o outro e a diferença cultural $^{247}$.

Apesar disso, a disputa pela melhor metodologia aplicável ao estudo da história congolesa nos revela também uma disputa para quem melhor define a alteridade. Às vezes com aparatos teóricos que nada tem a ver com a filosofia africana mas que pretendem dizer sobre sua “estrutura mental” (Thornton). Em outros momentos com a instrumentalização dos filósofos africanos para legitimar o conhecimento não-africano sobre África - talvez seja o caso de Carlos Almeida quando ele utiliza pontualmente as teorias de Valentim Mudimbe. Jean-GodefroyBidima identifica nessas posturas uma forma de pensar os estudos africanos que opera da seguinte maneira: "Se os outros que nós queremos estudar são como nós, então lhes ensinemos o que eles não sabem deles mesmo, ou, então, se os outros não são como nós,

\footnotetext{
${ }^{246}$ Idem, op. cit., p. 818.

${ }^{247}$ Almeida, A narrativa etnográfica, p. 29.
} 
então escrevamos um romance para nossas populações sobre eles”248. Nesse aspecto instrumental, as figuras do historiador ou etnólogo e o filósofo africano se encontram hoje num nível de interdependência acadêmica que reafirma sempre a posição de uma “epistemologia do Norte”249, enquanto o filósofo africano, pela falta de credibilidade que as demais culturas lhe atribuem, “apostará no etnólogo que defenderá seus pontos de vista nos colóquios e colunas” ${ }^{250}$. Por sua vez, o historiógrafo ou etnólogo “precisa do filósofo africano para ser ao menos especialista em filosofia...africana”251.

\section{CONSIDERAÇÕES FINAIS}

Como vimos, as práticas e discursos em relação aos conhecimentos sobre África possuem uma história própria imiscuída nas histórias de África. Aliás, “todo ato linguístico pode produzir efeitos ilocucionários pelos quais a mudança de comportamentos dos interlocutores se opera” ${ }^{252}$. Ou seja, discursos e práticas atuam de maneira simultânea na construção dos saberes africanos e sobre África. Reavaliando os caminhos percorridos nessa pesquisa percebemos três eixos estruturantes nos quais se operam esses saberes: a) através de aparatos acadêmico-burocráticos; b) por meio da relação tempo e espaço; e, por fim, c) através da linguagem ${ }^{253}$.

No século XX, os aparatos acadêmico-burocráticos com a crescente especialização das disciplinasreforçaeam o poder de quem teria a autoridade para delimitar quem é o Outro e

\footnotetext{
${ }^{248}$ Bidima, Da Travessia, Contar Experiências, Partilhar o Sentido, pp. 8-9.

${ }^{249}$ Santos, Conhecimento e transformação social: para uma ecologia dos saberes, p. 177.

${ }^{250}$ Bidima, op. cit., p. 9.

${ }^{251}$ Idem, op. cit., p. 10.

${ }^{252}$ Bidima, Da Travesseia Contar Experiências, Partilhar o Sentido, p. 4.

${ }^{253}$ Esses eixos foram pensados a partir do artigo Do mal-estar acadêmico: uma conversa sobre a colonialidade e resistências, produzido pelo GEAC (Grupo de Estudos em Antropologia Crítica).
} 
o que ele poderia vir a ser. É bem verdade que a partir dos movimentos de libertação em África essas lógicas passam a ser questionadas, mesmo sobre as bases da epistemologia que as legitimavam. Vimos, por exemplo, que a definição acadêmica da antropologia e da história estruturaram e limitaram as possibilidades de ser humano e ser histórico. E, mesmo nas suas fases mais "revisionistas”, essas duas ciências se perpetuavam como saberes coloniais. Na estrutura acadêmica, os primeiros centros de estudos sobre África serviam aos interesses das nações europeias. Foram criados, construídos e pensados por e para a Europa. Ao mesmo tempo, essa estrutura acadêmica cria referenciais e autoriza sempre a partir de seus centros, ou seja, são validados os estudos que seguem os autores "canonizados”, quase sempre de origem no norte do globo. Pensemos, por exemplo, que todo aparato acadêmico construído pelos Annales com Braudel - naquilo que tange sua estrutura material com financiamentos da Fundação Rockfeller e uma vasta teia de influências - estabeleceu, para uma geração de historiadores das décadas de 1960 e 1970, quais deveriam ser os fundamentos para a escrita de uma obra histórica.

Depois, tratou-se de aplicar um julgamento às produções acadêmicas africanas que, ou as excluía por completo ou as incluía no sentido de que elas contribuem com o pensamento essencialmente africano. Essa postura se relaciona com as noções de tempo e espaço. A ideia de não coetaneidade na relação opositiva África/Ocidente atuou em duas frentes: i) como função reguladora na proposição da necessidade de desenvolvimento do continente, uma obra sempre inacabada clamando pelo progresso; ii) por seu tempo ser sempre outro e estacionado, seus saberes contemporâneos também são expressões dos saberes tradicionais, antiguíssimos e imutáveis. Isso justifica não só a ausência das produções acadêmicas, mas também a sua inclusão apenas como forma de legitimar os saberes produzidos.

Por fim, a linguagem acadêmica operou decisivamente na construção desses saberes sobre África pois, aqueles que não se enquadram nessa linguagem são rapidamente colocados 
à margem. A linguagem acadêmica olha para a África, mas não a vê. E, uma vez que o poder colonial consiste em “[...] ver ou não ver, de ser indiferente, de tornar invisível aquilo que não podemos ver”, aqueles que não são vistos ou escutados não podem existir ou falar por si só. Logo, "é preciso que outra pessoa fale em seu nome e no seu lugar, para que o que ele pretende dizer faça completamente sentido em nossa língua” ${ }^{254}$. Repetidas vezes encontramos exemplos durante o trabalho de uma operação onde os estudiosos pressupunham a aproximação total (um tipo de fusão) com o Outro, de modo a tornar-se eles mesmos a voz de seus “objetos”. Nessa operação linguística, a autoridade é conferida pelo princípio do conhecimento do real $^{255}$. Mas, além disso, vemos constantemente outras formas de reivindicação de autoridade sobre o conhecimento através da linguagem acadêmica que flertam com a antiética profissional. Recentemente, por exemplo, um embate entre Paul Lovejoy e João José Reis evidenciou esse tipo de reivindicação. No artigo Jihad na África Ocidental durante a "Era das Revoluções": em direção a um diálogo com Eric Hobsbawm e Eugene Genovese, publicado em 2014 na revista Topoi, Lovejoy trata das relações entre os movimentos ocorridos na África Ocidental no final XVIII e início do XIX e os acontecimentos no mundo atlântico. No entanto, ele coloca o nome de José Reis entre os historiadores que não levaram em consideração a influência desses movimentos africanos nos processos de resistência de escravizados nas Américas $^{256}$. Uma injustiça corrigida pelo próprio José Reis no artigo Resposta a Paul Lovejoy, apontando não só esse equívoco mastambém trechos plagiados de outro artigo seu aos quaisLovejoy não faz referências. Nas palavras de Reis:

A questão agora não é, como Lovejoy pretende, que eu desconheça a África dos malês ou deixe de interpretá-la como fator ponderável em

\footnotetext{
${ }^{254}$ Mbembe, Crítica da Razão Negra, p. 193.

${ }^{255}$ Cf. supra, p. 13; Mundimbe, A Ideia de África, p. 64.

${ }^{256}$ Lovejoy,Jihad na África Ocidental durante a "Era das Revoluções": em direção a um diálogo com Eric Hobsbawm e Eugene Genovese, p. 40.
} 
minha narrativa da revolta de 1835; o problema é seu desejo de se impor como a última palavra sobre o tema, não importa se para isso precise desobedecer procedimento elementar da crítica intelectual, que é reconhecer e expor honestamente os dados do oponente. ${ }^{257}$

Por outro lado, vimos também como essa linguagem está sempre em busca da forma mais adequada de interpretar as fontes e as relações que se deram entre africanos e europeus. Uma caçada da metodologia perfeita que evoca uma superioridade em relação à anterior num diálogo feito sempre no eixo global norte-norte. Ora com novas roupagens (como é no caso do uso das teorias pós-coloniais ou dos estudos africanos), outras vezes com uso dos referenciais teóricos já muito questionados por outros estudos.

É certo que essas três operações não são encontradas separadamente, elas se imbricam num conjunto de textos e práticas constitutivas do saber-poder. Aparatos acadêmico-burocráticos, relação de não coetaneidade de tempo-espaço e aplicação de uma linguagem acadêmica seleta são instrumentos complementares na perpetuação da lógica que autoriza e desautoriza.

Até mesmo se pensarmos numa autocrítica, os estudos em âmbito nacional estão inseridos de alguma forma nos meandros da constituição do saber-poder. No conjunto da academia brasileira poderíamos enquadrar esta e outras produções em um dos tipos de discursos acadêmicos descritos por Bidima: o do "discurso de fundo comunitarista”. Ou seja, aquele que quando orientado pelas políticas de cotas acaba adotando uma relação instrumental com a filosofia africana onde o estudante negro brasileiro "precisa do filósofo africano para que esse lhe conte o romance de suas origens. O filósofo africano se torna assim o termômetro que, a cada vez, irá medir sua africanidade”258.

Mas afinal, como pensar os caminhos percorridos por África sem recair nessas operações que são sutis e potentes? Tudo dependerá da reflexão do próprio estudioso em

\footnotetext{
${ }^{257}$ Reis, Resposta a Paul Lovejoy, p. 377

${ }^{258}$ Bidima, Da Travesseia Contar Experiências, Partilhar o Sentido, p. 10.
} 
relação a sua posição no mundo para que não se pretenda confundir ele mesmo com o seu “objeto”. Além do mais, é preciso saber “repartir o peso da história”259 em partes iguais, abrindo-se para a "partilha do comum da abertura para o mundo" ${ }^{260}$, onde múltiplas ancestralidades possam compartilhar suas próprias vozes sem se sobreporem umas às outras. Só assim, talvez, ainda haja espaço para a produção do novo por aqueles que são tidos como uma humanidade a parte. É preciso dar e abrir espaço para múltiplas vozes onde o que "partilhamos em conjunto sejam as diferenças"261.

\section{REFERÊNCIAS BIBLIOGRAFICAS}

ALMEIDA, Carlos J. D. Uma Infelicidade Feliz: A Imagem de África e dos Africanos na Literatura Missionária sobre o Kongo e a região mbundu. Lisboa: Universidade Nova de Lisboa, Tese de Doutorado, 2009.

— “ “A narrativa etnográfica na literatura missionária sobre o Kongo, séculos XVI a XVIII”. In.: S. Pantoja \& E. C. Thompson (1 ${ }^{\mathrm{a} e d}$.), Em torno de Angola: narrativas, identidades e as conexões atlânticas, São Paulo: Intermeios, pp. 15-32, 2014.

APPIAH, Kwame Anthony. Na casa de meu pai. Rio de Janeiro: Contraponto, 1997.

\footnotetext{
${ }^{259}$ Mbembe, op. cit., p. 296.

${ }^{260}$ Idem, ibid.

${ }^{261}$ Idem, op. cit. 297
} 
ALENCASTRO, Luiz Felipe de. O Trato dos Viventes: formação do Brasil no Atlântico Sul. São Paulo: Companhia das Lestras, 2000.

BARBOSA, M. A África por ela mesma: a perspectiva africana na História Geral da África (UNESCO). São Paulo, 2012. Tese (Doutorado em História) - Faculdade de Filosofia e Ciências Humanas, Universidade de São Paulo.

BATSÎKAMA, Parício. Lûmbu: a democracia no antigo Kôngo. Luanda: Mediapress, 2013. O Reino do Kôngo e sua Origem Meridional. Luanda: Universidade Editora, 2011. As Origens do Reino do Kôngo. Luanda: Mayamba Editora, 2010.

BIRMINGHAM, David. The Portuguese Conquest of Angola.Londres: Oxford University Press, 1965.

Trade and Conflict in Angola: The Mbundu and Their NeighboursUnder the Influence of the Portuguese 1483-1790. Oxford: Clarendon Press, 1966.

BOCAGE, M. M. Barbosa du. Poesias. $3^{\text {a }}$ ed. Lisboa: Sá da Costa, 1956.

BRAUDEL, F. “Les Espagnols et l’Afrique du Nord”. RevueAfricane, v. 69, 1928. Escritos Sobre a História. São Paulo: Editora Perspectiva, 1992. 
BURKE, P. A Revolução Francesa da Historiografia: A escola dos Annales (1929-1989). São Paulo: Editora UNESP, 1992.

CHARTIER, Roger. A história cultural: entre práticas e representações. Lisboa: Difel, 2002.

CRUMMELL, A.The Future of Africa. New York: Charles Scribner, 1862.

DELACROIX, Christian; DOSSE, François \& GARCIA, Patrick. (2012), As Correntes Históricas na França: séculos XIX e XX. Rio de Janeiro: Editora FGV.

DIFUILA, Manuel Maria. “Historiografia da História de África”. In.:Actas do Colóquio Construção e Ensino da História da África. Lisboa: Linopazas, pp. 51-56. 1995.

ELIAS, Norbert. Os Estabelecido e os Outsiders: sociologia das relações de poder a partir de uma pequena comunidade. Rio de Janeiro: Jorge Zahar, 2000.

O Processo Civilizador: uma história dos costumes. $1^{\circ}$.vol. Rio de Janeiro: Jorge Zahar, 1994.

O Processo Civilizacional: invegaçõessociogenéticas e psicogenéticas. $2^{\circ}$.vol. Lisboa: Don Quixote, 1990.

FALOLA, Toyin; JENNINGS, Christian.Sources and Methods in African History: Spoken, written, unearthed. New York: The University of Rochester Press, 2004. 
FANON, Frantz. Pele NegraMáscarasBrancas. Salvaor: EDUFBA, 2008.

GAILLARD, Jacques. “The Senegalese scientific community: africanization, dependence and crisis” in: Jacques Gaillard, V.V. Krishna \& Roland Waast (eds.). Scientific communities in the developing world.New Delhi, Thousand Oaks, London: Sage Publications, 1997.

GONÇALVES, Rosana Andréa. África indômita: Missionários capuchinhos no Reino do Congo (século XVII). São Paulo: Universidade de São Paulo, Dissertação de Mestrado, 2008.

GILROY, Paul. O Atlântico Negro: modernidade e dupla consciência. Rio de Janeiro: UCAM, editora 34, 2001.

. Entrecampos, Nações, Culturas e o Fascínio da Raça. 1. ed. São Paulo: Annablume, 2007.

HEGEL, G. W. F. Lecciones Sobre la Filosofia de La Historia Universal. Tomo I, Boenos Aires: Revista de Occidente Argentina, 1946.

HENRIQUES, Isabel de Castro. Os pilares da diferença: relações Portugual-África, séculos XV-XIX. Lisboa: Celeidoscópio, 2004.

. “A História da África e a reconstrução da visão do Outro”. in: II Semana Sociológica O lugar e o papel das Ciências Sociais e Humanas na Modernização de Portugal Contemporâneo. Lisboa: UniversidadeAutônoma, 1990. 
HEYWOOD, Linda M. \& THORNTON, John k. Central Africans, Atlantic Creoles, and the Foundations of the Americans, 1585-1660. Nova York: Cambridge University Press, 2007.

HILTON, Anne. The Kingdom of Kongo. Oxford: Calereson Press, 1985.

HILTON, Anne. "European Sources for the Study of Religious Change in Sixteenth and Seventeenth Century Kongo”. in: Paideuma33, 1987.

HORTA, José da Silva. “Entre história europeia e história africana, um objecti de charneura: as representações”.in:Actas do colóquio Contrução e Ensino da História da África. Lisboa: Fundação CalousteGulbenkian, pp. 189-200, 1994.

KOSELLECK, Reinhart. Futuro passado: Contribuição à semântica dos tempos históricos. Rio de Janeiro: Contraponto/PUC-RJ, 2006.

LABOURET, H. \& SAYOUS, A. E. “Questions Africanes”.in:Annales d'histoire économique et sociale, 9, 1931.

LOPES, Carlos. “A Pirâmide Invertida: historiografia feita por africanos”. in: Actas do Colóquio Construção e ensino da história da África. Lisboa: Linopazes, pp. 21-29, 1995.

LOVEJOY, P. E. Transformation in slavery. Londres: Cambridge University Press, 1983.

LOVEJOY, Paul \& LAW, Robin.The Biography of MahommadBaquaqua: his passage from slavery to freedom in África and América. Princeton: Marcus WeinerPublishers, 2003. 
. “Jihad na África Ocidental durante a "Era das Revoluções”: em direção a um diálogo com Eric Hobsbawm e Eugene Genovese”. in: Topoi Revista de História, 15, 2014.

LÖWITH, Karl. Meaning in History: The Theological Implications of the Philosophy of History. Chicago: University of Chicago Press, 1957.

MBEMBE, Achille. Crítica da RazãoNegra.Lisboa: Antígona, 2014. . África Insubmissa: Cristianismo, poder e Estado na sociedade pós-colonial. Luanda: Edições Pedago; Edições Mulemba, 2013.

“As Formas Africanas de Auto-Inscrição”. in:Estudos Afro-Asiáticos, 23, 2001.

MILLER, Joseph C. "History and Africa/Africa and History”. in:The American Hitorical Review, 104,1999.

__ "Requiem for the 'Jagas’”.in: Cahiers d'étudesafricaines, 13, 1973.

MOSES, W. J. Alexander Crummell A Study of Civilization and Discontent.New York: Oxford University Press, 1989.

MUDIMBE, Valentin Y. A Ideia de África. Luanda: Ed. Pedago\&Mulemba, 2013. . A Invensão de África. Luanda: EdiçõesPedago; Edições Mulemba, 2013. 
OLIVA, Anderson. Lições Sobre a África: dialogos entre as representações dos africanos no imaginário Ocidental e o ensino de história da África no Mundo Atlântico (1990-2005). Brasília: Universidade de Brasília, Tese de Doutorado, 2007.

. “Da Aethiopia à África: Ideias de África, do Medievo Europeu à Idade Moderna”. In.: Fênix - Revista de História e Estudos Culturais, 5, 2008.

OLIVEIRA, Ingrid Silva de.O Olhar de um capuchinho sobre a África do século XVII: A Construção do Discurso de Giovanni AntonioCavazzi. Rio de Janeiro: Universidade Federal Rural do Rio de Janeiro, Dissertação de mestrado, 2011.

PRATT, Mary Louise. Ojos Imperiales: literatura de viajes y transculturación. Ciudad de México: Fondo de Cultura Económica, 2010.

POPPER, Karl. The Poverty of Historicism. London: Routledge and Kegan Paul, 1957.

RATELBAND, Klass. Os Holandeses no Brasil e na Costa Africana: Angola, Kongo e S. Tomé (1600-1650). Lisboa: Vega, 2003.

REINHARDT, Bruno. "Poder, história e coetaneidade: os lugares do colonialismo na antropologia sobre a África”.in:Revista de Antropologia da Universidade de São Paulo, 57, 2014.

REIS, João José. “Resposta a Paul Lovejoy”. in: Topoi Revista de História,16, 2015.

RÜSEN, Jörn. “Narratividade e Objetividade nas Ciências Históricas”. in: Textos de História, 4, 1996. 
SADE, M. de. A Filosofia na Alcova, ou, Os Preceitos Imorais. São Paulo: Iluminuras, 2008.

SANTOS, Boaventura de S. Santos, "Conhecimento e transformação social: para uma ecologia dos saberes”. in: Somanlu - Revista de Estudos Amazônicos, 7, 2007.

SCHWARCZ, Lila Moritz. O Sol do Brasil: Nicolas-Antoine Taunay e as desventuras dos artistas franceses na corte de d. João. São Paulo: Companhia das Letras, 2008.

SWEET, James. Recriar África: cultura, parentesco e religião no mundo afro-português (1441-1770). Lisboa: Edições 70, 2007.

SUBRAHMANYAM, Sanjay. “Connected Histories: Notes towards a reconfiguration of Early Modern Eurasia”. in: Modern Asian Studies, 31, 1997.

THORNTON, John K. A África e os Africanos na Formação do Mundo Atlântico (14001800). Rio de Janeiro: Campus, 2003.

THORNTON, John K. “Cavazzi, Missione Evangelica” in:African American Studies, Disponível em http://www.bu.edu/afam/faculty/john-thornton/cavazzi-missione-evangelica2/, [consultado em 31-10-2014].

.A África e os Africanos na Formação do Mundo Atlântico (1400-1800). Rio de Janeiro: Campus, 2003.

. The Kongolese Saint Anthony: Dona Beatriz Kimpa Vita and the Antonian Movement, 1684-1706. New York: Cambridge University Press, 1998.

The Kingdom of Kongo: Civil War and Transition 1641-1718. Madison: University of Wisconsin Press, 1983. 
“New Light on Cavazzi’s Seventeenth-Century Descripition of Kongo”.in: History in Africa, 6, 1979.

VANSINA, Jan.Oral Tradition: A Study in Historical Methodology. Londre: Routledge \& Kegan Paul, 1965.

. Kingdoms of the Savana. Wisconsin: Wisconsin Press: 1966.

Oral Tradition as History. Wisconsin: Wisconsin Press, 1985.

. Living with Africa. Wisconsin: Wisconsin Press, 1994.

. “An Interview with Jan Vansina”.in: The American Society for Ethnohistory, 42, 1995.

VIEIRA, Rui Aballe. “O Império que Nunca Existiu: O Expansionismo oportunista de Franco”. in: Revista de Ralações Internacionais da Universidade Nova de Lisboa, 28, 2010. 